\title{
Mercury and Methylmercury in Reservoirs in Indiana
}

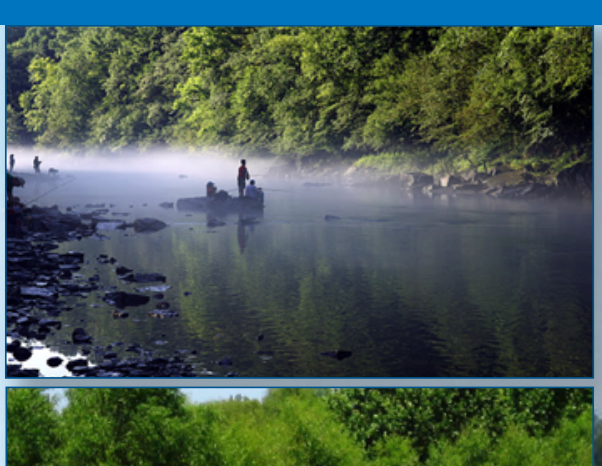

Professional Paper 1813

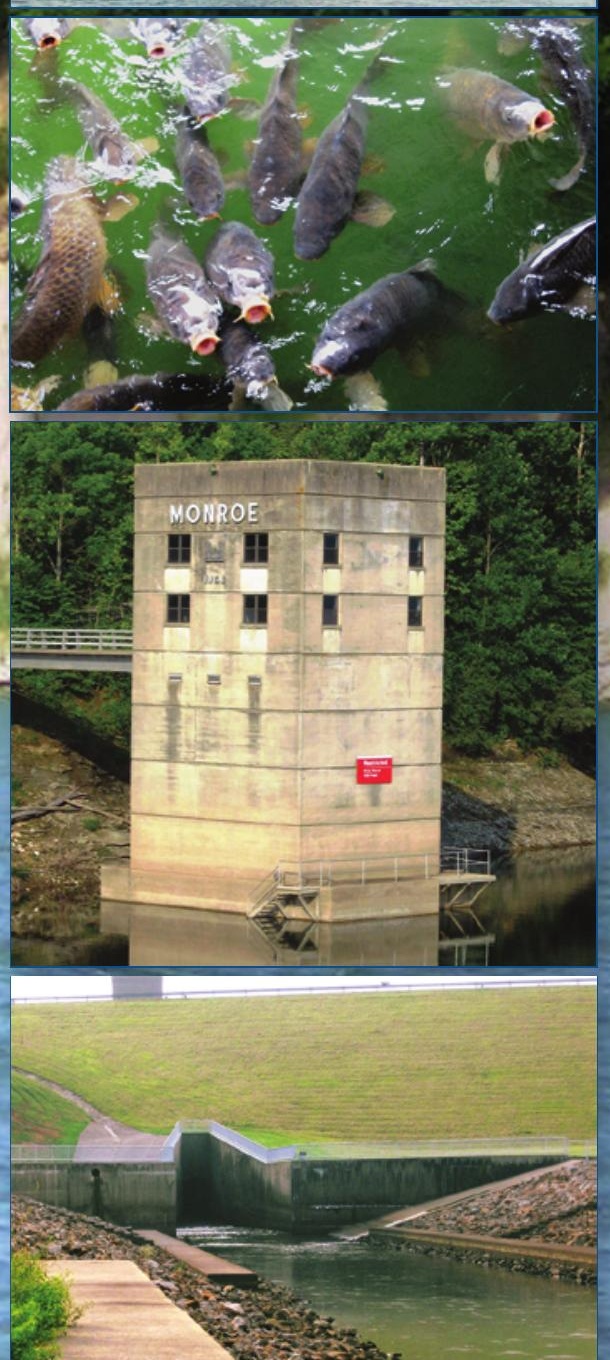

U.S. Department of the Interior U.S. Geological Survey 


\section{Cover Photos}

Background. Shoreline near Hanna Creek Marina at Brookville Lake, Indiana (photograph by Amanda L. Fredericksen, USGS).

Insets from top to bottom.

People fishing unnamed stream (from U.S. Fish and Wildlife Service Image Library, http://digitalmedia.fws.gov/).

Great blue heron in Brookville Lake headwaters near Quakertown Recreation Area, Indiana (photograph by Martin R. Risch, USGS).

Boats moored at Fairfax Marina on Monroe Lake, Indiana (photograph by Martin R. Risch, USGS).

Common carp near Newton Stewart Marina at Patoka Lake, Indiana (photograph by Martin R. Risch, USGS).

Control tower at Monroe Lake dam near Harrodsburg, Indiana (photograph by Martin R. Risch, USGS).

Tailwater at Patoka Lake dam near Cuzco, Indiana (photograph by Martin R. Risch, USGS). 


\section{Mercury and Methylmercury in Reservoirs in Indiana}

By Martin R. Risch and Amanda L. Fredericksen

Professional Paper 1813

U.S. Department of the Interior

U.S. Geological Survey 


\title{
U.S. Department of the Interior SALLY JEWELL, Secretary
}

\section{U.S. Geological Survey \\ Suzette M. Kimball, Acting Director}

\author{
U.S. Geological Survey, Reston, Virginia: 2015
}

For more information on the USGS - the Federal source for science about the Earth, its natural and living resources, natural hazards, and the environment—visit http://www.usgs.gov or call 1-888-ASK-USGS.

For an overview of USGS information products, including maps, imagery, and publications, visit http://www.usgs.gov/ pubprod/.

Any use of trade, firm, or product names is for descriptive purposes only and does not imply endorsement by the U.S. Government.

Although this information product, for the most part, is in the public domain, it also may contain copyrighted materials as noted in the text. Permission to reproduce copyrighted items must be secured from the copyright owner.

Suggested citation:

Risch, M.R., and Fredericksen, A.L., 2015, Mercury and methylmercury in reservoirs in Indiana: U.S. Geological Survey Professional Paper 1813, 57 p., http://dx.doi.org/10.3133/pp1813.

ISSN 2330-7102 (online 


\section{Preface}

Scientists and health officials agree that mercury is a chemical of concern because relatively small amounts of a form of mercury known as methylmercury can accumulate in the food webs of ecosystems and pose risks to humans and wildlife. Most of the United States, including Indiana, has public health advisories about eating wild-caught fish because of mercury contamination. Mercury is a worldwide contaminant, meaning that freshwater and ocean fish bought at a grocery or restaurant may contain small but significant amounts of mercury and have a health advisory. It is important to understand that the highest risks from methylmercury in fish are for the unborn and young, but adults also can be severely affected. These health risks hold true for wildlife as well as for humans - and although humans can lower their risks by selecting the type and amount of fish they eat, wildlife cannot make such choices.

The story about mercury in the environment is complex. Most of the mercury in ecosystem food webs comes from the air, arriving in precipitation and dry fallout. Much of the mercury in the air comes from human activity, such as burning coal to make electricity, cement manufacturing, and steelmaking. Local and regional sources of mercury emissions to the air have been shown to influence mercury levels in local and regional ecosystems. Regulations to reduce mercury emissions to the air in the United States are based on the belief that methylmercury levels in ecosystem food webs will diminish in response, although the timing of this response is unknown and may vary among ecosystems.

Scientists have been studying mercury in the environment in Indiana since the 1990s. Mercury science requires highly specialized tools and techniques to properly quantify the small environmental concentrations that are important in ecosystems. By analyzing thousands of samples of wild fish, precipitation, stream and lake water, wastewater, air, and forest vegetation in Indiana, we have developed a framework for describing mercury occurrence, transport, and fate.

A previous retrospective study of mercury in Indiana watersheds used the natural boundaries of water movement to group and interpret the many pieces of mercury information. A finding from the study led to the research about mercury and methylmercury in Indiana reservoirs described in this paper. Reservoirs, unlike natural lakes, are a part of river systems that are managed for flood control, which leads to unintended effects on mercury transport and methylmercury formation. Reservoir dams slow the velocity of water, allowing particles carrying mercury to settle in the reservoir pools. In the summer especially, some of the mercury in the reservoir pools can be transformed to methylmercury, the toxic form of mercury that accumulates in food webs. Water flowing out of reservoirs tends to have substantially higher ratios of methylmercury to mercury than does water in free-flowing streams. Methylmercury levels in the water of the reservoirs are related to levels of mercury in the fish. Atmospheric mercury deposition, landscape factors, and water chemistry appear to affect the levels of mercury and methylmercury in reservoirs.

Knowledge of reservoirs in Indiana can provide a reference about the potential for methylmercury in other reservoirs of the Great Lakes and Ohio River Valley region. 



\section{Contents}

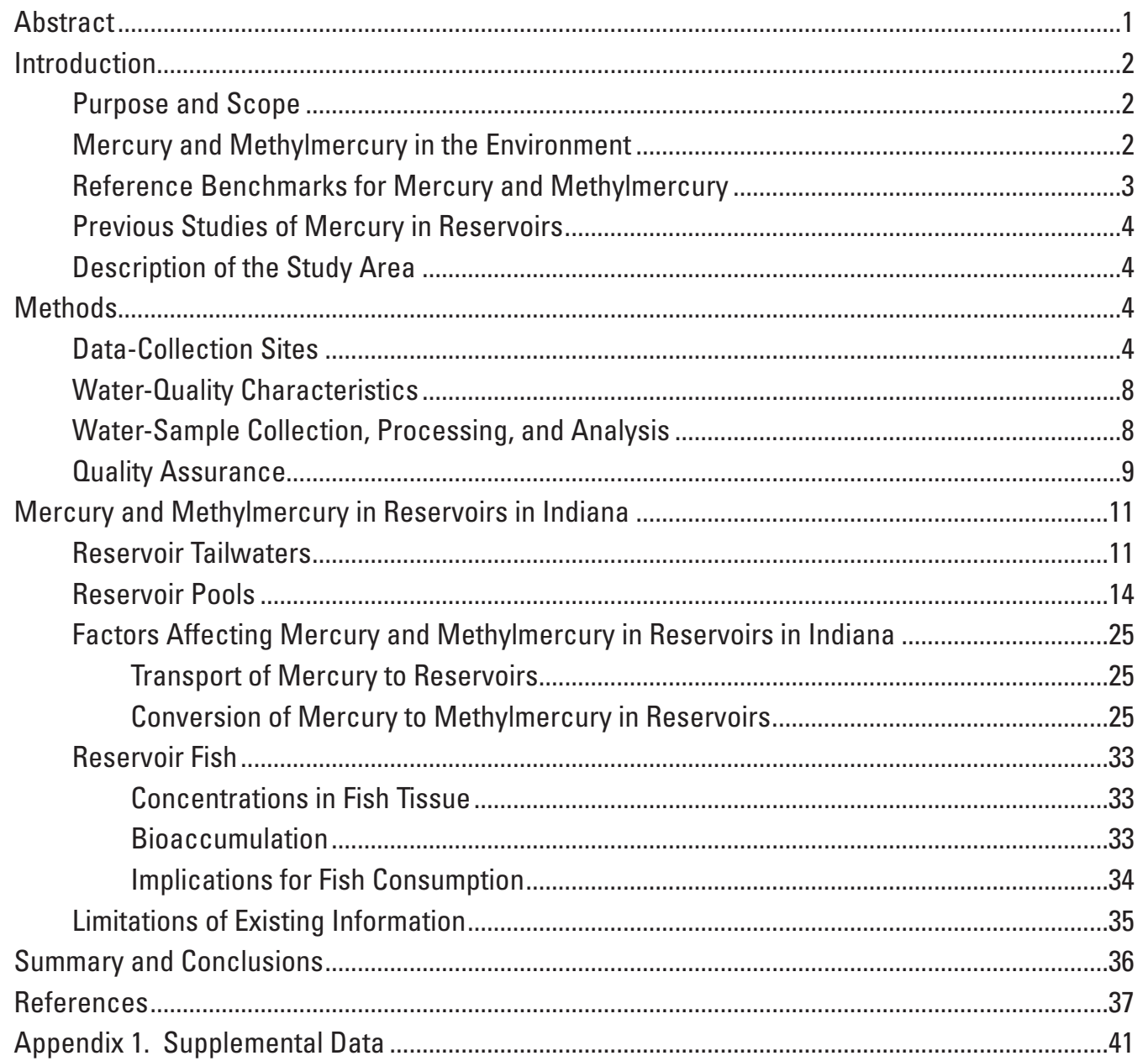

\section{Figures}

1. Flood-control reservoirs in Indiana

2. Generalized diagram of reservoir-pool-monitoring transect, water-quality verticals, and lake-bottom topography .....................................................................

3. Apparatus for collection of water samples for mercury analysis ......................................9

4. Mercury and methylmercury concentrations in water samples from tailwater

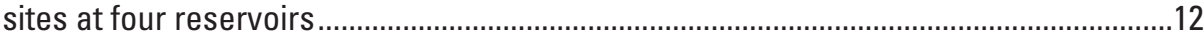

4. Mercury and methylmercury concentrations in water samples from tailwater sites at four reservoirs.............................................................................................13

5. Sampling sites and water-quality transects for Brookville Lake ....................................15

6. Sampling sites and water-quality transects for Monroe Lake........................................16

7. Sampling sites and water-quality transects for Patoka Lake ..........................................17

8. Whole-water mercury concentrations in water from Brookville Lake.............................20 


\section{Figures-continued}

9. Whole-water mercury concentrations in water from Monroe Lake ..............................21

10. Whole-water mercury concentrations in water from Patoka Lake ................................22

11. Ratio of dissolved methylmercury to mercury in water from Monroe Lake ....................23

12. Ratio of dissolved methylmercury to mercury in water from Patoka Lake ......................24

13. Relations between mercury and sample depth in Monroe Lake and Patoka Lake .........27

14. Distributions of mercury, methylmercury, dissolved oxygen, water $\mathrm{pH}$, and dissolved sulfate in Monroe Lake

15. Distributions of mercury, methylmercury, dissolved oxygen, water $\mathrm{pH}$, and dissolved sulfate in Patoka Lake..... .30

16. Areal extent of zone of high methylation potential in summer pool of Monroe Lake .....31

17. Areal extent of zone of high methylation potential in summer pool of Patoka Lake .......32

\section{Tables}

1. Selected information for flood-control reservoirs in Indiana ..........................................6

2. Reservoir-pool water-quality transect information.........................................................

3. Methods and reporting limits for determinations of water-quality characteristics..........8

4. Methods for analysis of mercury, particulate, and supplementary constituents

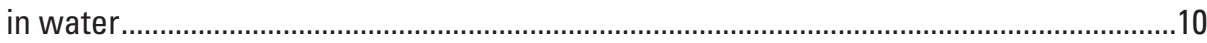

5. Mercury data summary for tailwaters at four reservoirs in Indiana .............................11

6. Reservoir-pool and tailwater sampling-site information .............................................18

7. Mercury data summary for pools and tailwaters at three reservoirs in Indiana.............19

8. Physiographic region, natural region, and surficial geology in the vicinity of reservoirs in Indiana .

9. Statistical correlations of reservoir pool mercury with sample depth and selected constituents in Monroe Lake and Patoka Lake.

10. Methylmercury bioaccumulation factors for five reservoirs in Indiana ..........................34

1-1. Reservoir-pool and tailwater mercury quality-control field blank sample data ..............42

1-2. Quality-control data for reservoir-pool and tailwater mercury field duplicate samples

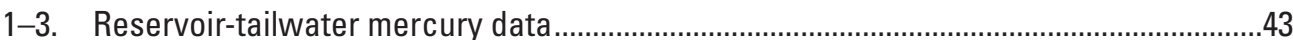

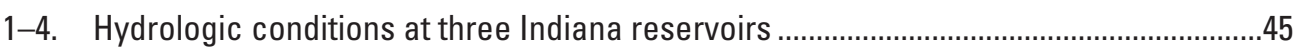

1-5. Reservoir-pool and tailwater data for mercury, water-quality characteristics,

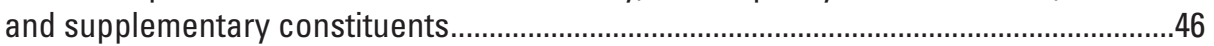

1-6. Percentages of land-cover categories in reservoir drainage areas ...............................50

1-7. Mercury wet- and dry-deposition rates and loads to reservoir watersheds in Indiana

1-8. Reservoir fish-tissue sample and mercury data. 


\section{Conversion Factors and Datums}

International System of Units to Inch/Pound

\begin{tabular}{lll}
\hline \multicolumn{1}{c}{ Multiply } & By & To obtain \\
\hline centimeter $(\mathrm{cm})$ & Length & \\
millimeter (mm) & 0.3937 & inch (in.) \\
meter $(\mathrm{m})$ & 0.03937 & inch (in.) \\
kilometer $(\mathrm{km})$ & 3.281 & foot (ft) \\
meter $(\mathrm{m})$ & 0.6214 & mile (mi) \\
\hline & 1.094 & yard (yd) \\
\hline square kilometer $\left(\mathrm{km}^{2}\right)$ & Area & square mile $\left(\mathrm{mi}^{2}\right)$ \\
\hline & 0.3861 & \\
\hline liter $(\mathrm{L})$ & Volume & quart (qt) \\
\hline & 1.057 & pound avoirdupois (lb) \\
\hline kilogram $(\mathrm{kg})$ & Mass & \\
\hline
\end{tabular}

Inch/Pound to International System of Units

\begin{tabular}{lcl}
\hline \multicolumn{1}{c}{ Multiply } & By & \multicolumn{1}{c}{ To obtain } \\
\hline inch (in.) & Length & \\
foot (ft) & 25.4 & millimeter $(\mathrm{mm})$ \\
mile (mi) & 0.3048 & meter $(\mathrm{m})$ \\
\hline & 1.609 & kilometer $(\mathrm{km})$ \\
\hline square mile $\left(\mathrm{mi}^{2}\right)$ & Area & \\
\hline
\end{tabular}

Temperature in degrees Celsius $\left({ }^{\circ} \mathrm{C}\right)$ may be converted to degrees Fahrenheit $\left({ }^{\circ} \mathrm{F}\right)$ as:

${ }^{\circ} \mathrm{F}=\left(1.8 \times{ }^{\circ} \mathrm{C}\right)+32$.

Temperature in degrees Fahrenheit $\left({ }^{\circ} \mathrm{F}\right)$ may be converted to degrees Celsius $\left({ }^{\circ} \mathrm{C}\right)$ as: ${ }^{\circ} \mathrm{C}=\left({ }^{\circ} \mathrm{F}-32\right) / 1.8$.

Vertical coordinate information is referenced to the National Geodetic Vertical Datum of 1929 (NGVD 29).

Horizontal coordinate information is referenced to the North American Datum of 1983 (NAD 83).

Elevation, as used in this report, refers to distance above the vertical datum.

Specific conductance is given in microsiemens per centimeter at 25 degrees Celsius $\left(\mu \mathrm{S} / \mathrm{cm}\right.$ at $\left.25^{\circ} \mathrm{C}\right)$.

Turbidity is given in nephelometric turbidity ratio units (NTRU).

Concentrations of chemical constituents in water are given in either milligram per liter (mg/L) or nanogram per liter ( $\mathrm{ng} / \mathrm{L})$.

Concentrations of chemical constituents in solids are given in either milligram per kilogram $(\mathrm{mg} / \mathrm{kg})$ or microgram per kilogram $(\mu \mathrm{g} / \mathrm{kg})$.

Atmospheric deposition is given in units of microgram per square meter $\left(\mu \mathrm{g} / \mathrm{m}^{2}\right)$.

A milligram is $0.001 \mathrm{gram}$. A microgram is 0.001 milligram. A nanogram is 0.001 microgram. 


\title{
Abbreviations
}

\author{
BAF bioaccumulation factor \\ DO dissolved oxygen \\ DOC dissolved organic carbon \\ EPA U.S. Environmental Protection Agency \\ GIS geographic information system \\ GPS global positioning system \\ $\mathrm{Hg} \quad$ mercury \\ IDEM Indiana Department of Environmental Management \\ $\mathrm{MeHg}$ methylmercury \\ NLCD National Land Cover Database \\ POC particulate organic carbon \\ RPD relative percent difference
}




\title{
Mercury and Methylmercury in Reservoirs in Indiana
}

\author{
By Martin R. Risch and Amanda L. Fredericksen
}

\section{Abstract}

Mercury $(\mathrm{Hg})$ is an element that occurs naturally, but evidence suggests that human activities have resulted in increased amounts being released to the atmosphere and land surface. When $\mathrm{Hg}$ is converted to methylmercury ( $\mathrm{MeHg}$ ) in aquatic ecosystems, MeHg accumulates and increases in the food web so that some fish contain levels which pose a health risk to humans and wildlife that consume these fish. Reservoirs, unlike natural lakes, are a part of river systems that are managed for flood control. Data compiled and interpreted for six flood-control reservoirs in Indiana showed a relation between $\mathrm{Hg}$ transport, $\mathrm{MeHg}$ formation in water, and $\mathrm{MeHg}$ in fish that was influenced by physical, chemical, and biological differences among the reservoirs. Existing information precludes a uniform comparison of $\mathrm{Hg}$ and $\mathrm{MeHg}$ in all reservoirs in the State, but factors and conditions were identified that can indicate where and when $\mathrm{Hg}$ and $\mathrm{MeHg}$ levels in reservoirs could be highest.

As part of a statewide monitoring network for $\mathrm{Hg}$ and $\mathrm{MeHg}$ in Indiana streams, 66 water samples were collected from four reservoir tailwater sites (downstream near the dams) on a quarterly schedule for 5 years. The reservoirs were Brookville Lake, Cagles Mill Lake, J. Edward Roush Lake, and Mississinewa Lake. Particulate-bound Hg concentrations were significantly lower in tailwater samples than in samples from free-flowing streams in the statewide network. (Free-flowing streams were not affected by dams and were not upstream from these reservoirs.) These data indicated the reduced flow velocity of water upstream from dams was allowing particulate-bound $\mathrm{Hg}$ to settle out of the water in the reservoir pools. The concentration ratios of $\mathrm{MeHg}$ to $\mathrm{Hg}$ were significantly higher in the tailwater samples than in samples from free-flowing streams, and the $\mathrm{MeHg}$ to $\mathrm{Hg}$ ratios were significantly higher in summer than in other seasons.

To evaluate the conditions related to $\mathrm{MeHg}$ formation, pools of three reservoirs (Brookville Lake, Monroe Lake, and Patoka Lake) were investigated during summer hydrologic conditions. Water temperature and dissolved oxygen were measured from the water surface to the lake bottom at 10 to 17 transects across each reservoir to identify three thermal strata, defined by water temperature, dissolved oxygen concentration, and depth. Depth-specific water samples were collected from these thermal strata throughout each reservoir, from the headwaters to the dam and from the tailwater. Mercury concentrations higher than 0.04 nanogram per liter (ng/L) were detected in all 53 samples, and $\mathrm{MeHg}$ concentrations higher than $0.04 \mathrm{ng} / \mathrm{L}$ were detected in 53 percent of the samples.

The investigation found a zone of water below 8 or 9 meters, with temperatures less than 18 degrees Celsius and dissolved oxygen less than 3.5 milligrams per liter, extending through nearly half the reservoir area in Monroe Lake and Patoka Lake. This zone had abundant dissolved $\mathrm{MeHg}$ and concentration ratios of dissolved $\mathrm{MeHg}$ to $\mathrm{Hg}$ that ranged from 25 to 82 percent. This zone also had water with $\mathrm{pH}$ less than 7 and decreased dissolved sulfate, conditions indicating sulfate reduction by microorganisms that promoted a high potential for the conversion of $\mathrm{Hg}$ to $\mathrm{MeHg}$. Reservoir outflow came from this zone at Monroe Lake and contributed to a tailwater concentration ratio for dissolved $\mathrm{MeHg}$ to $\mathrm{Hg}$ of 56 percent. Reservoir outflow at Patoka Lake was not from this zone, and dissolved $\mathrm{MeHg}$ was not detected in the tailwater. In contrast, samples from the summer pool at Brookville Lake had no $\mathrm{MeHg}$ detections even though $\mathrm{Hg}$ was detected, probably because the water $\mathrm{pH}$ higher than 7 inhibited sulfate reduction and did not promote the conversion of $\mathrm{Hg}$ to $\mathrm{MeHg}$.

Mercury and $\mathrm{MeHg}$ concentrations and the concentration ratios of $\mathrm{MeHg}$ to $\mathrm{Hg}$ in water varied among the six reservoirs in Indiana, and the differences were related to a combination of factors that could apply to other reservoirs. In areas with moderate to high rates of atmospheric $\mathrm{Hg}$ wet and dry deposition, $\mathrm{Hg}$ runoff and transport to streams and reservoirs was potentially highest for reservoirs with heavily forested watersheds in steep terrains of near-surface bedrock. Methylmercury concentrations and concentration ratios of $\mathrm{MeHg}$ to $\mathrm{Hg}$ were highest for reservoirs with the longest summer pools and highest inflow-to-outflow retention times, where waterchemistry conditions favoring sulfate reduction promoted conversion of $\mathrm{Hg}$ to $\mathrm{MeHg}$.

Methylmercury (reported as $\mathrm{Hg}$ ) in fish-tissue samples collected for the State fish consumption advisory program was used to describe $\mathrm{MeHg}$ food-web accumulation and magnification in the reservoirs. The highest percentages of fish-tissue samples with $\mathrm{Hg}$ concentrations that exceeded the criterion of 0.30 milligram per kilogram for protection of human health were from Monroe Lake (38 percent) and Patoka Lake (33 percent). A review of the number and size of fish species caught from these two reservoirs resulted in two implications 
for fish consumption by humans. First, the highest numbers of fish harvested for potential human consumption were species more likely to have $\mathrm{MeHg}$ concentrations lower than the human-health criterion (crappie, bluegill, and catfish). Second, although largemouth bass were likely to have $\mathrm{MeHg}$ concentrations higher than the human-health criterion, they were caught and released more often than they were harvested. However, the average size largemouth bass (in both reservoirs) and above-average size walleye (in Monroe Lake) that were harvested for potential human consumption were likely to have $\mathrm{MeHg}$ concentrations higher than the human-health criterion.

\section{Introduction}

Mercury $(\mathrm{Hg})^{1}$ is an environmental contaminant that can pose adverse health risks to humans and wildlife, especially in the form of methylmercury ( $\mathrm{MeHg}$ ), which accumulates and magnifies in aquatic food webs. This data compilation and interpretation of $\mathrm{Hg}$ and $\mathrm{MeHg}$ in selected reservoirs is a case study for Indiana that indicates the potential for similar occurrence in other reservoirs.

\section{Purpose and Scope}

The purpose of this report is to present two sets of U.S. Geological Survey data about Hg and MeHg in water from six flood-control reservoirs in Indiana and to interpret how the $\mathrm{Hg}$ and $\mathrm{MeHg}$ were affected by physical factors and chemical and biological conditions in the reservoirs. (Reservoirs consist of a dam with flow-control structures that include floodgates and bypass valves. Water discharged through the gates or bypass outlets enters a stream channel, where it is termed "tailwater." The water impounded behind the dam is termed "pool.") This report presents $\mathrm{Hg}$ and $\mathrm{MeHg}$ in analyses of water samples from pools and tailwaters of three reservoirs (2009) along with analyses of water samples from tailwaters of four reservoirs (2002-2006). In addition, analyses of fish-tissue samples from eight reservoirs (1996-2007) were compiled from State records and interpreted to depict food-chain accumulation and magnification of MeHg.

The scope of this report is comprehensive. The introduction uses data from Indiana and the scientific literature for an explanation of $\mathrm{Hg}$ and $\mathrm{MeHg}$ in reservoirs, along with reference benchmarks and public health advisories for $\mathrm{Hg}$ in fish. Methods include detailed descriptions of sampling, analysis, measurement, and quality assurance for $\mathrm{Hg}, \mathrm{MeHg}$, and other constituents in water of reservoir pools and tailwaters. Interpretations of the data from Indiana reservoirs are used to

\footnotetext{
${ }^{1}$ In this paper, $\mathrm{Hg}$ is the same as what is sometimes called "total Hg." Total $\mathrm{Hg}$ includes $\mathrm{MeHg}$ by definition, but $\mathrm{MeHg}$ and $\mathrm{Hg}$ concentrations are determined separately.
}

identify the factors and conditions affecting $\mathrm{Hg}$ and $\mathrm{MeHg}$ in water that could apply to reservoirs outside the study. Land cover, landscape, and atmospheric $\mathrm{Hg}$ deposition are examined for their effects on the transport of $\mathrm{Hg}$ to reservoirs. Water chemistry and reservoir characteristics are used to understand conditions that promote formation of $\mathrm{MeHg}$ in the reservoirs. Fish-tissue $\mathrm{Hg}$ data for species caught and harvested from reservoirs are discussed with their implications for human consumption and wildlife.

\section{Mercury and Methylmercury in the Environment}

Aquatic ecosystems receive Hg primarily from atmospheric deposition, originating from $\mathrm{Hg}$ emissions to the atmosphere from human activity (National Research Council, 2000; Lindberg and others, 2007, Driscoll and others, 2013). Wet deposition transfers atmospheric $\mathrm{Hg}$ that is in precipitation (rain, snow, sleet, hail, and fog) to the land surface. Dry deposition transfers gaseous, oxidized, and particulate atmospheric $\mathrm{Hg}$ to vegetation, soil, water, snow, and urban landscapes. Dry deposition occurs continuously and at a slower rate than wet deposition, which is episodic (Zhang and others, 2009). Dry deposition of $\mathrm{Hg}$ can be greater than wet deposition of $\mathrm{Hg}$ in many ecosystems (Lindberg and others, 2007; Zhang and others, 2012).

The Hg in atmospheric deposition is primarily inorganic $\mathrm{Hg}$, which in aquatic ecosystems can be converted to organic $\mathrm{MeHg}$ by microorganisms as a byproduct of their metabolism. Sulfate-reducing bacteria, which process organic matter using sulfate in the environment, take up inorganic $\mathrm{Hg}$ and convert it to $\mathrm{MeHg}$ under certain conditions in riparian wetlands that are hydraulically connected to streams or lakes, as well as in some stream or lake-bottom environments (Morel and others, 1998). This $\mathrm{MeHg}$ can be released into the water by diffusion or resuspension of sediment. Organic carbon can affect the levels and mobility of $\mathrm{Hg}$ and $\mathrm{MeHg}$ in water, thereby enhancing the MeHg availability to the food web (Grigal, 2002; Brigham and others, 2009; Chasar and others, 2009). Methylmercury is highly absorbable and more toxic than inorganic $\mathrm{Hg}$; organisms require a longer time to eliminate $\mathrm{MeHg}$ than $\mathrm{Hg}$, and the amounts of $\mathrm{MeHg}$ in primary producers are preserved in successively higher levels of consumers in individual food chains within the food web (Munthe and others, 2007). Bacteria with $\mathrm{MeHg}$ may be consumed by the next higher level in a food chain, or the bacteria may release the $\mathrm{MeHg}$ to the water, where it can become part of plankton and periphyton (Bell and Scudder, 2007) that are consumed by the next level in a food chain. The concentration of MeHg magnifies in organisms at higher levels in food chains so that the highest concentrations are found in large, old, top-predator and bottom-feeding fish.

Methymercury has been linked to adverse health and reproductive effects in humans and wildlife. The health risks to humans mostly are from fish consumption (Mergler and others, 2007). People and families who catch and eat fish for subsistence have the greatest exposure to MeHg. Methylmercury 
is a potent neurotoxin that can slow nervous-system and cognitive development in young and unborn children. Adults can have adverse neurological and cardiovascular effects from $\mathrm{MeHg}$ exposure. Methylmercury has been linked to congenital birth defects, increased risk of heart attack, renal damage, and blood pressure dysfunction in humans (National Research Council, 2000). Methylmercury can interfere with reproduction in vertebrates (Klaper and others, 2006). Fish-eating mammals and birds exposed to high, environmentally relevant $\mathrm{MeHg}$ levels can have reproductive and developmental impairments and reduced immunity (Scheuhammer and others, 2007). Populationwide effects in terrestrial wildlife have been linked to MeHg (Evers, 2005).

According to Risch and others (2010), the median concentration of $\mathrm{MeHg}$ in Indiana watersheds was 0.10 nanogram per liter $(\mathrm{ng} / \mathrm{L})$, whereas the median concentration of $\mathrm{MeHg}$ in all fish from these watersheds was 0.13 milligram per kilogram $(\mathrm{mg} / \mathrm{kg})$. This comparison demonstrates the complexity of the $\mathrm{Hg}$ cycle in that $\mathrm{MeHg}$ accumulates and concentrates in the aquatic food chain by a factor of at least $1,300,000 .{ }^{2}$ Studies have shown a correlation between atmospheric deposition of $\mathrm{Hg}$ and $\mathrm{MeHg}$ in fish (Cocca, 2001) and between MeHg in water and in fish (Brumbaugh and others, 2001). The strength of these relations has led to a prediction that $\mathrm{Hg}$-emissions reductions will decrease $\mathrm{MeHg}$ concentrations in fish (Harris, Rudd, and others, 2007).

\section{Reference Benchmarks for Mercury and Methylmercury}

In this paper, national criteria are used that can be applied throughout Indiana and other States. Methylmercury (as $\mathrm{Hg}$ ) in fish-tissue samples are compared with $0.30 \mathrm{mg} /$ $\mathrm{kg}$ as the "reference benchmark for human health." The U.S. Environmental Protection Agency (EPA) freshwater waterquality criterion for $\mathrm{MeHg}$ is not based on a concentration in water. Rather, it is based on a concentration for $\mathrm{MeHg}$ in fish tissue that is protective of human health, $0.30 \mathrm{mg} / \mathrm{kg}$ wet weight (hereafter, fish-tissue concentrations refer to wet weight unless otherwise noted) (U.S. Environmental Protection Agency, 2001a). ${ }^{3}$ Guidance for implementing the $\mathrm{MeHg}$ criterion (U.S. Environmental Protection Agency, 2010) states

\footnotetext{
${ }^{2}$ One milligram equals 1,000 micrograms and one microgram equals 1,000 nanograms, which means the $\mathrm{MeHg}$ concentration increase from $0.10 \mathrm{ng} / \mathrm{L}$ in the water to $0.13 \mathrm{mg} / \mathrm{kg}$ in the fish is 1,000 times 1,000 , which equals a $\mathrm{MeHg}$ bioaccumulation factor of $1,300,000$.

${ }^{3} \mathrm{The} 0.30 \mathrm{mg} / \mathrm{kg}$ criterion is based on a total consumption-weighted rate of $0.175 \mathrm{~kg}$ of fish per day (assuming a human adult body weight default value of $70 \mathrm{~kg}$ and a reference dose of $0.001 \mathrm{mg} / \mathrm{kg}$ per day, accounting for different trophic levels of fish.) A reference dose is an estimate (with uncertainty) of a daily oral exposure to the human population (including sensitive subgroups) that is likely to be without an appreciable risk of deleterious effects during a lifetime.
}

the assumption that nearly all of the $\mathrm{Hg}$ in fish-tissue samples is $\mathrm{MeHg},{ }^{4}$ meaning that fish-tissue $\mathrm{Hg}$ concentrations may be compared with the $0.30-\mathrm{mg} / \mathrm{kg} \mathrm{MeHg}$ criterion as if they were $\mathrm{MeHg}$ concentrations. Other reports use this same assumption (for example, U.S. Environmental Protection Agency, 1999, 2009; Harris, Krabbenhoft, and others, 2007; Scudder and others, 2009; Stahl and others, 2009), as do public health advisories for fish consumption (U.S. Environmental Protection Agency, 2010). In this report, $\mathrm{Hg}$ in fish-tissue samples is assumed to be nearly all $\mathrm{MeHg}$ for comparing with the EPA criterion but is called $\mathrm{Hg}$, consistent with the data.

In this report, $\mathrm{Hg}$ in fish-tissue samples are also compared with the "reference benchmark for wildlife," $0.10 \mathrm{mg} /$ $\mathrm{kg}$. The EPA (1997) derived a 0.10-mg/kg fish-tissue MeHg criterion protective of fish-eating mammals, including mink (Mustela vison) and river otter (Lutra canadensis), and a $0.20-\mathrm{mg} / \mathrm{kg}$ fish-tissue $\mathrm{MeHg}$ criterion protective of fish-eating birds, including bald eagle (Haliaeetus leucocephalus), osprey (Pandiaon haliatus), and belted kingfisher (Ceryle alcyon). National assessments of $\mathrm{Hg}$ in lakes (Yeardley and others, 1998) and streams (Scudder and others, 2009) used the more conservative criterion of $0.10 \mathrm{mg} / \mathrm{kg} \mathrm{MeHg}$ for fish-eating mammals and birds to compare with fish-tissue $\mathrm{Hg}$ concentrations. The $0.10-\mathrm{mg} / \mathrm{kg}$ reference benchmark for wildlife also is protective of freshwater fish. In a literature review, Sandheinrich and Wiener (2011) noted that sublethal effects of $\mathrm{Hg}$ on freshwater fish, including changes in reproductive health, were consistently observed in laboratory and field studies for $\mathrm{Hg}$ concentrations exceeding approximately $0.30 \mathrm{mg} / \mathrm{kg}$ in the whole body and $0.50 \mathrm{mg} / \mathrm{kg}$ in the fillet.

Mercury was detected in nearly all fish-tissue samples from national studies of lakes (U.S. Environmental Protection Agency, 2009) and streams (Scudder and others, 2009). The reference benchmark for human health was exceeded in these studies. Results from the statistically based national study of chemical residues in lake fish tissue (U.S. Environmental Protection Agency, 2009) estimated that 49 percent of 76,559 lakes in the lower 48 States had fish with $\mathrm{Hg}$ concentrations that exceeded $0.30 \mathrm{mg} / \mathrm{kg}$. For comparison, a national compilation of fish-tissue $\mathrm{Hg}$ data collected by States for fish consumption advisory programs indicated that approximately 40 percent of the watershed-averaged sample concentrations exceeded $0.30 \mathrm{mg} / \mathrm{kg}$ (U.S. Environmental Protection Agency, 2010).

The reference benchmark for wildlife was exceeded 2 to 3 times more often than the reference benchmark for human health in national studies. Yeardley and others (1998) reported that $\mathrm{Hg}$ concentrations in fish from 26 percent of the lakes in the northeastern United States exceeded $0.30 \mathrm{mg} / \mathrm{kg}$

${ }^{4}$ U.S. Environmental Protection Agency (2010) references four studies in which the mean ratios of $\mathrm{MeHg}$ to $\mathrm{Hg}$ concentrations in fish-tissue samples from studies in the northeastern United States were equal to or higher than 90 percent (Grieb and others, 1990; Bloom, 1992; Becker and Bigham, 1995; and Hammerschmidt and others, 1999). All of the fish species listed for these four studies are found in Indiana. 
and 54 percent exceeded $0.10 \mathrm{mg} / \mathrm{kg}$. For comparison, Scudder and others (2009) reported that Hg in fish from 27 percent (79 of 291) of the stream sample sites in their study exceeded $0.30 \mathrm{mg} / \mathrm{kg}$ and that nearly 75 percent (209 of 291 sites) exceeded $0.10 \mathrm{mg} / \mathrm{kg}$, the reference benchmark for wildlife.

\section{Previous Studies of Mercury in Reservoirs}

Reservoirs, unlike natural lakes, are a part of river systems that are managed for flood control. A condition known as the reservoir effect highlights the importance of $\mathrm{Hg}$ and $\mathrm{MeHg}$ in reservoirs. Methylmercury concentrations in water from new reservoirs increase because decomposition of organic carbon from inundated forest soils and wetlands stimulate microorganisms that form $\mathrm{MeHg}$ from $\mathrm{Hg}$, as documented by numerous investigations summarized in Bodaly and others (2004), Mailman and others (2006), and Stewart and others (2008). The result is that MeHg in the suspended particulate matter and water of reservoirs is higher than in natural lakes. Methylmercury in the water is taken up by phytoplankton and zooplankton, leading to elevated $\mathrm{Hg}$ in fish. Elevated $\mathrm{MeHg}$ may persist for many years after a reservoir is first constructed (Hall and others, 2005; Bodaly and others, 2007), and MeHg in resuspended fine particles transfers to the food chain for a long time in the protected shallow areas of reservoirs (Plourde and others, 1997).

As summarized in Canavan and others (2000), it is known that during seasonal thermal stratification of lakes and reservoirs, conditions develop in the deepest layer of watera layer with relatively low dissolved oxygen - that promote $\mathrm{MeHg}$ formation. Deep reservoirs with long retention times and recurring stratification develop a biochemistry of $\mathrm{MeHg}$ enriched water near the lake bottom. Unlike lakes, reservoirs are designed to release water, which can be enriched with $\mathrm{MeHg}$, depending on the season and the depth of the water that is released from the reservoir.

Reservoir watershed characteristics and water-management actions can increase the potential for $\mathrm{MeHg}$ formation and subsequent bioaccumulation in aquatic organisms. Mast and Krabbenhoft (2010) compared $\mathrm{Hg}$ and $\mathrm{MeHg}$ in water, sediment, zooplankton, and fish from two reservoirs in Colorado. One reservoir had a $\mathrm{Hg}$ fish-consumption advisory and the other did not because in one reservoir, annual water-level fluctuations stimulated $\mathrm{MeHg}$ formation in a more organic-rich sediment of a larger area during reflooding. Negry and others (2011) combined water chemistry, lake, and land-use variables to predict Hg in fish from 17 lakes and reservoirs in California. They found the strongest statistical associations of $\mathrm{Hg}$ in fish were with $\mathrm{Hg}$ in lake sediment, percent forested area, and MeHg in water. Drenner and others (2011) studied factors affecting $\mathrm{Hg}$ in largemouth bass (Micropeterus salmoides) from 145 reservoirs in four ecoregions of Texas. They reported fish with the highest $\mathrm{Hg}$ were from reservoirs in the ecoregion with the highest $\mathrm{Hg}$ and sulfate deposition, extensive forest and wetland land cover, and little agriculture.

\section{Description of the Study Area}

Eight reservoirs (fig. 1) were constructed in Indiana between 1953 and 1979 to prevent downstream flood damage (U.S. Army Corps of Engineers, 2014) - Brookville Lake, Cagles Mill Lake, Cecil M. Harden Lake (C.M. Harden Lake hereafter; also called Raccoon Lake), Mississinewa Lake, Monroe Lake, Patoka Lake, J. Edward Roush Lake (J.E. Roush Lake hereafter; also called Huntington Lake), and Salamonie Lake. Three of these reservoirs in Indiana are sources for a public-water supply-Brookville Lake, Monroe Lake, and Patoka Lake. These riverine reservoirs differ from natural or other constructed lakes because the outflow, internal transport, and retention time are influenced by management for flood control, water supply, and water quality, as well as by inflow from precipitation runoff.

Typical operation of a flood-control reservoir involves impounding water from spring runoff and attaining a summer pool stage that is generally maintained until a drawdown in late summer or early fall. The winter pool stage is established when drawdown is completed, and the reservoir refills until summer pool stage is reestablished. The summer pool areas of the reservoirs in Indiana range from 3.7 to 43.5 square kilometers $\left(\mathrm{km}^{2}\right)$, and upstream drainage areas range from 440 to $2,093 \mathrm{~km}^{2}$ (table 1 ).

\section{Methods}

Data-collection sites for reservoir tailwaters and pools are described in this section. Ultraclean protocols and low-level analyses for measuring $\mathrm{Hg}$ and $\mathrm{MeHg}$ in water are explained. Methods for water sample collection, processing, and analysis are presented, along with quality assurance of $\mathrm{Hg}$ and $\mathrm{MeHg}$ and supplementary constituents. Methods for determination of water-quality characteristics are described, including vertical profiles along reservoir-pool transects.

\section{Data-Collection Sites}

Tailwater sites at four reservoirs-Brookville Lake, Cagles Mill Lake, Mississinewa Lake, and J.E. Roush Lake (fig. 1) - were sampled as part of a statewide network for $\mathrm{Hg}$ in Indiana streams (Ulberg and Risch, 2008). Pools at three reservoirs-Brookville Lake, Monroe Lake, and Patoka Lake (fig. 1) -were investigated because Monroe Lake and Patoka Lake that had not been studied previously and because Brookville Lake was in a different part of Indiana from the other two. Tailwater or pool data were not available for two flood-control reservoirs in Indiana-C.M. Harden Lake and Salamonie Lake.

At the three reservoir pools, vertical profiles of waterquality characteristics were measured at the center of the 5 equal-width increments along 10 to 17 shore-to-shore transects (table 2). The transects were established downstream 
Figure 1. Flood-control reservoirs in Indiana.

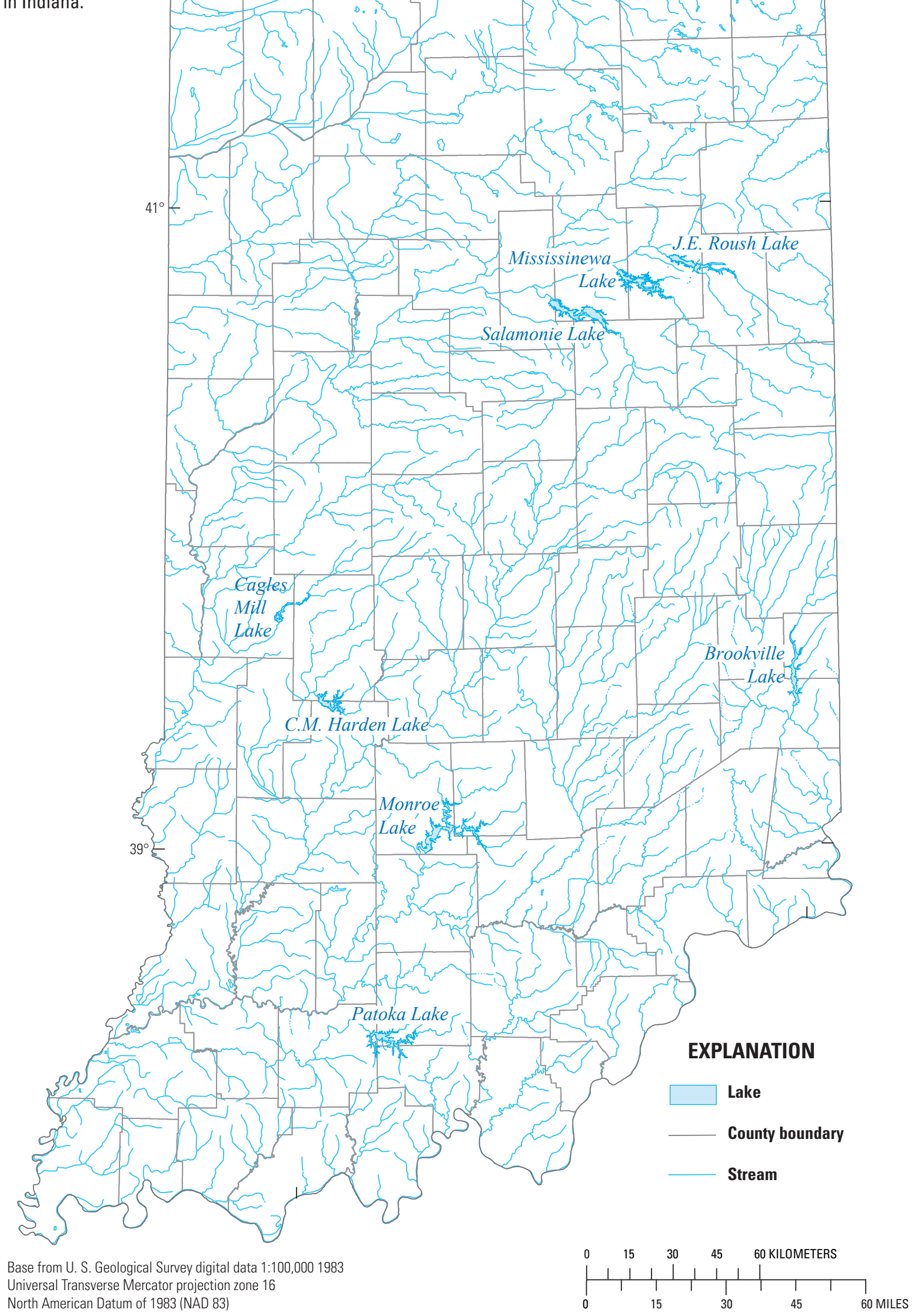


Table 1. Selected information for flood-control reservoirs in Indiana.

[km², square kilometer; km, kilometer; USGS, U.S. Geological Survey; --, no data]

\begin{tabular}{|c|c|c|c|c|c|c|c|c|c|c|c|c|}
\hline $\begin{array}{c}\text { Reservoir project } \\
\text { name }\end{array}$ & $\begin{array}{c}\text { Summer } \\
\text { pool } \\
\text { area } \\
\left(\mathbf{k m}^{2}\right)\end{array}$ & $\begin{array}{c}\text { Summer } \\
\text { pool } \\
\text { length } \\
\text { (km) }\end{array}$ & $\begin{array}{c}\text { Winter } \\
\text { pool } \\
\text { area } \\
\left(\mathbf{k m}^{2}\right)\end{array}$ & $\begin{array}{l}\text { Winter } \\
\text { pool } \\
\text { length } \\
\text { (km) }\end{array}$ & $\begin{array}{l}\text { Drainage } \\
\text { area }\left(\mathrm{km}^{2}\right)\end{array}$ & $\begin{array}{l}\text { Average } \\
\text { annual } \\
\text { retention } \\
\text { time }{ }^{1} \text { (days) }\end{array}$ & $\begin{array}{c}\text { Difference } \\
\text { of summer } \\
\text { and winter } \\
\text { pool }\left(\mathbf{k m}^{2}\right)\end{array}$ & $\begin{array}{c}\text { Difference } \\
\text { as percent } \\
\text { of summer } \\
\text { pool }\end{array}$ & $\begin{array}{c}\text { USGS } \\
\text { gaging-station } \\
\text { number }^{2}\end{array}$ & $\begin{array}{c}\text { Name } \\
\text { of impounded stream }\end{array}$ & $\begin{array}{c}\text { Year } \\
\text { of full } \\
\text { pool }\end{array}$ & $\begin{array}{l}\text { Water } \\
\text { supply }\end{array}$ \\
\hline Brookville Lake & 21.3 & 26.4 & 18.3 & 24.1 & 984 & 202 & 3.0 & 14 & 03276000 & East Fork Whitewater River & 1974 & Yes \\
\hline Cagles Mill Lake & 5.9 & 16.1 & 5.7 & 16.1 & 761 & 44 & 0.3 & 4 & 03359000 & Mill Creek & 1953 & No \\
\hline C.M. Harden Lake ${ }^{3}$ & 8.5 & 17.4 & 4.5 & 10.8 & 562 & 128 & 4.1 & 48 & 03340900 & Big Raccoon Creek & 1961 & No \\
\hline Mississinewa Lake & 12.9 & -- & 5.2 & -- & 2,093 & 41 & 7.7 & 60 & 03327000 & Mississinewa River & 1968 & No \\
\hline Monroe Lake & 43.5 & 59.5 & 43.5 & 59.5 & 1,119 & 199 & 0.0 & 0 & 03372500 & Salt Creek & 1966 & Yes \\
\hline Patoka Lake & 35.4 & 40.2 & 33.1 & 37.8 & 440 & 556 & 2.3 & 6 & 03374500 & Patoka River & 1979 & Yes \\
\hline J.E. Roush Lake ${ }^{4}$ & 3.7 & 11.3 & 2.3 & 8.0 & 1,867 & 10 & 1.4 & 37 & 03323500 & Wabash River & 1969 & No \\
\hline Salamonie Lake & 9.2 & 27.4 & 3.5 & 17.7 & 1,443 & 51 & 5.7 & 62 & 03324500 & Salamonie River & 1974 & No \\
\hline
\end{tabular}

${ }^{1}$ Average annual retention time, 1984-2007 (U.S. Army Corps of Engineers, written commun., 2009); all other data from U.S. Army Corps of Engineers (2014)

${ }^{2}$ Nearest gaging station downstream from reservoir.

${ }^{3}$ Also called Raccoon Lake.

${ }^{4}$ Also called Huntington Lake. 
from the confluence of contributing streams, downstream from major bays and inlets, near dams, and in places where they would bracket water-quality sample locations. Transects were identified on maps and aerial photographs, and a geographic information system (GIS) was used to determine the coordinates of transect endpoints and the centers of five equal-width increments. A global positioning system (GPS) and digital map interface on the watercraft were used to navigate to the transects and increment center points. A total of 1,440 depthspecific measurements of water-quality characteristics were measured at 1.52-meter (m) (5-foot [ft]) intervals from the water surface to the lake bottom along each transect (fig. 2), creating a vertical profile.
The sampling design for the three reservoirs included sites in headwaters, inlets, main body, area near the dam, and tailwater. A depth-sounding fathometer connected to the GPS and digital map interface on the watercraft were used to record bathymetric data of the lake-bottom topography along each transect (fig 2). The fathometer was used to identify the thalweg of the original stream channel as the deepest water with all three thermal strata present. At sampling sites between transects in the main body of the lake, a vertical profile of water-quality characteristics was measured to selected depths for two or three point samples. Sites in the headwaters and inlets or bays typically involved water depths less than $2 \mathrm{~m}$ and included a point sample at a single depth.

Table 2. Reservoir-pool water-quality transect information.

\begin{tabular}{lccccc}
\hline Reservoir & $\begin{array}{c}\text { Number of } \\
\text { transects }\end{array}$ & $\begin{array}{c}\text { Mean } \\
\text { transect } \\
\text { length } \\
\text { (meters) }\end{array}$ & $\begin{array}{c}\text { Range of } \\
\text { transect } \\
\text { lengths } \\
\text { (meters) }\end{array}$ & $\begin{array}{c}\text { Maximum } \\
\text { water depth } \\
\text { (meters) }\end{array}$ & $\begin{array}{c}\text { Number of } \\
\text { measurements }\end{array}$ \\
\hline Brookville Lake & 10 & 235 & $83-408$ & 32.3 & 523 \\
Monroe Lake & 14 & 272 & $131-525$ & 13.7 & 333 \\
Patoka Lake & 17 & 166 & $73-413$ & 12.8 & 584 \\
\hline
\end{tabular}

${ }^{1}$ At each measurement, a total of five water-quality characteristics were determined. Measurements were made at 1.52-meter (5-foot) intervals from the water surface to lake bottom.

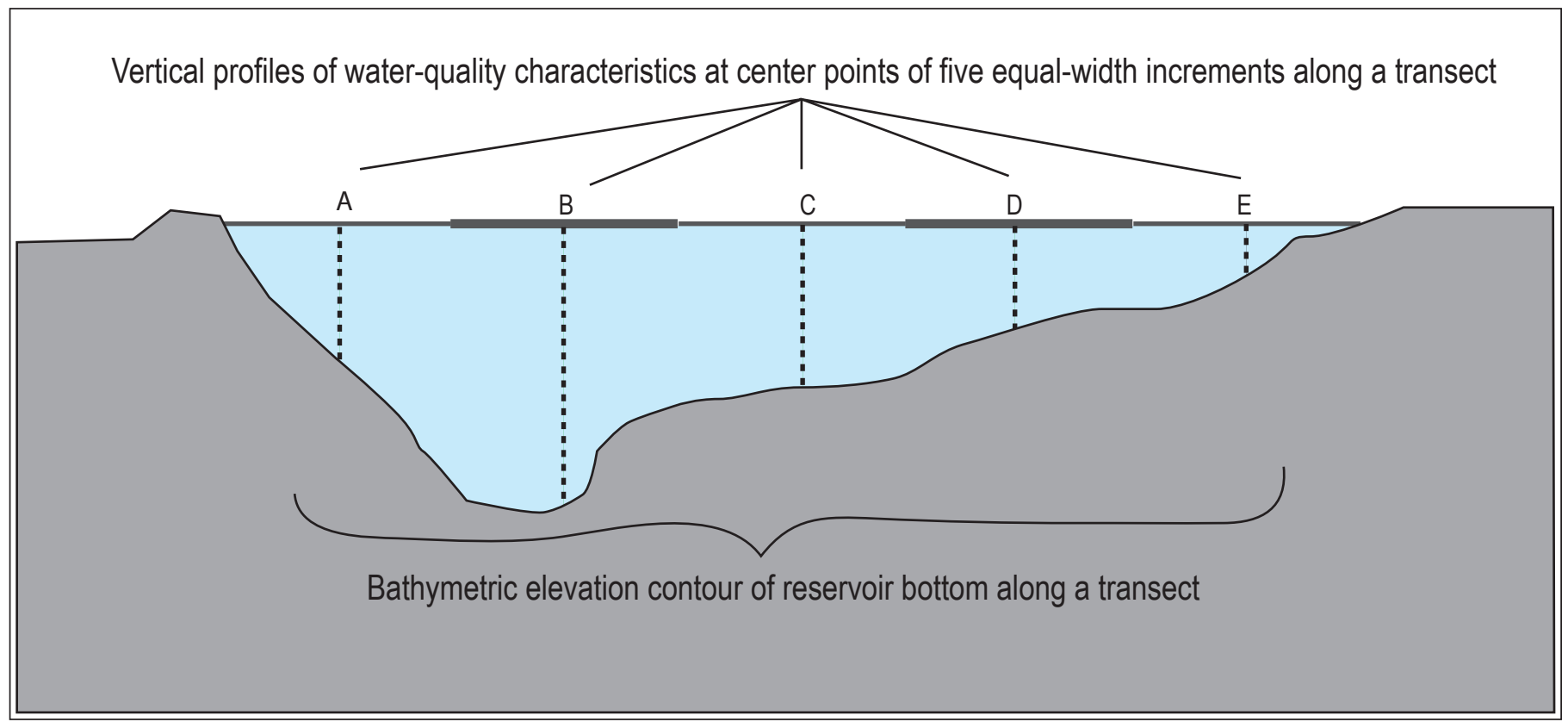

Figure 2. Generalized diagram of reservoir-pool-monitoring transect, water-quality verticals, and lake-bottom topography. 


\section{Water-Quality Characteristics}

Five water-quality characteristics were measured at the tailwater and reservoir-pool sites and in the vertical profiles along the 10 to 17 transects in each reservoir pool. A multiparameter instrument was used to measure $\mathrm{pH}$, specific conductance, dissolved oxygen, and water temperature (table 3). The meter was calibrated each day prior to its use, following procedures outlined in U.S. Geological Survey (variously dated). A portable optical turbidimeter was used to measure turbidity in three aliquots of each water sample, and the median was reported. The turbidimeter was checked with secondary standards each day prior to its use. The water sample for turbidity at the tailwater sites came from a composite sample mixed in a churn-style sample splitter. The water sample for turbidity at the reservoir sites was a depth-specific grab sample collected with a Kemmerer sampler. Water-quality characteristics were determined at the time of water-sample collection at the tailwater sites as described in Ulberg and Risch (2008). For the 2002-2006 and 2009 tailwater sites, the values of the water-quality characteristics were a composite integrated through the stream width and depth. For the 2009 reservoirpool sites, depth-specific point measurements of water-quality characteristics were made at the depth the water samples were collected.

\section{Water-Sample Collection, Processing, and Analysis}

Ultraclean protocols were used for collecting water samples to be analyzed for $\mathrm{Hg}$ and $\mathrm{MeHg}$, described in U.S. Geological Survey (variously dated). These protocols are designed to avoid the unintentional introduction of $\mathrm{Hg}$ or other contaminants into a sample and are comparable to trace-metals methods in EPA Method 1669 (U.S. Environmental Protection Agency, 1996) and the USGS Inorganic Protocol (Horowitz and others, 1994). Supplies that contacted water samples (sample bottles, pump tubing, and filter holders) were made of fluorocarbon resin (Teflon), specially cleaned in the laboratory with hot acid and $\mathrm{Hg}$-free water rinses, dried, and double bagged. Supplies were used for one sample and returned to the laboratory for cleaning. Equipment that contacted water samples (intake weight, sampler cap and nozzle, and churn) also were made of fluorocarbon resin. These equipment items were cleaned with a series of detergent, $\mathrm{Hg}$-free water, and acid rinses between samples. Personnel wore powder-free disposable nitrile gloves that were changed frequently to protect sample integrity. A minimum of two USGS personnel collected samples; one person handled sample bottles and inner bags of double-bagged supplies, and the other person handled sampling equipment and the outer bag of double-bagged supplies.

Water samples at three reservoir pools were collected from a motorized watercraft with the motor off and the watercraft anchored fore and aft. Depth-specific point samples were collected with a peristaltic-pump apparatus (fig. 3) suspended from a handline. A Teflon weight with intake ports was lowered with a Kevlar handline to the desired sampling depths. The weight was connected to an optimal length of small-diameter Teflon tubing inserted in a short piece of flex tubing at the pump head. Water was pumped into sample bottles handled inside an isolation chamber on the watercraft.

Water samples were collected at tailwater sites by using stream-width- and streamflow-integrating techniques described in Ulberg and Risch (2008) and Risch and others (2010). Water samples were collected from a bridge, while wading, or from an inflatable, rubberized boat with a wooden floor (at Cagles Mill Lake). Samples were collected from a bridge by use of an isokinetic sampler suspended from a cable reel on a portable bridge crane. Samples were collected while wading or from a boat by use of an isokinetic sampler on a rod. Representative samples were collected according to USGS procedures that are intended to composite water collected across the full width and depth of the stream, thus accounting for differences in velocity and water chemistry.

Water samples collected for $\mathrm{Hg}$ and $\mathrm{MeHg}$ analysis were transported or shipped overnight to the USGS Indianapolis office, where they were processed within 24 hours of collection. Water samples for $\mathrm{Hg}$ and $\mathrm{MeHg}$ analysis were filtered and preserved in a Class 100, laminar-flow, high-efficiency particulate-air-filter workstation. Filtered water and particulate samples were prepared by vacuum filtration, using equipment and procedures described in U.S. Geological Survey (variously dated). Water samples for $\mathrm{Hg}$ and $\mathrm{MeHg}$ analysis were preserved with concentrated high-purity hydrochloric acid. Particulate sample filters were frozen until analysis for $\mathrm{Hg}$ and MeHg.

Table 3. Methods and reporting limits for determinations of water-quality characteristics.

$\left[\mu \mathrm{S} / \mathrm{cm}\right.$, microsiemens per centimeter; $\mathrm{mg} / \mathrm{L}$, milligram per liter; ${ }^{\circ} \mathrm{C}$, degree Celsius; NTRU, nephelometric turbidity ratio unit $]$

\begin{tabular}{llc}
\hline \multicolumn{1}{c}{ Constituent or property } & \multicolumn{1}{c}{ Method } & Reporting limit, precision, and unit \\
\hline $\mathrm{pH}$ & In situ measurement with multiparameter instrument & $0.1 \pm 0.01 \mathrm{standard} \mathrm{unit}$ \\
Specific conductance & In situ measurement with multiparameter instrument & $1 \pm 1 \mu \mathrm{S} / \mathrm{cm}$ \\
Dissolved oxygen & In situ measurement with multiparameter instrument & $0.01 \pm 0.01 \mathrm{mg} / \mathrm{L}$ \\
Water temperature & In situ measurement with multiparameter instrument & $0.01 \pm 0.01^{\circ} \mathrm{C}$ \\
Turbidity & Field measurement of composite sample with portable turbidimeter & $0.1 \pm 0.1 \mathrm{NTRU}$ \\
\hline
\end{tabular}




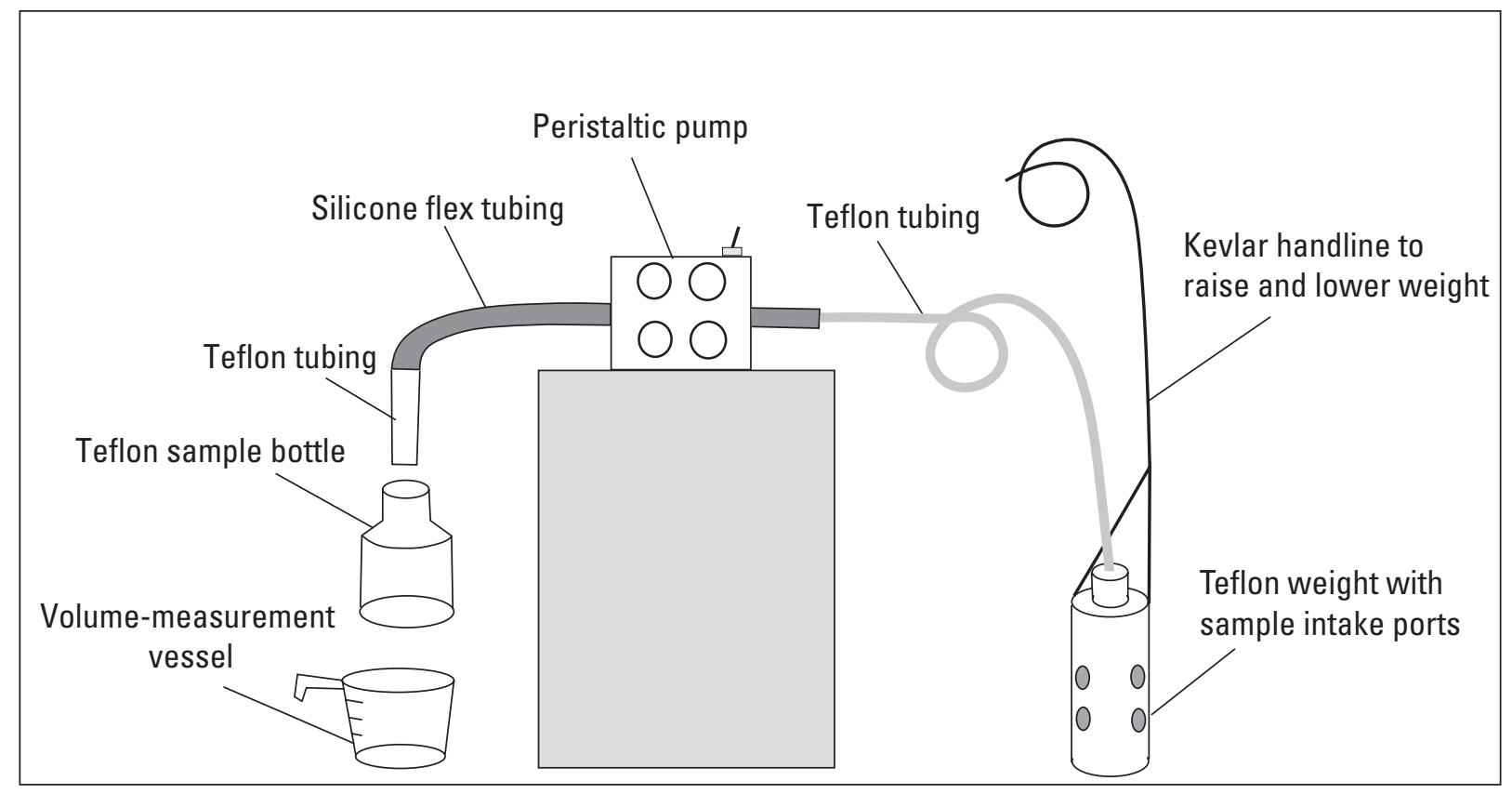

Figure 3. Apparatus for collection of water samples for mercury analysis.

Water and particulate samples collected by USGS were analyzed for low-level $\mathrm{Hg}^{5}$ and $\mathrm{MeHg}$ (table 4) at the USGS Mercury Research Laboratory. Mercury concentration was determined by oxidation, purge and trap, and cold vapor atomic fluorescence spectrometry (Olson and DeWild, 1997), equivalent to EPA Method 1631 (U.S. Environmental Protection Agency, 2002). Methylmercury samples were prepared by distillation and analyzed by aqueous phase ethylation and gas chromatography separation with cold vapor atomic fluorescence detection (DeWild and others, 2002), equivalent to EPA Method 1630 (U.S. Environmental Protection Agency, 2001c).

Analytical data for the tailwater samples included determinations of $\mathrm{Hg}$ and $\mathrm{MeHg}$ in unfiltered and filtered forms, in which case "particulate" $\mathrm{Hg}$ and $\mathrm{MeHg}$ concentrations were computed as the difference of unfiltered and filtered forms. Analytical data for the reservoir pool and tailwater samples included determinations of $\mathrm{Hg}$ and $\mathrm{MeHg}$ in particulate forms measured on filters and dissolved forms in filtered water. In this case, "whole-water" $\mathrm{Hg}$ and $\mathrm{MeHg}$ concentrations were computed as the sum of dissolved and particulate forms. ${ }^{6}$ If a dissolved or particulate concentration was less than the reporting limit for a sample, it was assumed to be zero for computing a whole-water concentration, consistent with the approach

\footnotetext{
${ }^{5}$ In this report, the analytical determination of $\mathrm{Hg}$ means total $\mathrm{Hg}$.

${ }^{6}$ In water samples with levels of suspended particulates consistent with turbidity values higher than 20 nephelometric ratio turbidity units (NTRU), the $\mathrm{MeHg}$ concentration in an unfiltered sample is generally equivalent to the sum of dissolved and particulate $\mathrm{MeHg}$ concentrations, if reporting limits are the same. Unfiltered water samples with less than 20 NTRU and low levels of suspended particulates generally will have lower $\mathrm{MeHg}$ concentrations than those determined as the sum of dissolved and particulate $\mathrm{MeHg}$ concentrations. This difference is attributable to the more sensitive particulate $\mathrm{MeHg}$ determination.
}

used by other investigators (for example, Brigham and others, 2009). The "ratio of the $\mathrm{MeHg}$ to $\mathrm{Hg}$ concentration" in this report can refer to the ratios of unfiltered $\mathrm{MeHg}$ to unfiltered $\mathrm{Hg}$, whole-water $\mathrm{MeHg}$ to whole-water $\mathrm{Hg}$, or dissolved $\mathrm{MeHg}$ to dissolved $\mathrm{Hg}$, depending on context.

Reservoir-pool water samples for analysis of dissolved sulfate, organic carbon, particulate carbon and nitrogen, and chlorophyll were filtered and processed in a mobile laboratory van within a few hours of sample collection, following procedures in U.S Geological Survey (variously dated) and references in table 4 .

\section{Quality Assurance}

Quality assurance included analysis of field and laboratory quality-control samples, and the USGS laboratory followed a written quality-assurance plan (U.S. Geological Survey, 2007). Field quality-control data for tailwater samples were explained and evaluated by Ulberg and Risch (2008). These quality-control data indicated that the $\mathrm{Hg}$ and $\mathrm{MeHg}$ data from tailwater samples were representative and unbiased.

For the reservoir-pool water samples, field blank samples (source water/bottle blanks and equipment blanks) were prepared to evaluate cleaning of the sampling equipment. Field blank data were evaluated by using procedures for EPA Method 1631 (U.S. Environmental Protection Agency, 2001b). Field duplicate samples were collected by sequentially filling a second set of sample bottles from the same tubing. Field duplicate samples were a measure of the natural variability of $\mathrm{Hg}$ concentrations in the water and the variability associated with sample collection and processing, rather than a measure of analytical precision. Analytical precision in the determination 
Table 4. Methods for analysis of mercury, particulate, and supplementary constituents in water.

$\left[\mathrm{ng} / \mathrm{L}\right.$, nanogram per liter; $\mu \mathrm{m}$, micrometer (pore size of filters); $\mathrm{HCl}$, hydrochloric; $\mathrm{mg} / \mathrm{L}$, milligram per liter; ${ }^{\circ} \mathrm{C}$, degree Celsius $]$

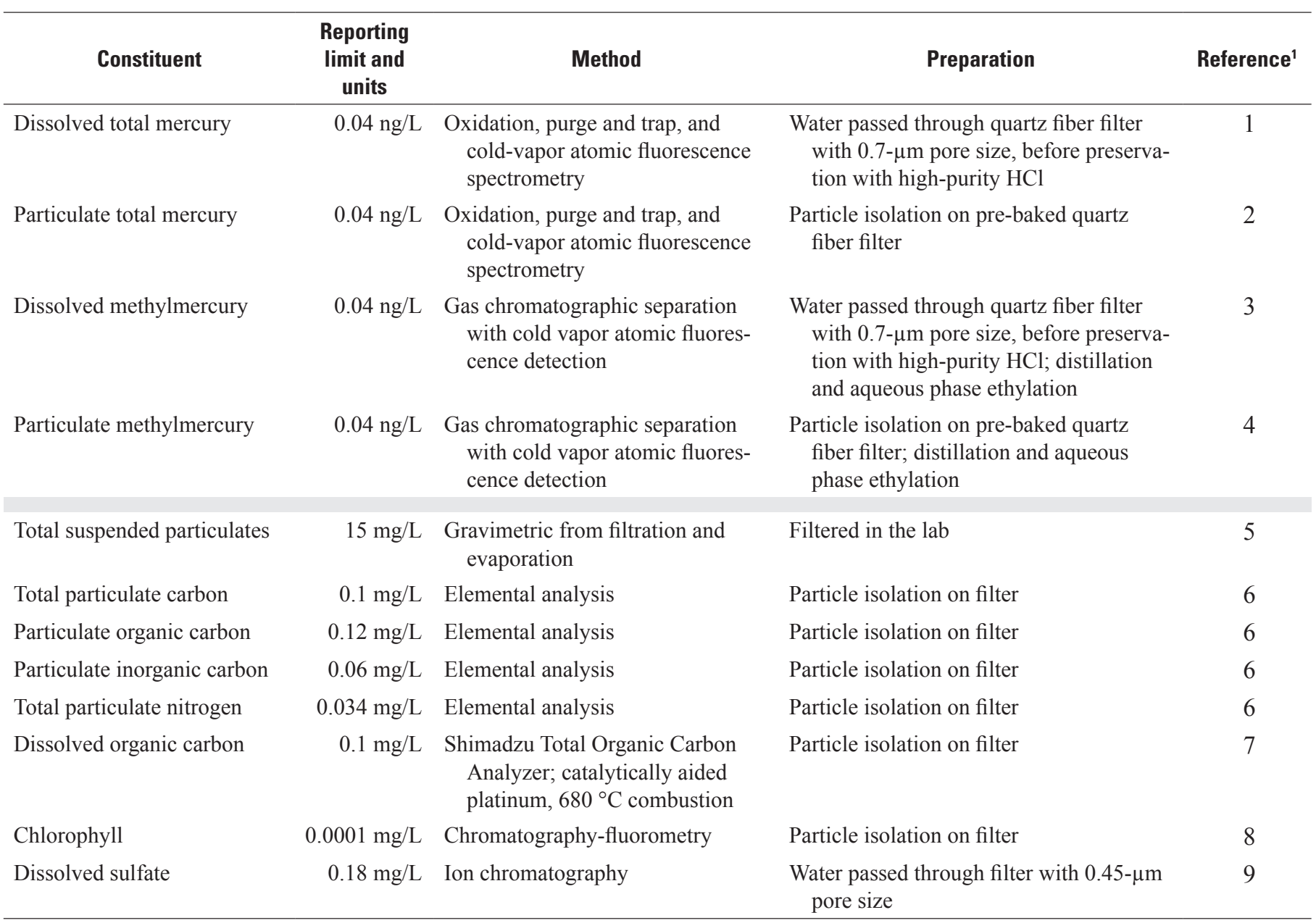

\footnotetext{
${ }^{1}$ References:

1. Olson and DeWild, 1997.

2. Olson and DeWild, 1997; Olund and others, 2004.

3. DeWild and others, 2002.

4. DeWild and others, 2002; DeWild and others, 2004.

5. Guy, 1969.

6. Patton and others, 2000.

7. Based on Bird and others, 2003.

8. Arar and Collins, 1997.

9. Fishman and Friedman, 1989.
}

of $\mathrm{Hg}$ concentrations was quality assured by the laboratory through analysis of duplicate or triplicate aliquots of water from the same sample bottle until a control limit for relative percent difference of less than 10 percent was attained.

Field quality-control data indicated the analytical results for water samples from the three reservoirs were representative and comparable. Field blank samples for the pool and tailwater samples indicated no bias caused by $\mathrm{Hg}$ or $\mathrm{MeHg}$ artifacts from sampling (appendix table 1-1). Precision of $\mathrm{Hg}$ and $\mathrm{MeHg}$, affected by natural variability and variability from sampling and processing, was measured by relative percent difference $^{7}$ (RPD) in pairs of field duplicate samples. Particulate $\mathrm{Hg}$ and dissolved $\mathrm{Hg}$ were reported in all duplicates, and the mean RPD was less than 20 percent (appendix table 1-2). Particulate and dissolved $\mathrm{MeHg}$ were reported in six duplicates, and the mean RPD was less than 25 percent.

\footnotetext{
${ }^{7}$ Relative percent difference is the nonnegative difference of the paired duplicate sample concentrations divided by the average of the concentrations, expressed as a percentage.
} 


\section{Mercury and Methylmercury in Reservoirs in Indiana}

The available data for $\mathrm{Hg}$ and $\mathrm{MeHg}$ in reservoir tailwaters and reservoir pools in Indiana are presented here. Principal topics discussed are (1) factors related to the transport of $\mathrm{Hg}$ to reservoirs, (2) factors related to the conversion of $\mathrm{Hg}$ to $\mathrm{MeHg}$ in reservoirs, and (3) fish-tissue $\mathrm{Hg}$ data, which are presented and used to depict the food-web accumulation and magnification of $\mathrm{MeHg}$.

\section{Reservoir Tailwaters}

Mercury and $\mathrm{MeHg}$ data from analysis of 66 water samples collected at 4 reservoir tailwater sites in IndianaBrookville Lake, Cagles Mill Lake, J.E. Roush Lake, and Mississinewa Lake - are summarized in table 5 and listed in appendix table $1-3$. Unfiltered $\mathrm{Hg}$ concentrations in the tailwater samples ranged up to $15.0 \mathrm{ng} / \mathrm{L}$, and the mean was $2.6 \mathrm{ng} / \mathrm{L}$ (figs. $4 A-4 D$ ) . The ratio of particulate $\mathrm{Hg}$ to $\mathrm{Hg}$ was a maximum of 100 percent, and the mean was 58.4 percent. The ratio of unfiltered $\mathrm{MeHg}$ to $\mathrm{Hg}$ was a maximum of 64.8 percent (fig. $4 E$ ), and the mean was 9.1 percent. By comparison, in samples from sites on free-flowing streams, the mean ratio of particulate $\mathrm{Hg}$ to $\mathrm{Hg}$ was higher (67 percent) and the mean ratio of unfiltered $\mathrm{MeHg}$ to $\mathrm{Hg}$ was lower (3.6 percent) (Risch and others, 2010).
Statistical analysis ${ }^{8}$ indicated significant seasonal differences in $\mathrm{Hg}$ and $\mathrm{MeHg}$ concentrations (Kruskal-Wallis, $\mathrm{p}=0.035, \mathrm{p}=0.017$ ) and in the ratio of unfiltered $\mathrm{MeHg}$ to $\mathrm{Hg}$ $(\mathrm{p}=0.008)$. Unfiltered $\mathrm{Hg}$ concentrations in winter samples (median, $2.7 \mathrm{ng} / \mathrm{L}$ ) were higher than those in autumn samples (median, $1.2 \mathrm{ng} / \mathrm{L}$ ). Unfiltered MeHg concentrations in summer samples (median, $0.13 \mathrm{ng} / \mathrm{L}$ ) were significantly higher than those in autumn samples (median, $<0.04 \mathrm{ng} / \mathrm{L}$ ). The ratios of unfiltered $\mathrm{MeHg}$ to $\mathrm{Hg}$ from summer samples (median, 10.9 percent) were significantly higher than those in winter samples (median, 1.7 percent). The ratios of unfiltered $\mathrm{MeHg}$ to Hg for Cagles Mill Lake, J.E. Roush Lake, and Mississinewa Lake were nearly always highest in summer (appendix table 1-3, fig. 4).

\footnotetext{
${ }^{8}$ Nonparametric statistical methods were used to compare data from different sites and seasons and to evaluate the strength and significance of relations among variables. According to Helsel and Hirsch (1995), nonparametric tests minimize the effect of outliers and apply to sample sizes of 15 to 19 . A significance level of $\alpha=0.05$ was used for the statistical tests, and a p-value less than 0.05 indicated a significant difference. The Kruskal-Wallis rank-sum test (called Kruskal-Wallis hereafter) was used to evaluate whether the distributions of data from more than two groups were different. The Tukey multiple comparison of medians of 95-percent confidence intervals (called Tukey hereafter) was used to determine which groups were significantly different, regardless of the group size. Strengths and significance of statistical correlations were evaluated with the Spearman rank correlation coefficient (rho), where near zero is weak and near 1 is strong correlation. Hereafter, rho means Spearman's rho.
}

Table 5. Mercury data summary for tailwaters at four reservoirs in Indiana.

[Hg, unfiltered mercury; ng/L, nanogram per liter; $\mathrm{PHg}$, particulate mercury; $\mathrm{MeHg}$, unfiltered methylmercury]

\begin{tabular}{|c|c|c|c|c|}
\hline Reservoir & $\begin{array}{l}\text { Summary } \\
\text { description }\end{array}$ & $\begin{array}{c}\mathrm{Hg} \\
\text { (ng/L) }\end{array}$ & $\begin{array}{l}\text { Ratio of } \mathrm{PHg} \text { to } \mathrm{Hg} \\
\text { (percent) }^{1}\end{array}$ & $\begin{array}{c}\text { Ratio of MeHg to } \\
\mathrm{Hg} \text { (percent) }\end{array}$ \\
\hline \multirow{3}{*}{$\begin{array}{l}\text { All four reservoirs } \\
\text { (66 samples) }\end{array}$} & Maximum & 15 & 100 & 64.8 \\
\hline & Mean & 2.6 & 58.4 & 9.1 \\
\hline & Detections $^{3}$ & 65 & 64 & 34 \\
\hline \multirow{3}{*}{$\begin{array}{l}\text { Brookville Lake } \\
\text { (17 samples) }\end{array}$} & Maximum & 1.8 & 100 & 15.4 \\
\hline & Mean & 0.6 & 47.3 & 15.4 \\
\hline & Detections $^{3}$ & 17 & 16 & 1 \\
\hline \multirow{3}{*}{$\begin{array}{l}\text { Cagles Mill Lake } \\
\text { (18 samples) }\end{array}$} & Maximum & 3.3 & 100 & 64.8 \\
\hline & Mean & 1.8 & 60.1 & 20.6 \\
\hline & Detections $^{3}$ & 18 & 18 & 8 \\
\hline \multirow{3}{*}{$\begin{array}{l}\text { J.E. Roush Lake } \\
\text { (16 samples) }\end{array}$} & Maximum & 15.0 & 87 & 15 \\
\hline & Mean & 5.0 & 65.5 & 5.2 \\
\hline & Detections $^{3}$ & 16 & 15 & 14 \\
\hline \multirow{3}{*}{$\begin{array}{l}\text { Mississinewa Lake } \\
\text { (15 samples) }\end{array}$} & Maximum & 6.6 & 100 & 16 \\
\hline & Mean & 2.9 & 61.3 & 5.1 \\
\hline & Detections $^{3}$ & 15 & 15 & 11 \\
\hline
\end{tabular}

${ }^{1}$ Ratio of particulate $\mathrm{Hg}$ to unfiltered $\mathrm{Hg}$, multiplied by 100

${ }^{2}$ Ratio of unfiltered $\mathrm{MeHg}$ to unfiltered $\mathrm{Hg}$, multiplied by 100.

${ }^{3}$ Reporting limits for $\mathrm{Hg}$ and $\mathrm{MeHg}$ were $0.3 \mathrm{ng} / \mathrm{L}$ in 2002-2003 and $0.04 \mathrm{ng} / \mathrm{L}$ in 2004-2006. 

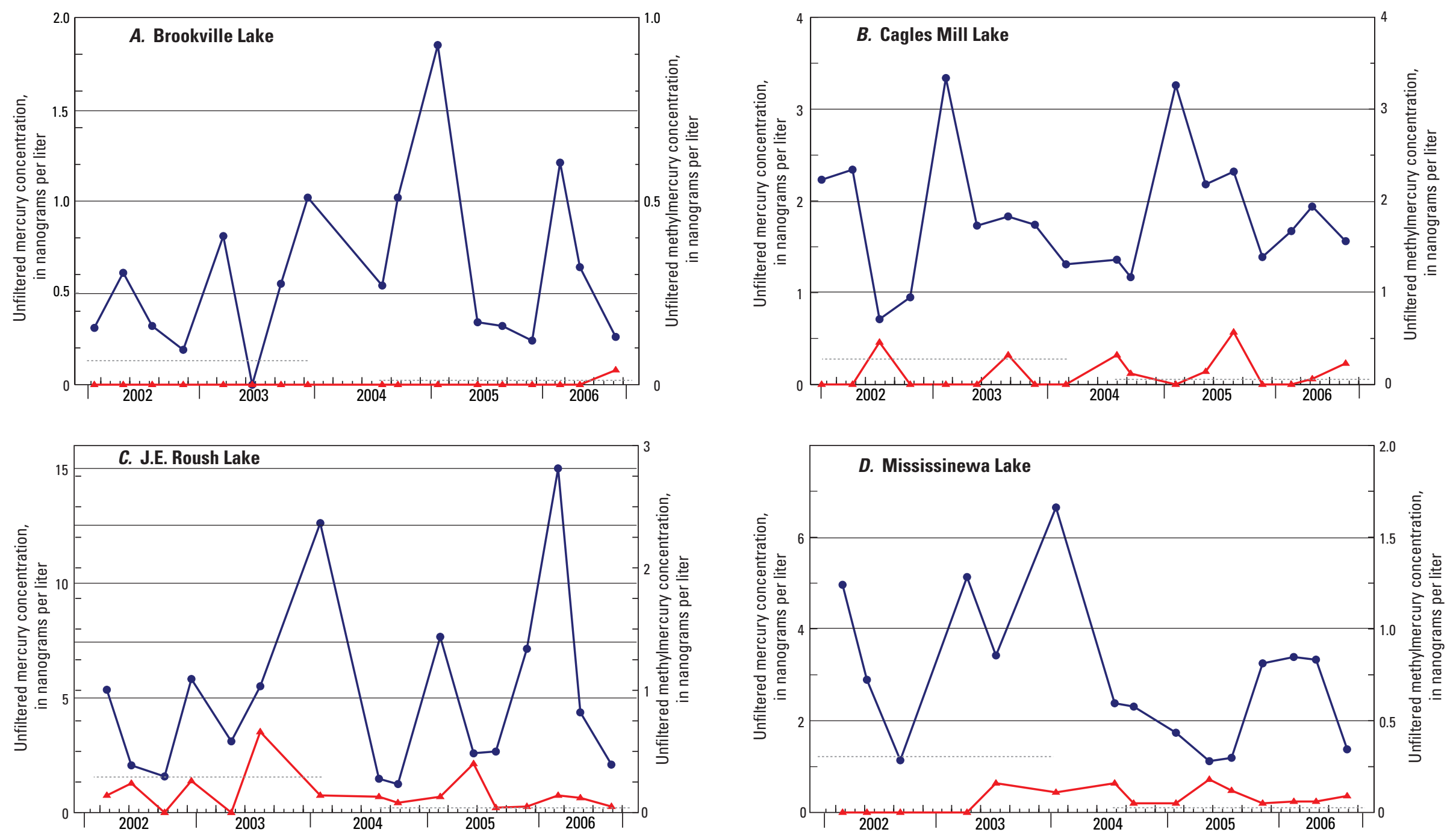

\section{EXPLANATION}

[Note differences in vertical scales]

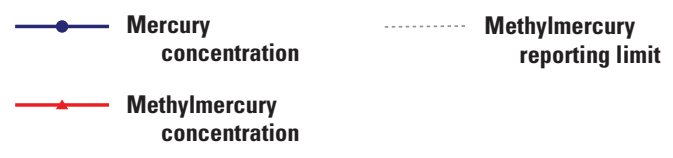

Figure 4. Mercury and methylmercury concentrations in water samples from tailwater sites at four reservoirs. 
E. Ratio of unfiltered methylmercury to unfiltered mercury in four reservoirs
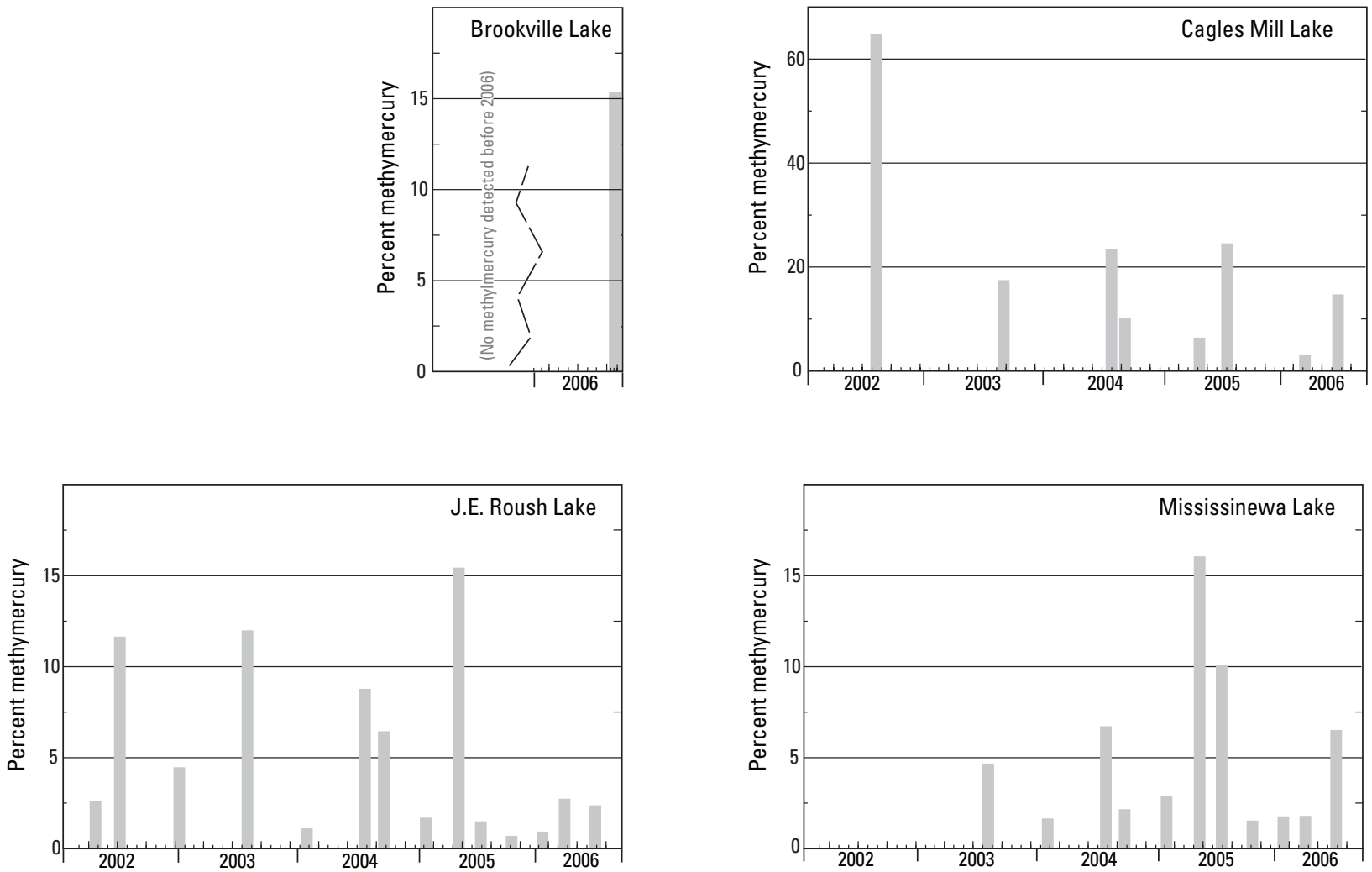

\section{EXPLANATION}

[Note differences in vertical scales]

Percent methylmercury

Figure 4. Mercury and methylmercury concentrations in water samples from tailwater sites at four reservoirs.-Continued 
Concentrations of unfiltered $\mathrm{Hg}$ and $\mathrm{MeHg}$ from Brookville Lake tailwater samples (appendix tables 1-3) were determined to be significantly lower than concentrations in tailwater samples from the other three reservoirs (KruskalWallis, $\mathrm{p}<0.001$; Tukey). The median whole-water Hg concentration from Brookville Lake tailwater samples was $0.54 \mathrm{ng} / \mathrm{L}$ (table 5), compared with medians in the tailwater samples from Cagles Mill Lake (1.7 ng/L), J.E. Roush Lake (3.7 ng/L), and Mississinewa Lake (2.9 ng/L). Whole-water $\mathrm{MeHg}$ was detected in only 1 of 17 tailwater samples from Brookville Lake (0.04 ng/L).

The summer pool area of Mississinewa Lake was 60 percent larger than the winter pool area, and the summer pool area of J.E. Roush Lake was 37 percent larger than the winter pool (table 1). For these two reservoirs, $\mathrm{MeHg}$ was reported in most of the tailwater samples-73 percent for Mississinewa Lake and 93 percent for J.E. Roush Lake. Other studies have shown that reservoirs with fluctuating water levels create periodic reduction and oxidation conditions, which in turn create and release $\mathrm{MeHg}$ into the water (Kelly and others, 1997; St. Louis and others, 2004; Mast and Krabbenhoft, 2010).

\section{Reservoir Pools}

One round of 53 water samples was collected at the reservoir pools-16 samples from 8 sites at Brookville Lake, 17 samples from 9 sites at Monroe Lake, and 20 samples from 12 sites at Patoka Lake. Maps showing locations of the sampling sites are in figures 5, 6, and 7, and information about the sampling sites is in table 6. Precipitation runoff was minimal during a 5-day time period when sampling took place at each reservoir, making the sets of data from each reservoir internally representative of similar hydrologic conditions (appendix table 1-4).

Whole-water $\mathrm{Hg}$ (the sum of particulate and dissolved $\mathrm{Hg}$ fractions) was detected in all 53 water samples from the pools and tailwaters of the three reservoirs (appendix table 1-5). Median and maximum whole-water $\mathrm{Hg}$ concentrations in samples from the pools of Monroe Lake and Patoka Lake were considerably higher than those from Brookville Lake (table 7). The whole-water $\mathrm{Hg}$ concentration in the tailwater sample from Monroe Lake was higher than the median concentration from the Monroe Lake pool samples, unlike Brookville Lake and Patoka Lake, where the tailwater concentration was lower. At Brookville Lake, whole-water Hg concentrations were less than $2 \mathrm{ng} / \mathrm{L}$ in all samples (fig. 8). At Monroe Lake, wholewater $\mathrm{Hg}$ concentrations were higher than $2 \mathrm{ng} / \mathrm{L}$ in samples collected below $8-\mathrm{m}$ depths in the main body of the lake and at headwater sites (fig. 9). At Patoka Lake, the highest wholewater $\mathrm{Hg}$ concentrations were in samples collected below 9-m depths in the main body of the lake and at headwater sites (fig. 10). Whole-water $\mathrm{Hg}$ concentrations in the pool of Brookville Lake did not have a pattern with depth like those from Monroe Lake and Patoka Lake. Reservoir-pool data (table 7) also indicated lower median Hg in Brookville Lake $(0.56 \mathrm{ng} / \mathrm{L})$, compared with medians in the pool samples from Monroe Lake (1.36 ng/L) and Patoka Lake (1.24 ng/L). Methylmercury was detected in 1 of 16 samples from Brookville Lake $(0.13 \mathrm{ng} / \mathrm{L})$, compared with 14 of 17 in Monroe Lake and 13 of 20 in Patoka Lake (appendix table 1-5).

Particulate $\mathrm{Hg}$ in water from the Monroe Lake and Patoka Lake reservoirs pools, as a ratio to whole-water $\mathrm{Hg}$ (62 and 68 percent), was higher than in Brookville Lake (44 percent, table 7). Because whole-water $\mathrm{Hg}$ in samples from the Monroe Lake and Patoka Lake pools was predominantly particulate bound, the pattern with depth observed for whole-water $\mathrm{Hg}$ was repeated, and the highest ratios of particulate $\mathrm{Hg}$ were in samples collected below 8- and 9-m depths (appendix table 1-5). Brookville Lake particulate $\mathrm{Hg}$ did not have a pattern with depth. Ratios of particulate $\mathrm{Hg}$ to wholewater $\mathrm{Hg}$ in tailwaters of Monroe Lake and Patoka Lake (55 and 63 percent) were similar to the 58.4-percent mean for the tailwater samples from four reservoirs (table 5).

Whole-water $\mathrm{MeHg}$ was reported in 53 percent (28 of 53) of the samples from the pools and tailwaters of the three reservoirs. At Monroe Lake and Patoka Lake, whole-water $\mathrm{MeHg}$ was detected in 14 of 17 samples and 13 of 20 samples, respectively, but it was in detected in only 1 of 16 samples at Brookville Lake. Dissolved MeHg is the fraction of the dissolved $\mathrm{Hg}$ that is most available for transfer to the aquatic food web. Median and maximum ratios of dissolved $\mathrm{MeHg}$ to $\mathrm{Hg}$ concentrations in samples from the pools of Monroe Lake and Patoka Lake were considerably higher than in those from Brookville Lake (table 7). In Monroe Lake, ratios of dissolved $\mathrm{MeHg}$ to $\mathrm{Hg}$ higher than 25 percent were observed for samples below 8 -m depths in the main lake and near the dam, as well as in the tailwater (fig. 11). In Patoka Lake, ratios of dissolved $\mathrm{MeHg}$ to $\mathrm{Hg}$ higher than 25 percent were observed for all samples below 9-m depths in the main lake, in the Lick Fork inlet, and near the dam (fig. 12). 


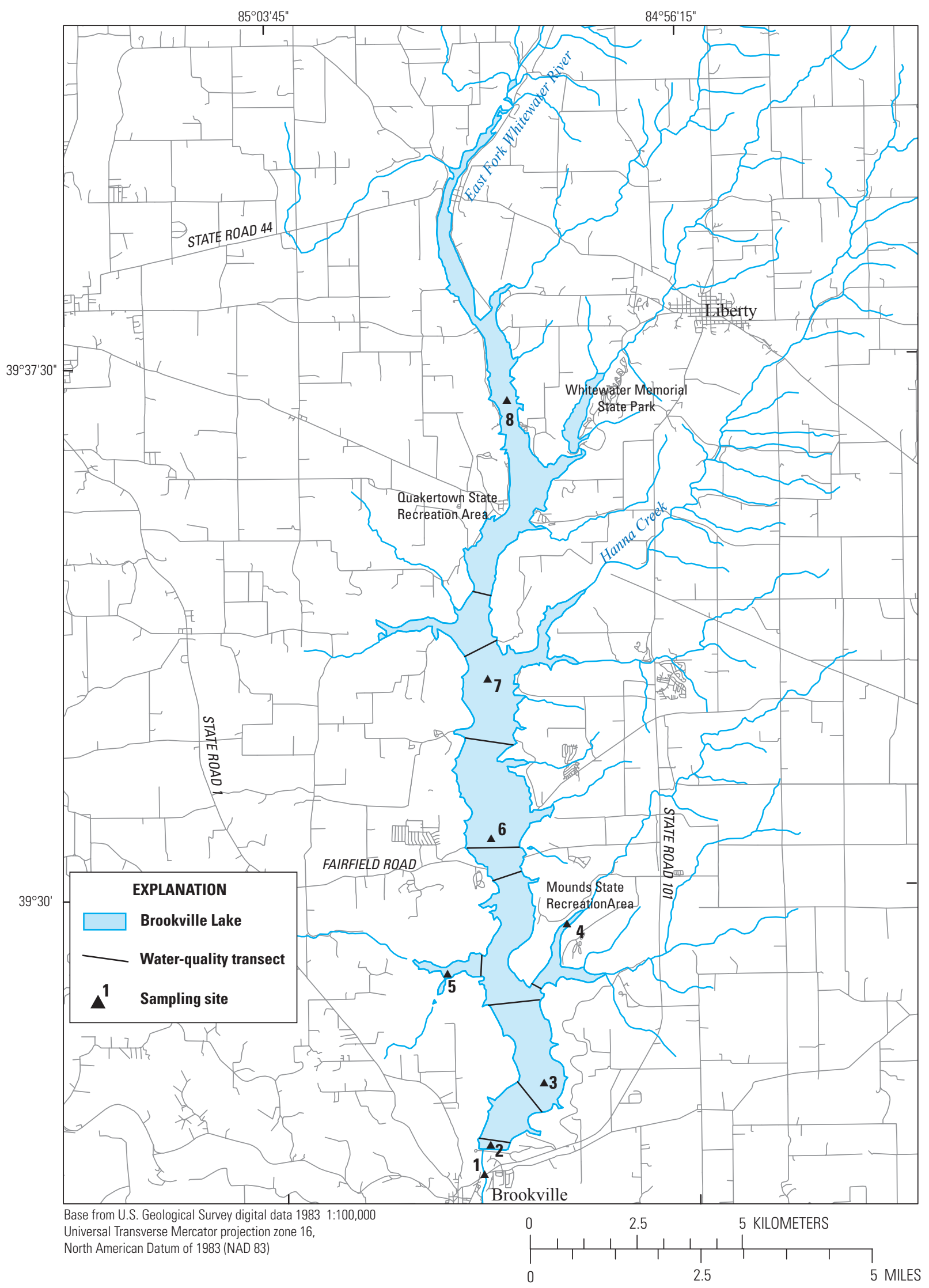

Figure 5. Sampling sites and water-quality transects for Brookville Lake. 


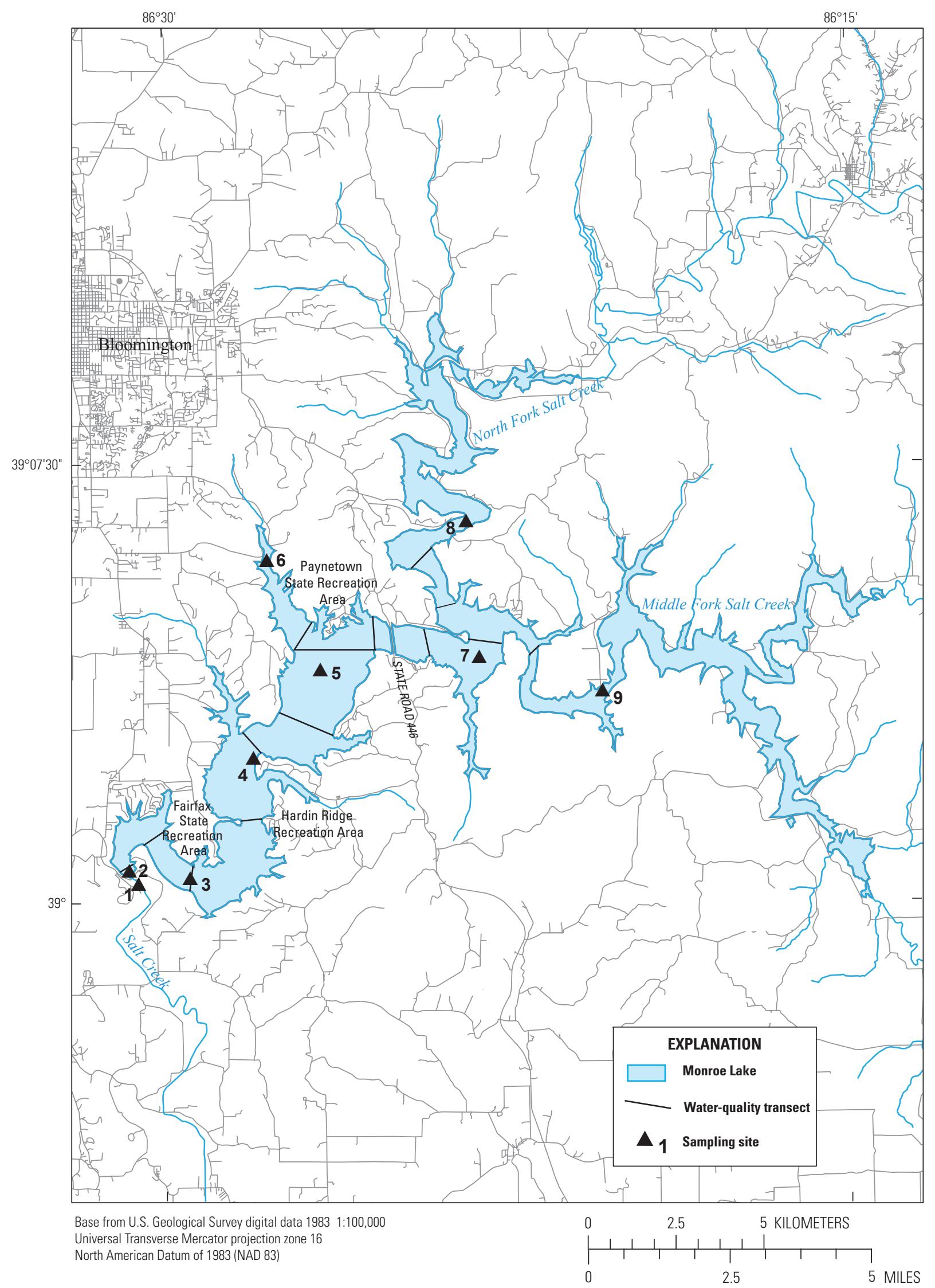

Figure 6. Sampling sites and water-quality transects for Monroe Lake (note variation in horizontal scale). 


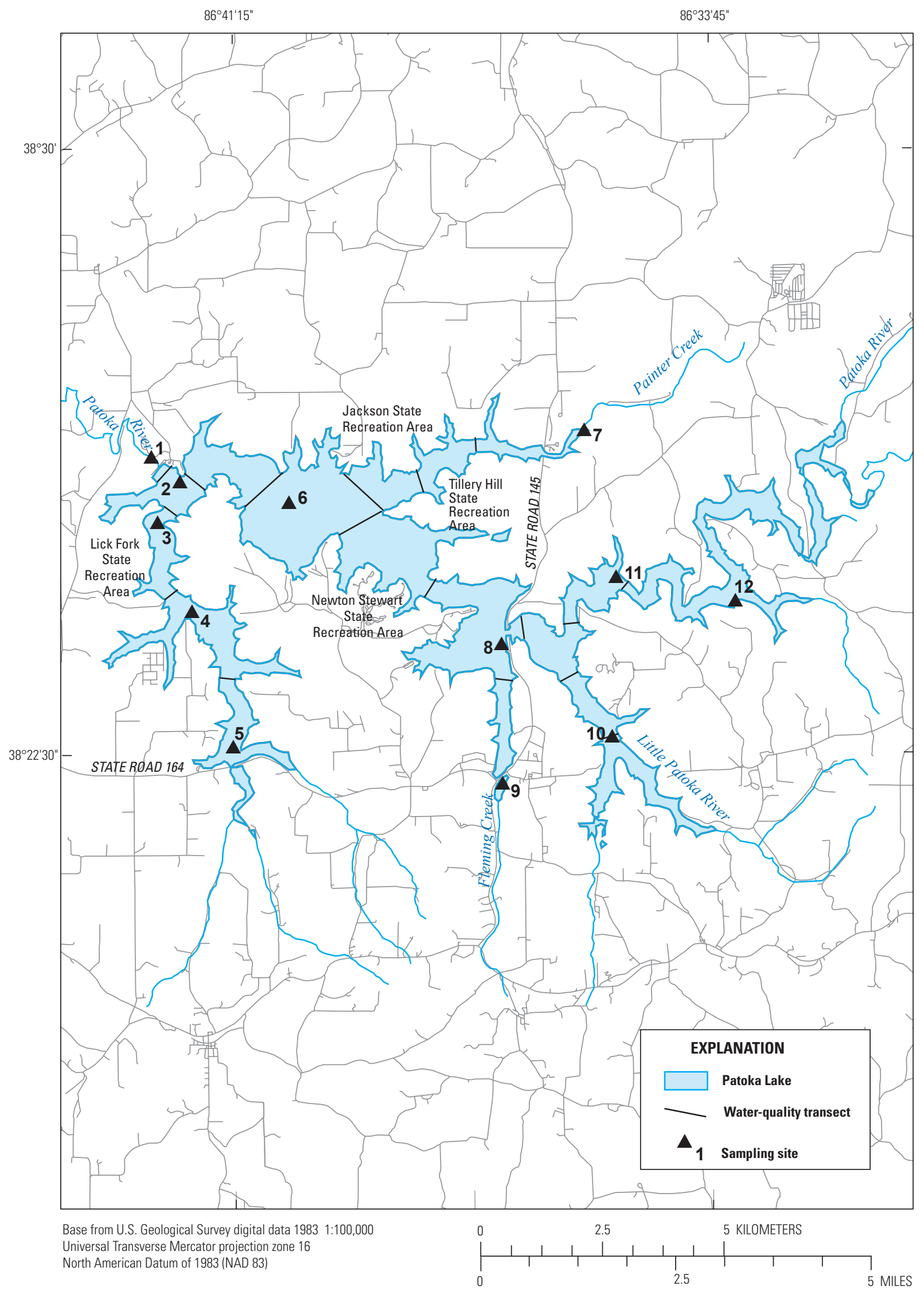

Figure 7. Sampling sites and water-quality transects for Patoka Lake (note variation in horizontal scale). 
Table 6. Reservoir-pool and tailwater sampling-site information.

[NWIS, U.S. Geological Survey National Water Information System database; dms, degree, minute, second]

\begin{tabular}{|c|c|c|c|c|c|c|}
\hline Reservoir & $\begin{array}{c}\text { Site } \\
\text { number }\end{array}$ & Descriptive site name & NWIS Site ID & $\begin{array}{c}\text { Latitude } \\
\text { (dms) }\end{array}$ & $\begin{array}{c}\text { Longitude } \\
\text { (dms) }\end{array}$ & Lake location \\
\hline \multirow[t]{8}{*}{ Brookville Lake } & 1 & Tailwater in East Fork Whitewater River & USGS 03276000 & 392602 & 850012 & Tailwater near gage \\
\hline & 2 & Near dam & USGS 392628084595901 & 392628 & 845959 & Near dam \\
\hline & 3 & Near Bonwell Hill & USGS 392721084585901 & 392721 & 845859 & Main lake, south \\
\hline & 4 & Near Mounds Recreation Area & USGS 392935084583001 & 392935 & 845830 & Inlet, west \\
\hline & 5 & South of Fairfield Road & USGS 392855085004201 & 392855 & 850042 & Inlet, east \\
\hline & 6 & Near Fairfield Marina & USGS 393049084595101 & 393049 & 845951 & Main lake, middle \\
\hline & 7 & Near Hanna Creek Marina & USGS 393304084595101 & 393304 & 845951 & Main lake, north \\
\hline & 8 & Near Quakertown Recreation Area & USGS 393700084592301 & 393700 & 845923 & Headwater \\
\hline \multirow[t]{9}{*}{ Monroe Lake } & 1 & Tailwater in Salt Creek & USGS 03372500 & 390016 & 863031 & Tailwater near gage \\
\hline & 2 & Near dam & USGS 390034086304801 & 390034 & 863048 & Near dam \\
\hline & 3 & Near Fairfax Recreation Area & USGS 390026086292801 & 390026 & 862928 & Main lake, south \\
\hline & 4 & Near Hardin Ridge Recreation Area & USGS 390229086280401 & 390229 & 862804 & Main lake, middle \\
\hline & 5 & Near State Road 446 causeway & USGS 390359086263501 & 390359 & 862635 & Main lake, north \\
\hline & 6 & Near Paynetown Recreation Area & USGS 390552086274501 & 390552 & 862745 & Inlet \\
\hline & 7 & Near Cutright Recreation Area & USGS 390412086230601 & 390412 & 862306 & Main lake, east \\
\hline & 8 & Near Pine Grove Recreation Area & USGS 390631086232201 & 390631 & 862322 & Headwater, north \\
\hline & 9 & Middle Fork Waterfowl Area & USGS 390337086202401 & 390337 & 862024 & Headwater, south \\
\hline \multirow[t]{12}{*}{ Patoka Lake } & 1 & Tailwater in Patoka River & USGS 382618086423301 & 382618 & 864233 & Tailwater \\
\hline & 2 & Near dam & USGS 382553086420601 & 382553 & 864206 & Near dam \\
\hline & 3 & Near Lick Fork Boat Ramp & USGS 382523086422701 & 382523 & 864227 & West branch, north \\
\hline & 4 & Near Lick Fork Recreation Area & USGS 382417086415501 & 382417 & 861550 & West branch, middle \\
\hline & 5 & Near State Road 164 & USGS 382237086411601 & 382337 & 864116 & West branch, south \\
\hline & 6 & Near Newton Stewart Recreation Area & USGS 382538086402301 & 382538 & 864023 & Main lake, middle \\
\hline & 7 & Near Jackson Recreation Area & USGS 382631086354401 & 382631 & 863544 & Inlet, north \\
\hline & 8 & Near Newton Stewart Marina & USGS 382352086370301 & 382352 & 863703 & Main lake, south \\
\hline & 9 & Near State Road 145 at Fleming Creek & USGS 382209086370201 & 382209 & 863702 & Inlet, southwest \\
\hline & 10 & Near Little Patoka River Boat Ramp & USGS 382243086351901 & 382243 & 863719 & Inlet, southwest \\
\hline & 11 & Near Wall's Lake Boat Ramp & USGS 382442086351401 & 382442 & 863514 & Inlet, east \\
\hline & 12 & Near King's Bridge Boat Ramp & USGS 382424086332201 & 382424 & 863322 & Headwater \\
\hline
\end{tabular}


Table 7. Mercury data summary for pools and tailwaters at three reservoirs in Indiana.

$[\mathrm{Hg}$, mercury; MeHg, methylmercury; ng/L, nanogram per liter; < less than percentage listed; n.d., not determined because dissolved MeHg reported in only one sample]

\begin{tabular}{|c|c|c|c|c|c|c|c|c|c|c|}
\hline \multirow[b]{2}{*}{ Reservoir } & \multirow[b]{2}{*}{$\begin{array}{c}\text { Number of } \\
\text { samples }^{1}\end{array}$} & \multicolumn{3}{|c|}{ Whole-water $\mathrm{Hg}^{2}$} & \multicolumn{3}{|c|}{ Ratio of particulate $\mathrm{Hg}$ to $\mathrm{Hg}^{3}$} & \multicolumn{3}{|c|}{ Ratio of dissolved $\mathrm{MeHg}$ to $\mathrm{Hg}^{4}$} \\
\hline & & $\begin{array}{c}\text { Range } \\
\text { in pool } \\
\text { (ng/L) }\end{array}$ & $\begin{array}{c}\text { Median } \\
\text { in pool } \\
\text { (ng/L) }\end{array}$ & $\begin{array}{c}\text { Tailwater } \\
\text { (ng/L) }\end{array}$ & $\begin{array}{c}\text { Range } \\
\text { in pool } \\
\text { (ng/L) }\end{array}$ & $\begin{array}{c}\text { Median } \\
\text { in pool } \\
\text { (ng/L) }\end{array}$ & $\begin{array}{c}\text { Tailwater } \\
\text { (ng/L) }\end{array}$ & $\begin{array}{c}\text { Range } \\
\text { in pool } \\
\text { (ng/L) }\end{array}$ & $\begin{array}{c}\text { Median } \\
\text { in pool } \\
\text { (ng/L) }\end{array}$ & $\begin{array}{c}\text { Tailwater } \\
\text { (ng/L) }\end{array}$ \\
\hline Brookville Lake & 16 & $0.33-1.91$ & 0.56 & 0.31 & $<21-82$ & 41 & $<29$ & 18 & n.d. & n.d. \\
\hline Monroe Lake & 17 & $0.42-4.84$ & 1.36 & 1.92 & $30-79$ & 62 & 55 & $<5-64$ & 20 & 56 \\
\hline Patoka Lake & 20 & $0.42-5.51$ & 1.24 & 0.52 & $25-84$ & 68 & 63 & $<3-82$ & 31 & $<16$ \\
\hline
\end{tabular}

${ }^{1}$ Number of samples includes one tailwater sample and multidepth pool samples.

${ }^{2}$ Whole-water $\mathrm{Hg}$ is the sum of particulate and dissolved $\mathrm{Hg}$ concentrations.

${ }^{3}$ Ratio of particulate $\mathrm{Hg}$ to whole-water $\mathrm{Hg}$ concentration, multiplied by 100 .

${ }^{4}$ Ratio of dissolved MeHg to whole-water MeHg concentration, multiplied by 100, where whole-water MeHg is the sum of the particulate and dissolved fractions. Dissolved MeHg reported in a single sample from Brookville Lake pool. 


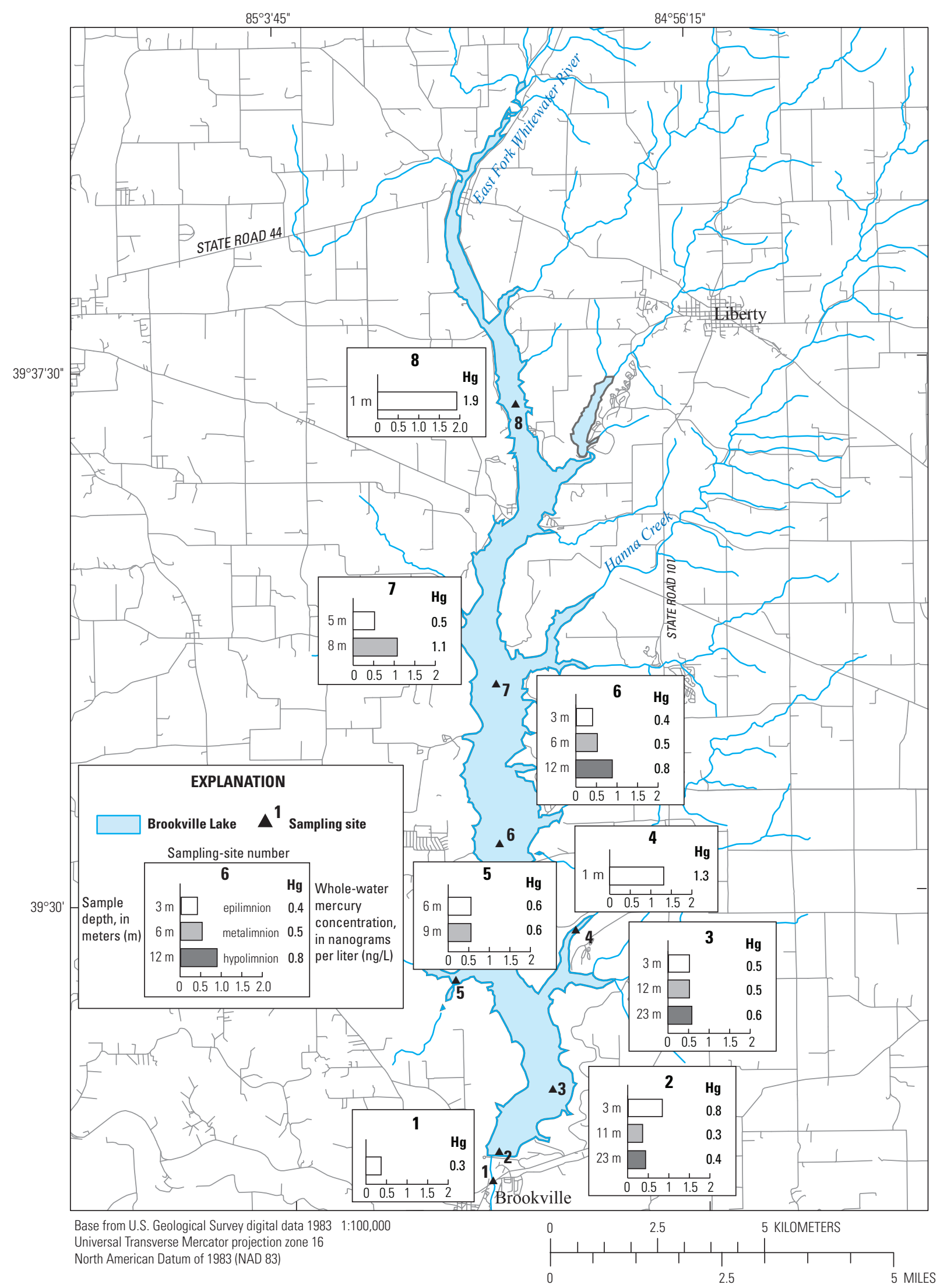

Figure 8. Whole-water mercury concentrations in water from Brookville Lake. (Site 1 was a tailwater site; sample depth not applicable.) 


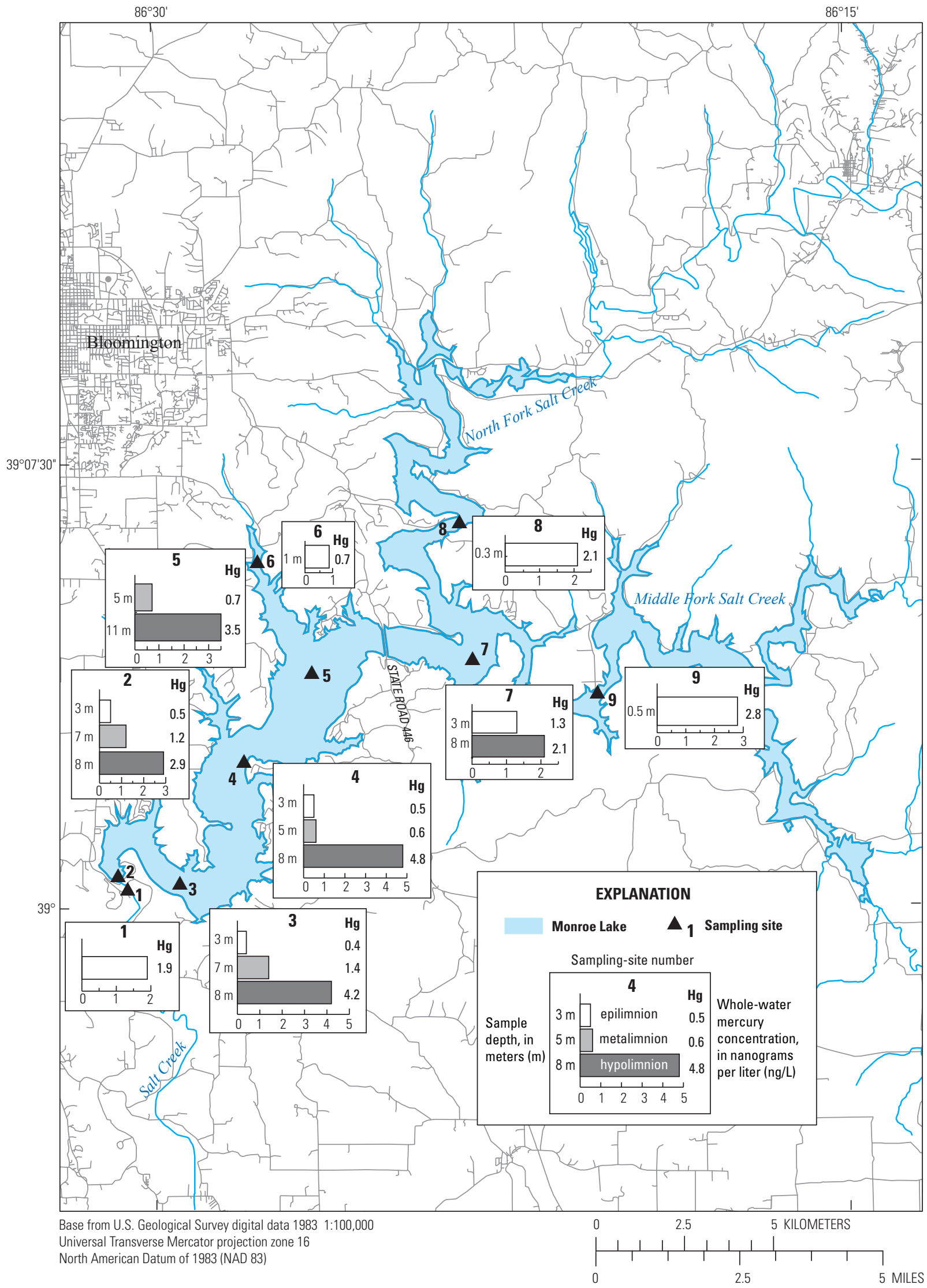

Figure 9. Whole-water mercury concentrations in water from Monroe Lake. (Site 1 was a tailwater site; sample depth not applicable; note variation in horizontal scale.) 


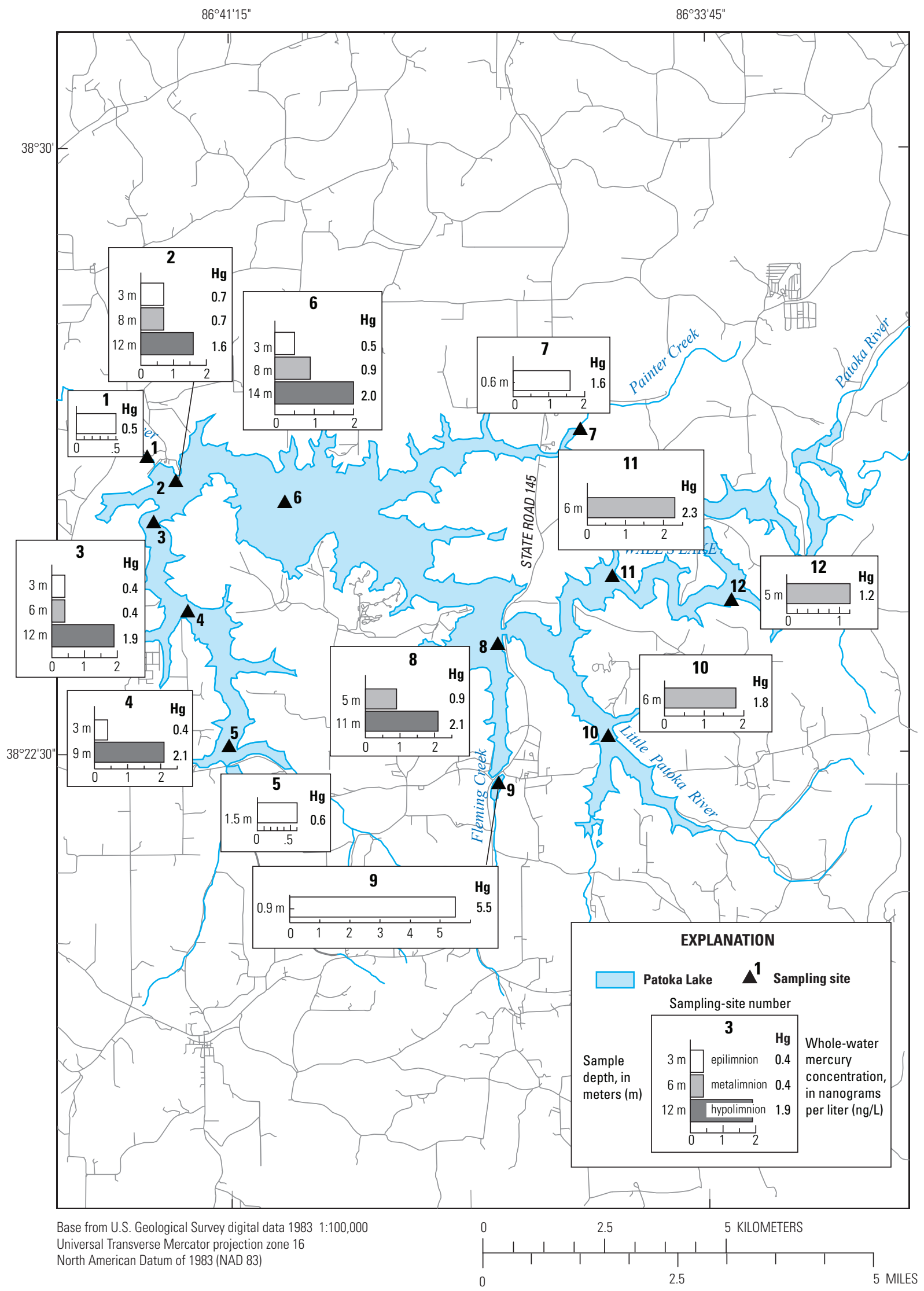

Figure 10. Whole-water mercury concentrations in water from Patoka Lake. (Site 1 was a tailwater site; sample depth not applicable; note variation in horizontal scale.) 


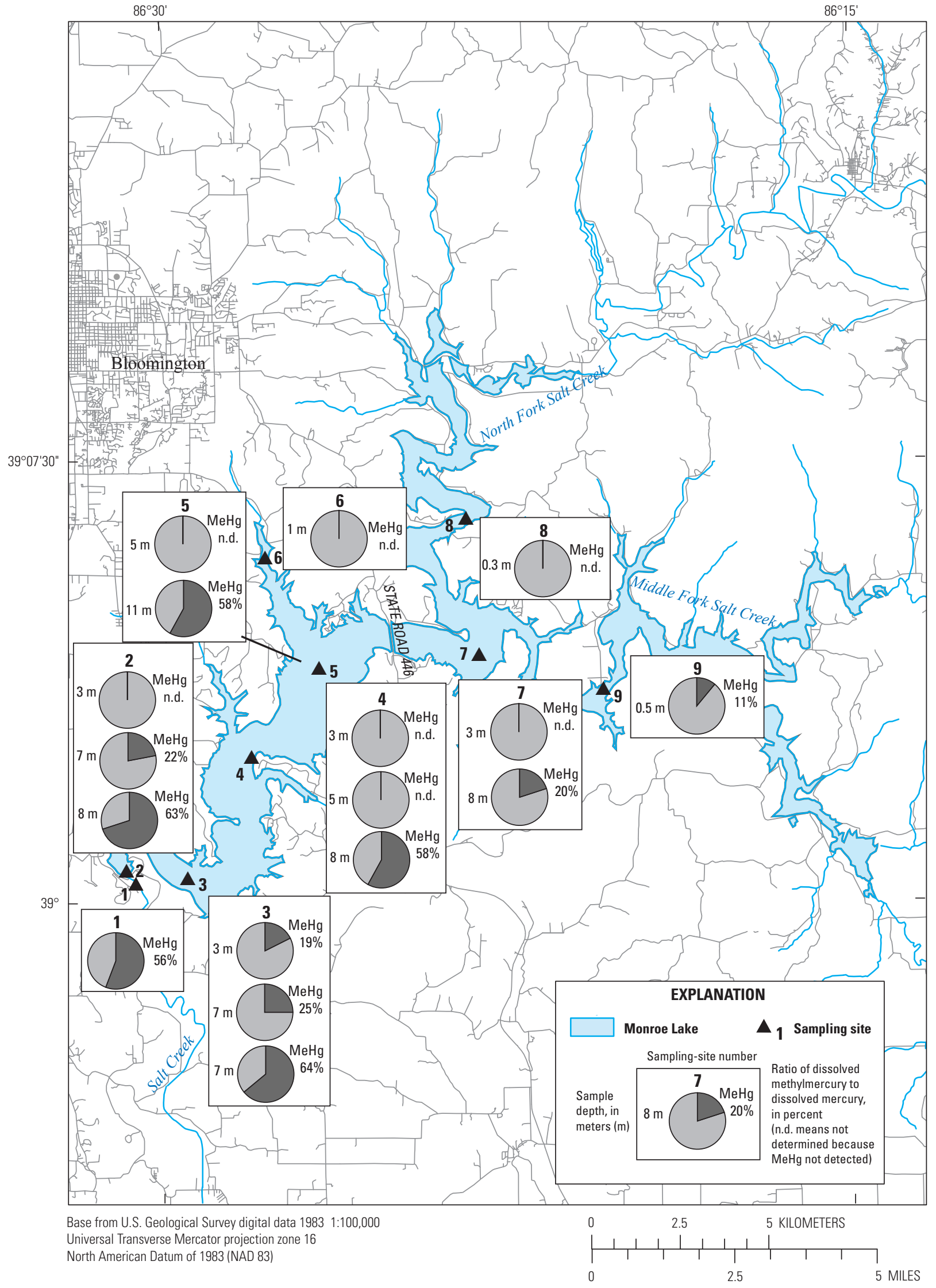

Figure 11. Ratio of dissolved methylmercury to mercury in water from Monroe Lake. 


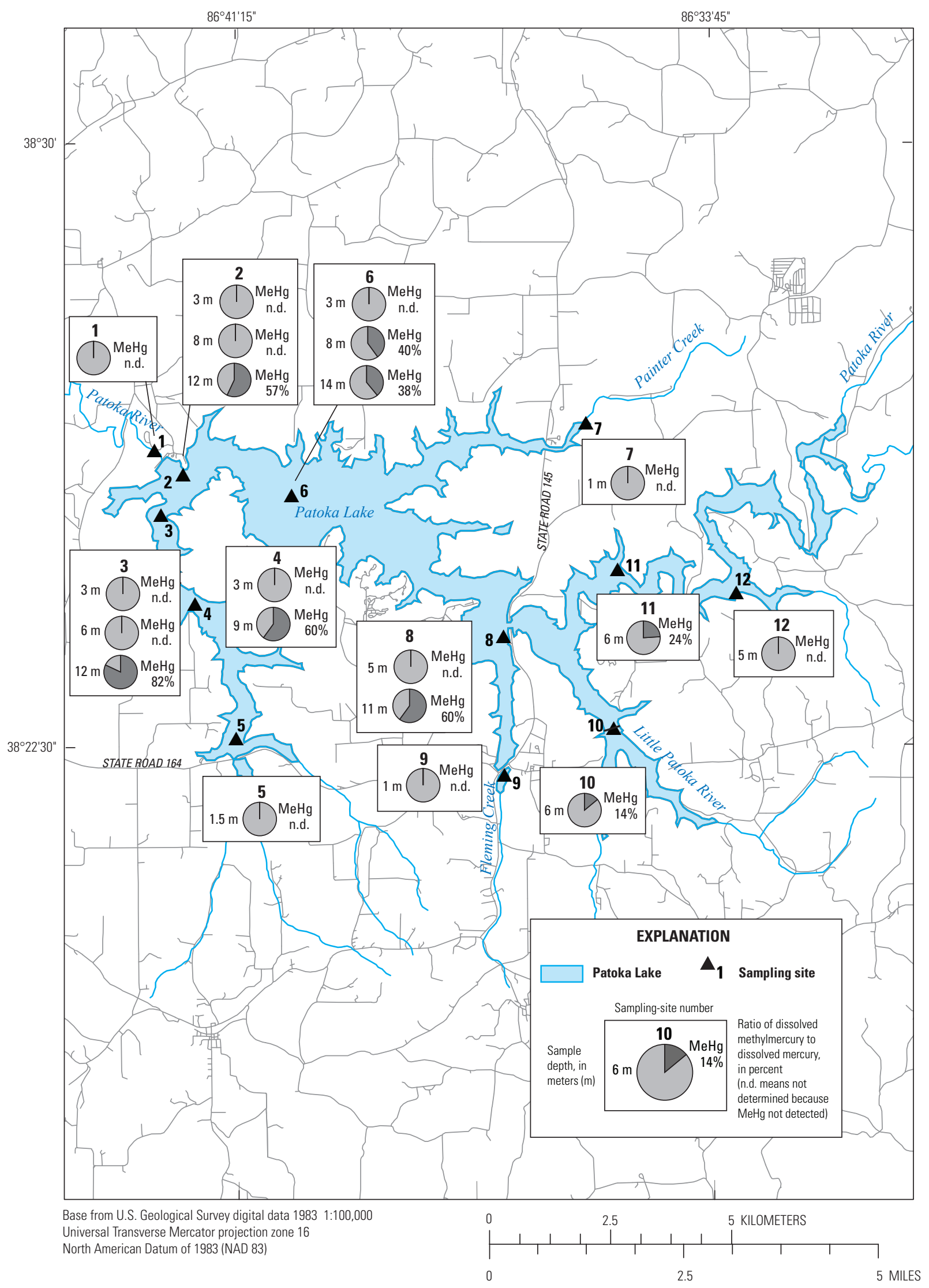

Figure 12. Ratio of dissolved methylmercury to mercury in water from Patoka Lake (note variation in horizontal scale). 


\section{Factors Affecting Mercury and Methylmercury in Reservoirs in Indiana}

Factors affecting $\mathrm{Hg}$ and $\mathrm{MeHg}$ in reservoirs in Indiana are the transport of $\mathrm{Hg}$ and the conversion of $\mathrm{Hg}$ to $\mathrm{MeHg}$. Wet and dry atmospheric deposition rates and landscape characteristics are related to the transport of $\mathrm{Hg}$. Thermal strata and water chemistry are related to the potential for "methylation," which is the conversion of $\mathrm{Hg}$ to $\mathrm{MeHg}$.

\section{Transport of Mercury to Reservoirs}

Wet and dry deposition of atmospheric $\mathrm{Hg}$ are primary pathways for $\mathrm{Hg}$ transport to reservoir watersheds and reservoir pools. For this study, mean annual wet and dry loads of atmospheric $\mathrm{Hg}$ deposited to the reservoir watersheds were computed separately and summed to get a total atmospheric $\mathrm{Hg}$ load to the watershed. The mean annual total Hg-deposition rate for each reservoir watershed was computed by dividing the total $\mathrm{Hg}$ load by the drainage area. StreamStats (U.S. Geological Survey, 2011) was used to delineate the watershed and quantify the drainage area upstream from each reservoir dam. Explanations of wet and dry $\mathrm{Hg}$ deposition follow.

Mean annual $\mathrm{Hg}$ wet-deposition rates in Indiana were mapped as the product of $\mathrm{Hg}$ concentrations in precipitation monitored at 9 sites in Indiana and 4 nearby states and precipitation amounts monitored at 151 sites in Indiana, 2001-2006, by using the method described in Risch and others (2010). Mean annual $\mathrm{Hg}$ wet-deposition loads for each reservoir watershed were computed as a product of the $\mathrm{Hg}$-deposition rates on the map and the drainage area upstream from the reservoir.

Mean annual $\mathrm{Hg}$ dry-deposition rates were based on the 3-year mean annual litterfall $\mathrm{Hg}$-deposition rate at four sites in Indiana, 2007-2009 (Risch and others, 2012). Studies have shown that forest canopies scavenge and retain $\mathrm{Hg}$ from the air and that forests are net sinks for dry deposition of atmospheric Hg (Kolka and others, 1999; Grigal, 2002; Hartman and others, 2009, Zhang and others, 2009). Annual litterfall Hg deposition in a deciduous forest is a conservative estimate of the $\mathrm{Hg}$ dry deposition to the forest canopy (Risch and others, 2012, Zhang and others 2012).

By use of ArcGIS software (Environmental Systems Research Institute, 2006), the watershed for each reservoir was overlain on the National Land Cover Database (NLCD; Homer and others, 2004) and the area in each of the NLCD land-cover classes was computed (appendix table 1-6). Deciduous, evergreen, and mixed NLCD forest classes were combined to get the area of forest land cover in the watershed. Mean annual $\mathrm{Hg}$ dry-deposition loads for each reservoir watershed were computed as a product of the mean annual litterfall $\mathrm{Hg}$-deposition rate and the area of forest land cover in the reservoir.
For the reservoirs in Indiana, the mean annual total $\mathrm{Hg}$-deposition rates ranged from 11.3 to 25.7 micrograms per square meter $\left(\mathrm{mg} / \mathrm{m}^{2}\right)$ (appendix table 1-7) and were highest for Monroe Lake and Patoka Lake. Mercury wet deposition and litterfall $\mathrm{Hg}$ dry deposition tend to correlate spatially and statistically (Risch and others, 2012), and the same Hg emissions sources may affect $\mathrm{Hg}$ wet and dry deposition. Mean annual $\mathrm{Hg}$ wet-deposition rates were highest for Monroe Lake and Patoka Lake (12 to13 mg/m²). Forest land cover was highest for Monroe Lake (for 82 percent) and Patoka Lake (67 percent), whereas forest in the other six reservoirs was less than 23 percent. A full comparison of $\mathrm{Hg}$ deposition and reservoir-pool $\mathrm{Hg}$ could not be made for all the reservoirs in Indiana with the available data.

Classifications of physiography, natural region, and surficial geology indicated that three reservoirs-Monroe Lake, Patoka Lake, and Cagles Mill Lake_-are in landscapes with steep slopes and near-surface bedrock that promote high rates of precipitation runoff and low rates of infiltration. These landscapes have potentially higher rates of particulate and dissolved $\mathrm{Hg}$ transport to reservoirs than occurs in flat topography with glacial deposits. These three reservoirs also have the highest mean annual total $\mathrm{Hg}$-deposition rates. Monroe Lake, Patoka Lake, and Cagles Mill Lake are in the Southern Hills and Lowlands physiographic region and the Shawnee Hills and Southern Bottomlands natural region; their surficial geology is primarily sandstone, shale, and limestone bedrock (table 8). The other five reservoirs are in the Central Till Plain physiographic and natural regions; the surficial geology is predominantly loamy till, outwash, and alluvium.

\section{Conversion of Mercury to Methylmercury in Reservoirs}

Three layers (called thermal strata) were defined for discussion in this study, based on water temperature, dissolved oxygen, and water depth determined from vertical profiles along 10 to 17 transects in each reservoir pool. The three thermal strata are the following:

1. The epilimnion, a surface layer with water temperatures greater than 23 degrees Celsius $\left({ }^{\circ} \mathrm{C}\right)$, dissolved oxygen greater than 7 milligrams per liter $(\mathrm{mg} / \mathrm{L})$, and water depth less than $5 \mathrm{~m}$.

2. The metalimnion, a transition layer with water temperatures 20 to $23^{\circ} \mathrm{C}$, dissolved oxygen 4 to $7 \mathrm{mg} / \mathrm{L}$, and water depth 2 to $3 \mathrm{~m}$ below the epilimnion.

3. The hypolimnion, the layer extending to the lake bottom, with water temperatures less than $20^{\circ} \mathrm{C}$, dissolved oxygen less than $4 \mathrm{mg} / \mathrm{L}$, and the greatest water depths. 
Table 8. Physiographic region, natural region, and surficial geology in the vicinity of reservoirs in Indiana.

\begin{tabular}{|c|c|c|c|}
\hline Reservoir & Physiographic region & Natural region & Surficial (Quaternary) geology \\
\hline Brookville Lake & Central Till Plain & Bluegrass, Central Till Plain & $\begin{array}{l}\text { Loam of Wisconsinan till; Ordovician shale } \\
\text { and limestone }\end{array}$ \\
\hline C.M. Harden Lake & Central Till Plain & Central Till Plain, Shawnee Hills & $\begin{array}{l}\text { Loam to sandy loam of pre-Wisconsinan till; } \\
\text { alluvium }\end{array}$ \\
\hline Monroe Lake & Southern Hills and Lowlands & Shawnee Hills, Highland Rim & $\begin{array}{l}\text { Mississippian siltstone, limestone, shale, and } \\
\text { terra rossa }\end{array}$ \\
\hline Patoka Lake & Southern Hills and Lowlands & Shawnee Hills, Southern Bottomlands & $\begin{array}{l}\text { Mississippian and Pennsylvanian sandstone, } \\
\text { shale, and limestone }\end{array}$ \\
\hline J.E. Roush Lake & Central Till Plain & Central Till Plain & Silty clay loam of Wisconsinan till \\
\hline
\end{tabular}

Information about the following classifications were obtained from metadata at Indiana Geological Survey (2011).

${ }^{1}$ Physiographic region from Indiana Geological Survey (Gray, 2000).

${ }^{2}$ Natural region from Indiana Department of Natural Resources, Division of Nature Preserves, Indiana Natural Heritage Data Center (Homoya and others, 1985).

${ }^{3}$ Quaternary geology from Indiana Geological Survey (Gray, 1989).

Reservoir-pool MeHg concentrations and ratios of dissolved $\mathrm{MeHg}$ to $\mathrm{Hg}$ in samples from Monroe Lake and Patoka Lake $^{9}$ demonstrated a significant correlation with sample depth $(r h o>0.7)$, and a significant inverse correlation with dissolved oxygen $(r h o>-0.6)$ and water temperature $(r h o>-0.7)$ (fig. 13, table 9). These correlations indicate that deep, relatively cold, relatively low-dissolved-oxygen water, found primarily in the hypolimnion and in part of the metalimnion, coincided with the highest $\mathrm{Hg}$ and $\mathrm{MeHg}$ concentrations and ratios of $\mathrm{MeHg}$ to Hg. Water-sample data indicate that methylation probably was occurring in or near the hypolimnion because this stratum had the highest ratios of dissolved $\mathrm{MeHg}$ to $\mathrm{Hg}$. The data do not confirm whether methylation was occurring in the water column, in the lake-bottom sediment, at the sediment-water interface, or some combination of these locations.

Statistical differences between $\mathrm{Hg}, \mathrm{MeHg}$, and water quality in the hypolimnion and epilimnion were observed in Monroe Lake and Patoka Lake. These differences were evaluated by grouping samples by the three thermal strata and tailwater.

In Monroe Lake, the hypolimnion had significantly higher concentrations of particulate $\mathrm{Hg}$, dissolved $\mathrm{Hg}$, particulate $\mathrm{MeHg}$, and dissolved $\mathrm{MeHg}$ and a higher ratio of dissolved $\mathrm{MeHg}$ to $\mathrm{Hg}$ than the epilimnion (Kruskal-Wallis, $\mathrm{p}<0.05$ ). The hypolimnion had significantly lower dissolved oxygen, water $\mathrm{pH}$, and dissolved sulfate than the epilimnion (Kruskal-Wallis, $\mathrm{p}<0.05$ ). The tailwater had dissolved $\mathrm{Hg}$ and $\mathrm{MeHg}$, a ratio of dissolved $\mathrm{MeHg}$ to $\mathrm{Hg}$, dissolved oxygen, water $\mathrm{pH}$, and dissolved sulfate that were most similar to those of the hypolimnion (fig. 14).

\footnotetext{
${ }^{9}$ Correlations were not computed for Brookville Lake because MeHg was detected once in the samples from the reservoir pool.
}

In Patoka Lake, the hypolimnion had significantly higher concentrations of particulate and dissolved $\mathrm{MeHg}$ and a higher ratio of $\mathrm{MeHg}$ to $\mathrm{Hg}$ than the epilimnion (Kruskal-Wallis, $\mathrm{p}<0.05$ ). The hypolimnion had significantly lower dissolved oxygen, water $\mathrm{pH}$, and dissolved sulfate than the epilimnion (Kruskal-Wallis, $\mathrm{p}<0.05$ ). The tailwater had dissolved $\mathrm{Hg}$ and $\mathrm{MeHg}$, a ratio of dissolved $\mathrm{MeHg}$ to $\mathrm{Hg}$, dissolved oxygen, and water $\mathrm{pH}$ that were most similar to those of the epilimnion (fig. 15).

Through the preceding analysis, the hypolimnions of Monroe Lake and Patoka Lake were found to have zones of high methylation potential - defined by water temperature less than $18.5^{\circ} \mathrm{C}$, dissolved oxygen less than $3.5 \mathrm{mg} / \mathrm{L}$, and water depths greater than $8 \mathrm{~m}$. The estimated areal extent of these zones involved nearly half of the summer pools in Monroe Lake (fig. 16) and Patoka Lake (fig. 17). The extents of these zones were estimated with values of water temperature and dissolved oxygen measured along the vertical profiles of the 31 water-quality transects and were processed with GIS software to interpolate the areal extent of similar values.

Alpers and others (2008) discussed (1) how seasonal thermal stratification in reservoirs with a hypolimnion that has low dissolved oxygen can promote $\mathrm{MeHg}$ formation in deep water and lake-bottom sediments and (2) how the $\mathrm{MeHg}$ becomes vertically mixed into all the water during thermal destratification. Gray and Hines (2009) confirmed that methylation is highly influenced by a eutrophic hypolimnion with low concentrations of dissolved oxygen, geochemically reducing conditions, high organic matter in bottom sediment, and high concentrations of dissolved plant nutrients that increases the activity of $\mathrm{Hg}$-methylating anaerobic organisms and increases the $\mathrm{MeHg}$ flux at the water-sediment interface. 

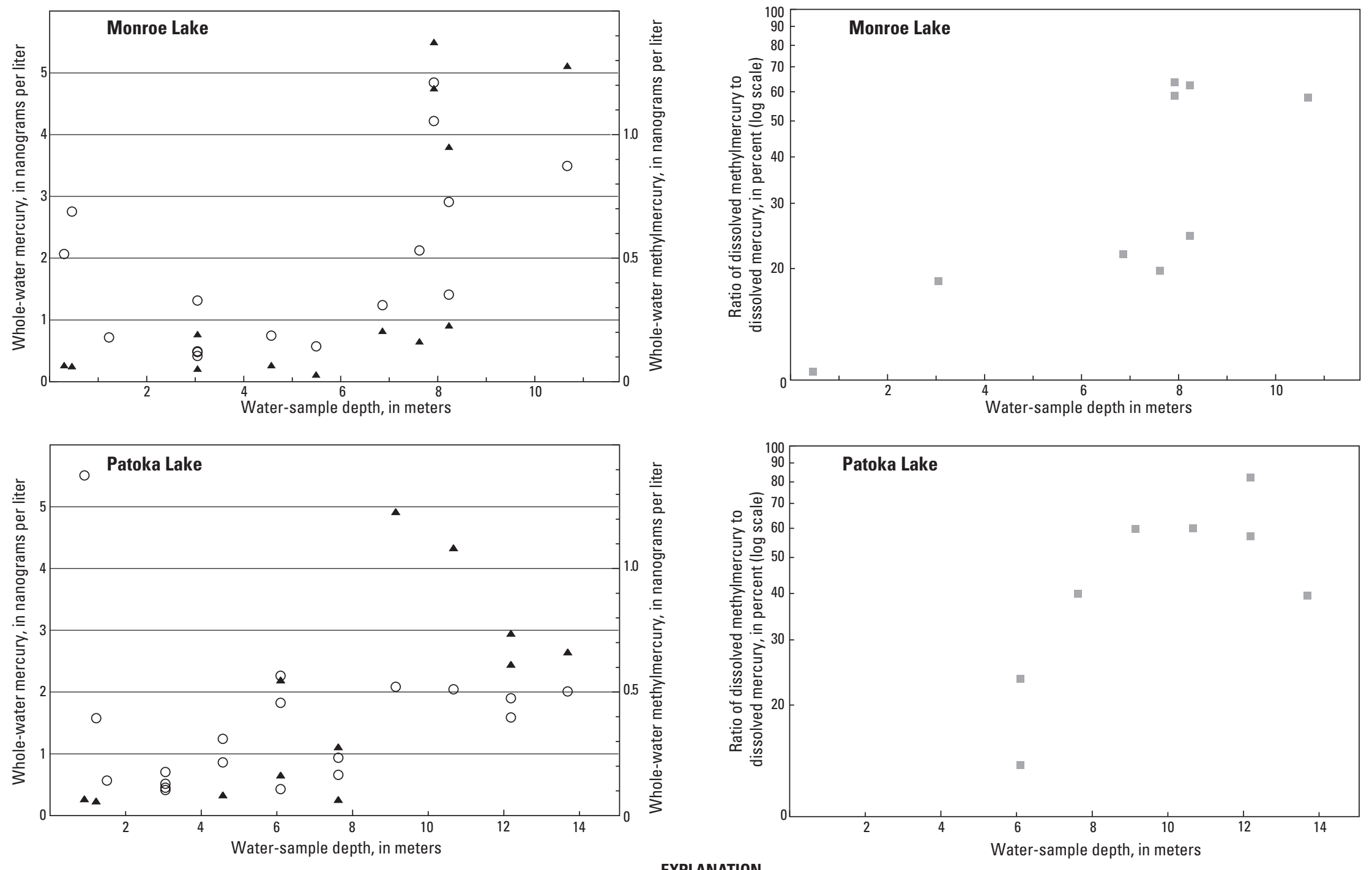

O Whole-water mercury concentration

A Whole-water methylmercury concentration

- Ratio of dissolved methylmercury to dissolved mercury (percent)

Figure 13. Relations between mercury and sample depth in Monroe Lake and Patoka Lake. 
Table 9. Statistical correlations of reservoir pool mercury with sample depth and selected constituents in Monroe Lake and Patoka Lake.

[Spearman rank correlation test significance (p-value < 0.05) in bold; rho, Spearman rank correlation coefficient; Hg, mercury; MeHg, methylmercury; DOC, dissolved organic carbon]

\begin{tabular}{|c|c|c|c|c|c|c|c|c|c|c|c|c|c|}
\hline \multirow{2}{*}{ Reservoir } & \multirow{2}{*}{ Mercury determination } & \multicolumn{2}{|c|}{ Sample depth } & \multicolumn{2}{|c|}{ Dissolved oxygen } & \multicolumn{2}{|c|}{ Water pH } & \multicolumn{2}{|c|}{ Water temperature } & \multicolumn{2}{|c|}{ Dissolved sulfate } & \multicolumn{2}{|c|}{ DOC } \\
\hline & & p-value & rho & p-value & rho & p-value & rho & p-value & rho & p-value & rho & p-value & rho \\
\hline \multirow[t]{4}{*}{ Monroe Lake } & $\mathrm{Hg}_{\text {concentration }}{ }^{1}$ & 0.044 & 0.521 & 0.156 & -0.368 & 0.001 & -0.822 & 0.008 & -0.688 & $<0.001$ & -0.900 & 0.007 & 0.702 \\
\hline & $\mathrm{MeHg}$ concentration ${ }^{2}$ & 0.003 & 0.763 & 0.020 & -0.600 & 0.001 & -0.854 & 0.001 & -0.935 & $<0.001$ & -0.872 & 0.070 & 0.470 \\
\hline & Ratio of $\mathrm{MeHg}$ to $\mathrm{Hg}^{3}$ & 0.002 & 0.818 & 0.006 & -0.708 & 0.002 & -0.783 & 0.002 & -0.814 & 0.004 & -0.749 & 0.181 & 0.347 \\
\hline & Ratio of dissolved $\mathrm{MeHg}$ to $\mathrm{Hg}^{4}$ & 0.002 & 0.787 & 0.003 & -0.752 & 0.002 & -0.791 & 0.006 & -0.710 & 0.005 & -0.731 & 0.083 & 0.449 \\
\hline \multirow[t]{4}{*}{ Patoka Lake } & $\mathrm{Hg}_{\text {concentration }}{ }^{1}$ & 0.120 & 0.368 & 0.003 & -0.690 & 0.002 & -0.731 & 0.004 & -0.684 & 0.009 & -0.617 & 0.064 & 0.437 \\
\hline & $\mathrm{MeHg}$ concentration $^{2}$ & 0.001 & 0.757 & $<0.001$ & -0.790 & $<0.001$ & -0.827 & $<0.001$ & -0.849 & 0.002 & -0.734 & 0.883 & 0.035 \\
\hline & Ratio of $\mathrm{MeHg}$ to $\mathrm{Hg}^{3}$ & $<0.001$ & 0.792 & $<0.001$ & -0.800 & $<0.001$ & -0.855 & $<0.001$ & -0.852 & 0.002 & -0.725 & 0.775 & -0.068 \\
\hline & Ratio of dissolved $\mathrm{MeHg}$ to $\mathrm{Hg}^{4}$ & $<0.001$ & 0.818 & 0.002 & -0.714 & 0.002 & -0.726 & $<0.001$ & -0.822 & 0.004 & -0.674 & 0.893 & -0.032 \\
\hline
\end{tabular}

Whole-water concentration determined as particulate plus dissolved concentration.

${ }^{2}$ Whole-water concentration determined as particulate plus dissolved concentration.

${ }^{3}$ Ratio of whole-water methylmercury to whole-water mercury concentration.

${ }^{4}$ Ratio of dissolved methylmercury to dissolved mercury concentration. 

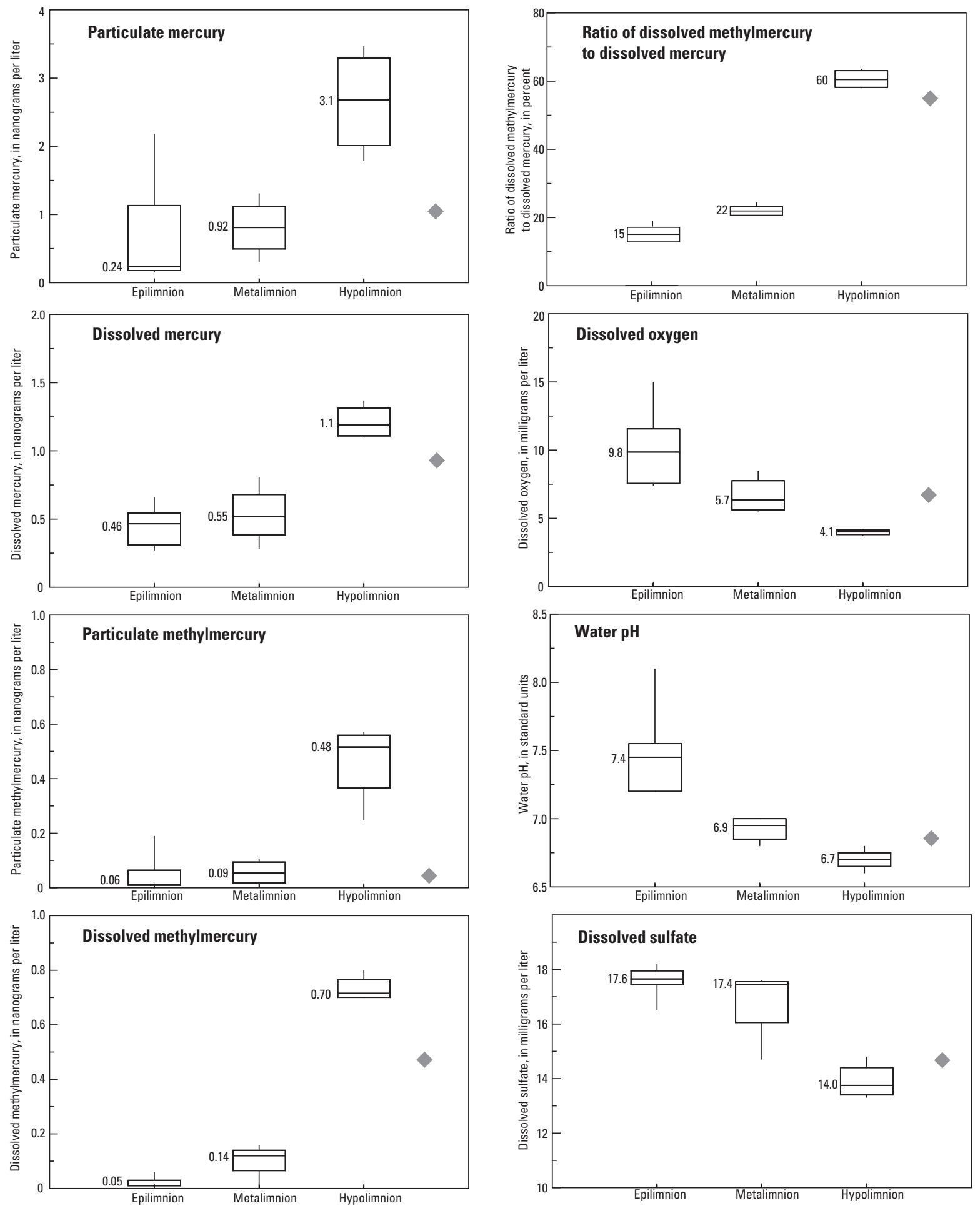

EXPLANATION

(Box height is variation or spread of data values, also called the interquartile range; one step equals 1.5 times the height of the box. Whisker includes adjacent values within one step above or below box

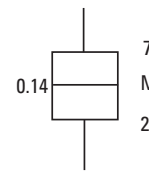

75th percentile (top of box) Median (50th percentile) Value shown

Number of values Epilimnion (8) Metalimnion (4) Hypolimnion (4) Tailwater (1)

Figure 14. Distributions of mercury, methylmercury, dissolved oxygen, water pH, and dissolved sulfate in Monroe Lake. 

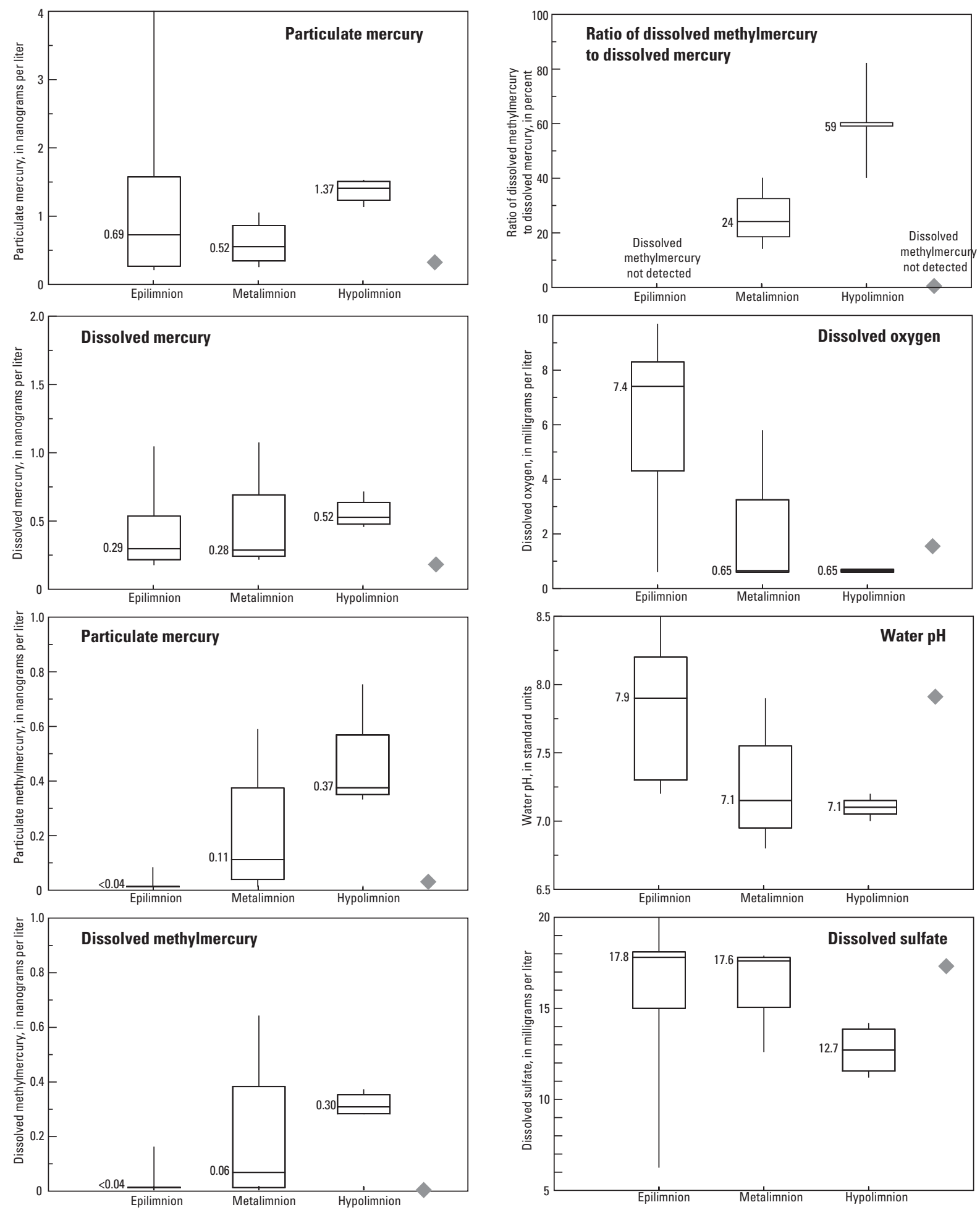

\section{EXPLANATION}

(Box height is variation or spread of data values, also called the interquartile range; one step equals 1.5 times the height of the box. Whisker includes

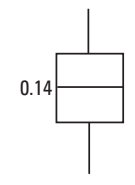

75th percentile (top of box) Median (50th percentile) Value shown Number of values
Epilimnion (9)
Metalimnion (5)
Hypolimnion (4)
Tailwater (1)

Tailwater value 25th percentile (bottom of box)

Figure 15. Distributions of mercury, methylmercury, dissolved oxygen, water pH, and dissolved sulfate in Patoka Lake. 


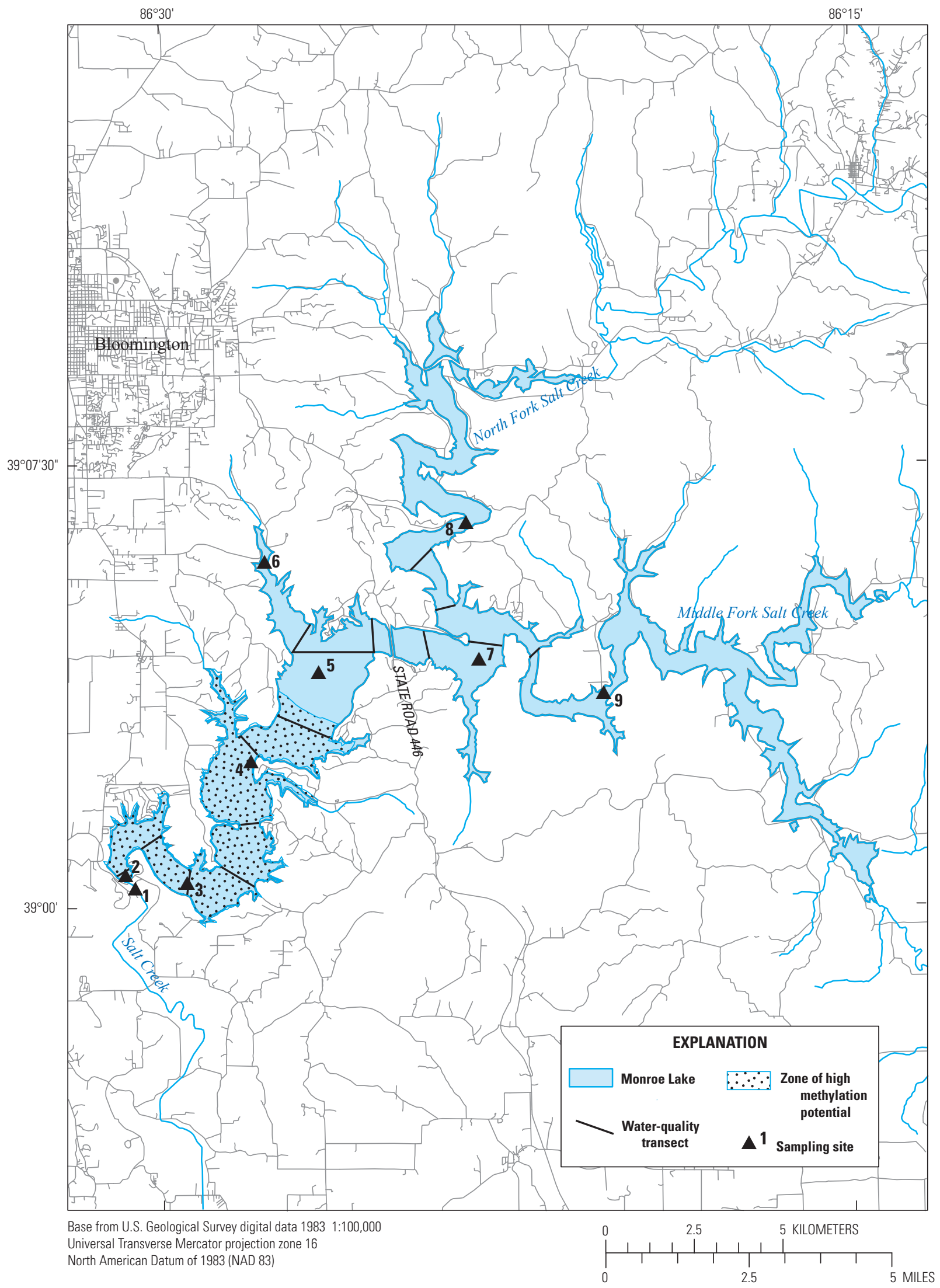

Figure 16. Areal extent of zone of high methylation potential in summer pool of Monroe Lake. 


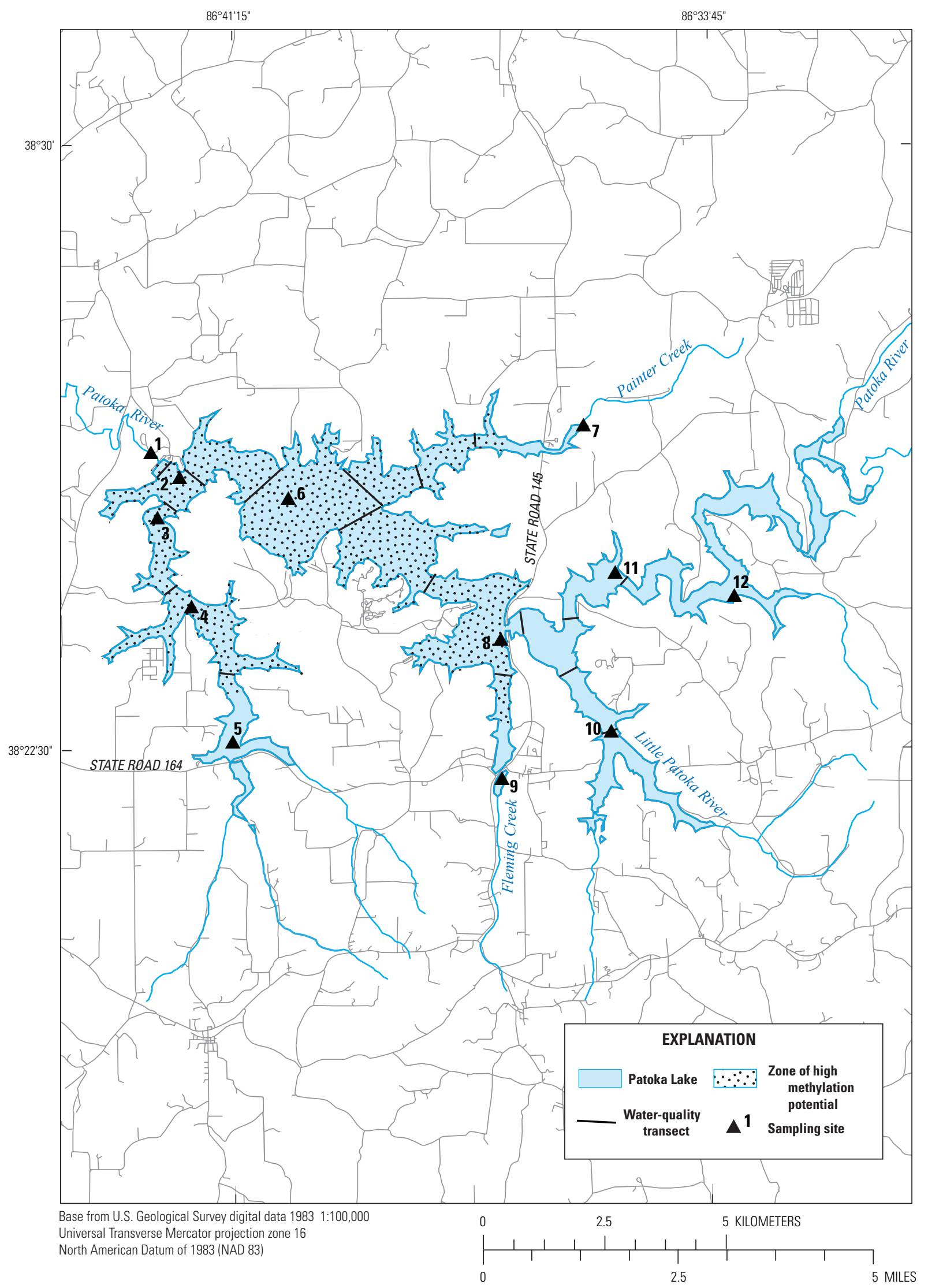

Figure 17. Areal extent of zone of high methylation potential in summer pool of Patoka Lake. 
The summer pools of Monroe Lake (59.5 kilometers [km] long) and Patoka Lake (40.2 km long) are the longest in Indiana (table 1). The mean annual retention times, which are based on reservoirs outflows and pool volume for 1984-2007, index the time for water to move through each reservoir (table 1). The highest retention times in Indiana include Patoka Lake (556 days) and Monroe Lake (199 days). A long summer pool and high retention time apparently combine to retain $\mathrm{Hg}$ when the extensive zone of high methylation potential develops in Monroe Lake and Patoka Lake. These reservoir characteristics may be related to the maximum ratios of 64 to 82 percent dissolved $\mathrm{MeHg}$ to $\mathrm{Hg}$ measured in Monroe Lake and Patoka Lake.

The concentrations of $\mathrm{Hg}$ and $\mathrm{MeHg}$ and the ratios of whole-water $\mathrm{MeHg}$ to $\mathrm{Hg}$ and dissolved $\mathrm{MeHg}$ to $\mathrm{Hg}$ in Monroe Lake and Patoka Lake demonstrated a significant inverse correlation with water $\mathrm{pH}($ rho $>-0.7)$ and concentrations of dissolved sulfate (rho $>-0.6)$ and dissolved oxygen ( $r h o>-0.6$, except $r h o>-0.37$ for $\mathrm{Hg}$ in Monroe Lake) (table 9). ${ }^{10}$ Values for water $\mathrm{pH}$, dissolved sulfate, and dissolved oxygen were lower in the hypolimnion than the metalimnion and the epilimnion of both reservoirs (figs. 14 and 15). Decreased concentrations of dissolved sulfate and increased hydrogen sulfide are indications of sulfate reduction. The odor of hydrogen sulfide was reported in all water samples from the hypolimnions of Monroe Lake and Patoka Lake, which coincided with the lowest concentrations of dissolved sulfate. Microorganisms including bacteria that reduce sulfate to hydrogen sulfide are thought to facilitate $\mathrm{Hg}$ methylation.

The role of water $\mathrm{pH}$ for methylation potential in the reservoir pools is shown by comparing conditions at Brookville Lake with Monroe Lake and Patoka Lake. At Brookville Lake, $\mathrm{MeHg}$ was not detected in samples from the reservoir pool even though whole-water $\mathrm{Hg}$ was detected in all water samples. Water $\mathrm{pH}$ in Brookville Lake was statistically higher in all water samples compared to Monroe Lake and Patoka Lake and also was higher in the hypolimnion samples (median 7.6) compared to Monroe Lake and Patoka Lake (median 6.7 and 7.1, respectively). Dissolved sulfate in Brookville Lake was statistically higher in all water samples compared to Monroe Lake and Patoka Lake and also was higher in the hypolimnion samples (median $25.5 \mathrm{mg} / \mathrm{L}$ ) compared to Monroe Lake and Patoka Lake (median 13.8 and $12.7 \mathrm{mg} / \mathrm{L}$, respectively). These data indicate a potential relation of the lower sulfate reduction in the Brookville Lake hypolimnion with the relatively higher $\mathrm{pH}$ water.

Particulate organic carbon (POC) and dissolved organic carbon (DOC) provide a substrate for particulate $\mathrm{Hg}$ and sulfate-reducing microorganisms. Both POC and DOC were detected in water from both reservoirs. However, DOC was significantly correlated only with whole-water $\mathrm{Hg}$ in samples from Monroe Lake (table 9). The DOC concentrations in the Monroe Lake hypolimnion samples were significantly

\footnotetext{
${ }^{10}$ Correlations were not computed for Brookville Lake because $\mathrm{MeHg}$ was detected once in the samples from the reservoir pool.
}

higher (median $4.4 \mathrm{mg} / \mathrm{L}$ ) than those in Patoka Lake (median $3.1 \mathrm{mg} / \mathrm{L}$ ). Concentrations of DOC in Brookville Lake water samples were not statistically different from those in Patoka Lake, whether all samples or hypolimnion samples are considered. Overall, POC and DOC were less important for explaining methylation potential in the reservoir pools than were dissolved sulfate and water $\mathrm{pH}$.

\section{Reservoir Fish}

\section{Concentrations in Fish Tissue}

Methylmercury (reported as $\mathrm{Hg}$ ) in fish-tissue samples was used to depict the effects of $\mathrm{MeHg}$ food-web accumulation and magnification in the reservoirs. Data for $\mathrm{Hg}$ concentrations in 203 fish-tissue samples were compiled for the eight reservoirs in Indiana (appendix table 1-8) and were compared with the reference benchmarks for human health and for wildlife. The wet-weight fish-tissue $\mathrm{Hg}$ concentrations in these 203 samples ranged from 0.02 to $0.91 \mathrm{mg} / \mathrm{kg}$, and the median was $0.16 \mathrm{mg} / \mathrm{kg}$. Concentrations in 19 percent of the samples exceeded $0.30 \mathrm{mg} / \mathrm{kg}$ - a percentage approximately equal to 1 out of every 5 fish samples, compared with 1 out of every 8 fish samples in rivers, streams, lakes, and reservoirs statewide (Risch and others, 2010).

Mercury concentrations that exceeded $0.30 \mathrm{mg} / \mathrm{kg}$ were reported in samples from all eight reservoirs and included species found in all eight reservoirs. The highest percentages of samples that exceeded $0.30 \mathrm{mg} / \mathrm{kg}$ were from Monroe Lake (38 percent), Patoka Lake (33 percent), and C.M. Harden Lake (27 percent); the lowest percentage was from Brookville Lake ( 5 percent). Mercury concentrations in fish from Monroe Lake (median $0.21 \mathrm{mg} / \mathrm{kg}$ ) were statistically higher than those from J.E. Roush Lake, Brookville Lake, and Mississinewa Lake. Mercury concentrations in fish from C.M. Harden Lake (median $0.22 \mathrm{mg} / \mathrm{kg}$ ) were statistically higher than those from Mississinewa Lake (Kruskal-Wallis, $\mathrm{p}<0.001$; Tukey). The $\mathrm{Hg}$ concentrations in 76 percent of the 203 fish-tissue samples exceeded the $0.10-\mathrm{mg} / \mathrm{kg}$ reference benchmark for wildlife. The highest percentages of samples that exceeded $0.10 \mathrm{mg} / \mathrm{kg}$ were from Monroe Lake (92 percent), Salamonie Lake (90 percent), and C.M. Harden Lake (87 percent).

\section{Bioaccumulation}

A bioaccumulation factor (BAF) is the ratio of $\mathrm{MeHg}$ in fish tissue to dissolved $\mathrm{MeHg}$ in the water and offers a comparison of the food-web effects among the six reservoirs in Indiana with $\mathrm{MeHg}$ data. The BAFs indicate that $\mathrm{MeHg}$ concentrations in water became a million times higher in fish because of food-chain accumulation and magnification. BAFs were computed with measured concentrations of fish-tissue $\mathrm{MeHg}$ (as $\mathrm{Hg}$ ) data from all samples in the six reservoirs and the mean dissolved $\mathrm{MeHg}$ in water samples from the reservoirs. BAFs are presented as a range of values (table 10). 
Table 10. Methylmercury bioaccumulation factors for five reservoirs in Indiana.

[Hg, mercury; wet wt., wet weight; $\mathrm{mg} / \mathrm{kg}$, milligram per kilogram; $\mathrm{MeHg}$, methlylmercury; $\mathrm{ng} / \mathrm{L}$, nanogram per liter; BAF, bioaccumulation factor; $\mathrm{L} / \mathrm{kg}$, liter per kilogram; 106, one million]

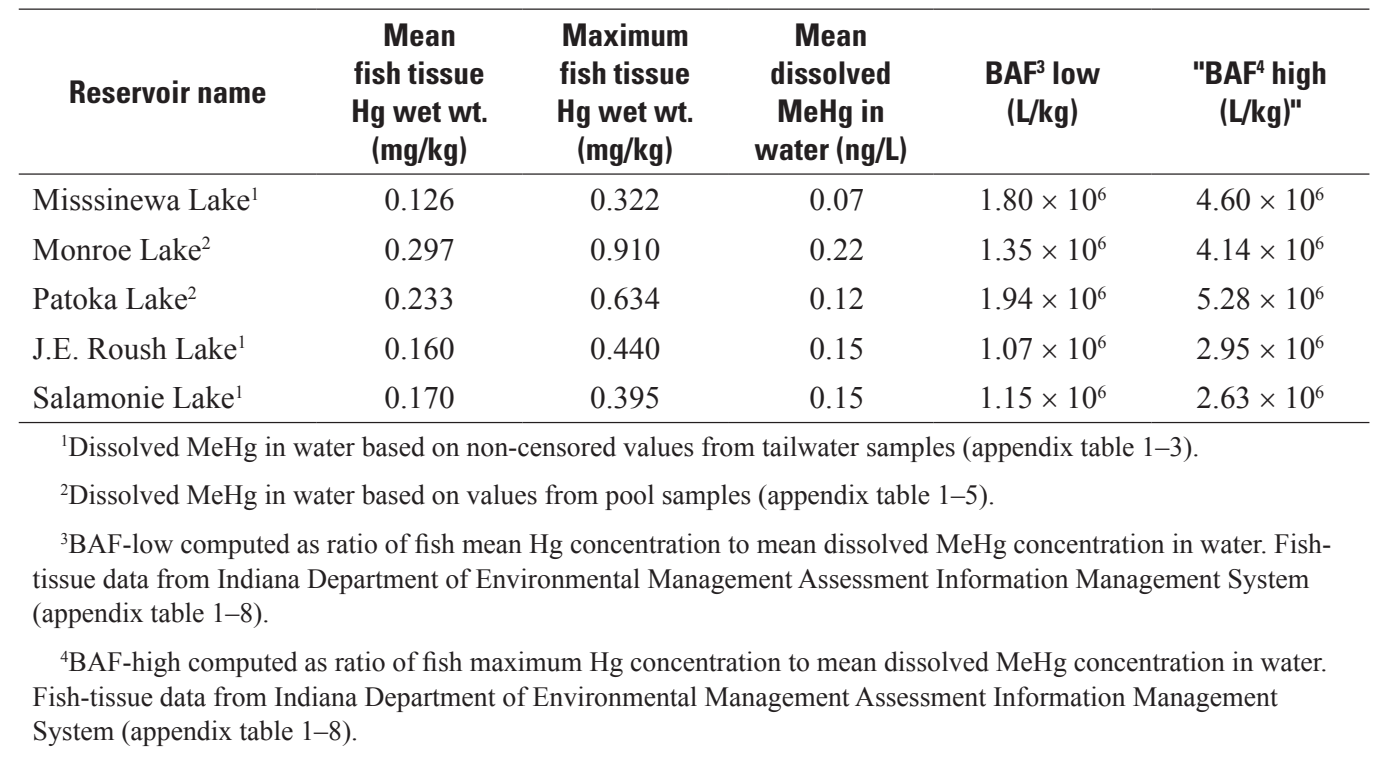

The low value in the range is the ratio of the mean fish tissue $\mathrm{MeHg}$ (as $\mathrm{Hg}$ ) to the mean dissolved $\mathrm{MeHg}$; this value includes $\mathrm{Hg}$ found in all species in a reservoir. The high value in the range is the ratio of the maximum fish tissue $\mathrm{MeHg}$ (as $\mathrm{Hg}$ ) to the mean dissolved $\mathrm{MeHg}$; this value includes the species at the top of the food web. BAFs for Monroe Lake and Patoka Lake were computed with reservoir-pool MeHg data. BAFs for J.E. Roush Lake, Mississinewa Lake, and Salamonie Lake were computed with reservoir-tailwater data because reservoir-pool water data were not available. Methylmercury was not detected in Brookville Lake pool or tailwater samples, and a BAF was not computed. All of the BAFs were a millionfold and differed by a factor of 5 or less. The highest BAFs were for Patoka Lake, ranging from $1.94 \times 10^{6}$ to $5.28 \times 10^{6}$ liters per kilogram.

\section{Implications for Fish Consumption}

Reservoir fish-tissue data indicated the highest levels of $\mathrm{Hg}$ and $\mathrm{MeHg}$ were observed in Monroe Lake and Patoka Lake, and these findings have implications for fish consumption by humans. Approximately 104,000 anglers were recorded to have caught fish in the pools and tailwaters of these two reservoirs in 2007 (Carnahan, 2008; Kittaka, 2008). Many fish that are caught are released, so it is important to distinguish which fish were "harvested" (for potential human consumption). The fish species that were reported as harvested, when compared with the available fish-tissue $\mathrm{Hg}$ concentrations data for each reservoir, indicate that most of the fish harvested are species likely to have fish-tissue $\mathrm{Hg}$ concentrations below the reference benchmark for human health. On the other hand, the fish species most frequently targeted and caught typically were not harvested but were likely to have $\mathrm{Hg}$ fish-tissue sample concentrations that exceed the reference benchmark for human health. These implications for fish consumption by humans are detailed in the following discussions.

Monroe Lake creel surveys (Kittaka, 2008) during the April through October 2007 fishing season, including 30 bass tournament days, recorded 38,019 anglers who caught 85,248 fish and harvested 51,053 (60 percent). Of the fish harvested, 88 percent were crappie (Pomoxis species), bluegill (Lepomis macrochirus), and channel catfish (Ictalurus punctatus). Fish-tissue samples of these species from Monroe Lake, 1996-2007, had Hg concentrations ranging from 0.166 to $0.320 \mathrm{mg} / \mathrm{kg}(n=58)$. These data indicate that most, but not all, fish of these three species harvested from Monroe Lake probably had $\mathrm{Hg}$ concentrations lower than the reference benchmark for human health.

Nearly half of the anglers at Monroe Lake targeted largemouth bass (Micropterus salmoides), striped bass (Morone species), and walleye (Sander vitreus). These three species accounted for 66 percent of the fish caught and 6.9 percent of the fish harvested. Comparing harvest to catch, 1.4 percent of largemouth bass, 27 percent of striped bass, and 66 percent of walleye were harvested. Mercury in fish-tissue samples from Monroe Lake, 1996-2007, had Hg concentrations ranging from 0.154 to $0.556 \mathrm{mg} / \mathrm{kg}$ in 11 largemouth bass samples and 0.175 to $0.910 \mathrm{mg} / \mathrm{kg}$ in 6 walleye samples. No data 
were available for fish tissue $\mathrm{Hg}$ in hybrid striped bass. The data indicated average-length largemouth bass and aboveaverage-length walleye harvested from Monroe Lake probably contained $\mathrm{Hg}$ concentrations that exceeded the reference benchmark for human health. ${ }^{11,12}$

Patoka Lake creel surveys (Carnahan, 2008) during the April through October 2007 fishing season, including 24 bass tournament days, recorded 65,860 anglers who caught 213,680 fish and harvested 117,007 (55 percent). Of the fish harvested, 97 percent were crappie, bluegill, and channel catfish. Fish-tissue samples of these species from Patoka Lake, 1996-2006, had Hg concentrations ranging from 0.023 to $0.221 \mathrm{mg} / \mathrm{kg}$. These data indicate that most fish of these species harvested from Patoka Lake probably did not contain $\mathrm{Hg}$ concentrations that exceeded the reference benchmark for human health.

Many anglers at Patoka Lake targeted largemouth bass and striped bass, and these two species accounted for 46 percent of the fish caught and 2.2 percent of the fish harvested. Comparing harvest to catch, 2 percent of largemouth bass and 42 percent of striped bass were harvested. Fish-tissue samples from Patoka Lake, 1996-2006, had Hg concentrations ranging from 0.304 to $0.634 \mathrm{mg} / \mathrm{kg}$ in largemouth bass. No data were available for fish tissue $\mathrm{Hg}$ in hybrid striped bass. These data indicate that the average-length largemouth bass harvested from Patoka Lake probably contained $\mathrm{Hg}$ concentrations that exceeded the reference benchmark for human health. ${ }^{13,14}$

\footnotetext{
${ }^{11}$ Largemouth bass harvested from Monroe Lake were 356 to 559 millimeters (mm) long, with a mean of $419 \mathrm{~mm}$. The largemouth bass samples from Monroe Lake exceeding $0.30 \mathrm{mg} / \mathrm{kg} \mathrm{Hg}$ were 296 to $480 \mathrm{~mm}$ long, with a mean of $361 \mathrm{~mm}$. Most of the largemouth bass harvested would be in the size range of samples exceeding $0.30 \mathrm{mg} / \mathrm{kg} \mathrm{Hg}$. Walleye harvested were 356 to $696 \mathrm{~mm}$ long, with a mean of $442 \mathrm{~mm}$. The walleye samples exceeding $0.30 \mathrm{mg} / \mathrm{kg} \mathrm{Hg}$ were 554 to $675 \mathrm{~mm}$ long, with a mean of $626 \mathrm{~mm}$. The above-average-size walleye, more than $554 \mathrm{~mm}$ long, would be in the size range of samples exceeding $0.30 \mathrm{mg} / \mathrm{kg} \mathrm{Hg}$.

${ }^{12}$ The advisory and guidelines applicable to Monroe Lake state that women of childbearing years, nursing mothers, and all children under age 15 may eat one meal per month of largemouth bass larger than 13 inches (in.) $(330 \mathrm{~mm})$ and walleye 19 to $21 \mathrm{in}$. ( 483 to $533 \mathrm{~mm}$ ) but should not eat walleye larger than 21 in. $(533 \mathrm{~mm})$.

${ }^{13}$ Largemouth bass harvested from Patoka Lake were a mean of $414 \mathrm{~mm}$ long. The largemouth bass samples from Patoka Lake exceeding $0.30 \mathrm{mg} / \mathrm{kg}$ $\mathrm{Hg}$ were 322 to $467 \mathrm{~mm}$ long, with a mean 371. The average-size largemouth bass, including those $414 \mathrm{~mm}$, would be in the size range of samples exceeding $0.30 \mathrm{mg} / \mathrm{kg} \mathrm{Hg}$.

${ }^{14}$ The advisory and guidelines applicable to Patoka Lake state that women of childbearing years, nursing mothers, and all children under age 15 may eat one meal per month of largemouth bass larger than 13 in. $(330 \mathrm{~mm})$.
}

\section{Limitations of Existing Information}

Existing information limits a uniform comparison of $\mathrm{Hg}$ and $\mathrm{MeHg}$ in the eight flood-control reservoirs in Indiana. Mercury and MeHg data from reservoir tailwaters and pools do not include the same reservoirs for the same seasons over the same time period. Tailwater $\mathrm{MeHg}$ data provide an insight into reservoir-pool conditions at J.E. Roush Lake, Mississinewa Lake, and Cagles Mill Lake, but reservoir-pool data, collected at least during summer thermal stratification, would provide a better comparison with the findings from the pools at Brookville Lake, Monroe Lake, and Patoka Lake. Multiyear, seasonal tailwater data are not available for Monroe Lake and Patoka Lake.

Mercury and $\mathrm{MeHg}$ data have not been collected from tailwaters and pools at C.M. Harden Lake and Salamonie Lake. These two reservoirs have percentages of agricultural land cover similar to J.E. Roush Lake and Mississinewa Lake (more than 70 percent), and all four reservoirs are in the Central Till Plains physiographic region. Mercury was detected in 100 percent and $\mathrm{MeHg}$ was detected in more than 70 percent of the tailwater samples from J.E. Roush Lake and Mississinewa Lake. These similarities indicate a potential for $\mathrm{Hg}$ and $\mathrm{MeHg}$ to be detected in tailwater samples from C.M Harden Lake and Salamonie Lake.

The duration and areal extent of conditions favoring $\mathrm{Hg}$ methylation are likely related to thermal stratification, but current knowledge for the reservoirs in Indiana is limited to a single summer sampling during thermal stratification. Other investigators have noted the important role of thermal destratification in the cycling and transport of $\mathrm{MeHg}$ in a reservoir system (for example, Alpers and others, 2008; Gray and Hines, 2009). In addition, autumn drawdown of water levels mixes and removes water from the pool, potentially changing $\mathrm{Hg}$ and $\mathrm{MeHg}$ transport within the reservoir and to downstream locations. Current knowledge does not include the distance downstream from a dam that $\mathrm{MeHg}$ from tailwaters persists, the annual reservoir yield of $\mathrm{MeHg}$ in tailwaters, and the $\mathrm{Hg}$ in fish from reaches downstream from reservoirs compared to fish in the reservoirs.

Finally, collection of water from reservoir pools and tailwaters for $\mathrm{Hg}$ and $\mathrm{MeHg}$ analysis throughout the year for several years - if coordinated with periodic collection of fish tissue samples for $\mathrm{Hg}$ analysis from these same locationswould provide a more thorough understanding of $\mathrm{Hg}$ delivery, methylation, food-web bioaccumulation, and downstream transport. 


\section{Summary and Conclusions}

Mercury $(\mathrm{Hg})$ is an element that occurs naturally, but evidence suggests that human activities have resulted in increased amounts being released to the atmosphere and land surface. When $\mathrm{Hg}$ is converted to toxic methylmercury ( $\mathrm{MeHg}$ ) in aquatic ecosystems, MeHg accumulates and increases in the food web so that some fish contain levels which pose a health risk to humans and wildlife that consume these fish.

Reservoirs, unlike natural lakes, are a part of river systems that are managed for flood control, which has unintentional effects on mercury transport and methylmercury formation. A condition known as the reservoir effect highlights the importance of $\mathrm{Hg}$ and $\mathrm{MeHg}$ in reservoirs. Previous investigations in North America have shown that lakes and reservoirs during summer thermal stratification can develop conditions in the hypolimnion that promote $\mathrm{MeHg}$ formation. In this study, two sets of data from six flood-control reservoirs in Indiana were compiled and interpreted to evaluate how $\mathrm{Hg}$ transport and $\mathrm{MeHg}$ formation in the water were affected by physical factors and chemical and biological conditions. The data included water samples collected and processed with ultraclean protocols and analyzed for $\mathrm{Hg}$ and $\mathrm{MeHg}$ by low-level methods, plus field determinations for water-quality characteristics and analysis of supplementary constituents.

One set of data was 66 seasonal samples from tailwaters downstream near the dams of four reservoirs-Brookville Lake, Cagles Mill Lake, J.E. Roush Lake, and Mississinewa Lake. In these samples, $\mathrm{Hg}$ ranged up to 15 nanograms per liter (ng/L), and the mean was $2.58 \mathrm{ng} / \mathrm{L}$. Methylmercury was detected only once in the tailwaters of Brookville Lake. The concentration ratios of $\mathrm{MeHg}$ to $\mathrm{Hg}$ ranged up to 64.8 percent, and the mean for the four reservoirs was 9.1 percent. Statistical analysis indicated the median concentration ratio of $\mathrm{MeHg}$ to $\mathrm{Hg}$ in summer tailwater samples, 6.7 percent, was significantly higher than in other seasons.

The other set of data was 53 samples from summer pools and tailwaters of three reservoirs: Brookville Lake, Monroe Lake, and Patoka Lake. Water-quality characteristics data from 1,440 depth-specific measurements in vertical profiles along 10 to 17 transects in each reservoir were used to select the depths for the water samples in the epilimnion, metalimnion, and hypolimnion thermal strata. Examination of changes in water temperature and dissolved oxygen with depth shows that the pool of each reservoir was thermally stratified at many of the transects.

Whole-water $\mathrm{Hg}$ (particulate plus dissolved $\mathrm{Hg}$ ) was reported in all samples from the three reservoir pools and concentrations ranged up to $5.51 \mathrm{ng} / \mathrm{L}$; the mean was $1.34 \mathrm{ng} / \mathrm{L}$. Mercury concentrations were highest in the hypolimnions of Monroe Lake and Patoka Lake. Water samples from Brookville Lake had considerably lower levels of whole-water $\mathrm{Hg}$, particulate $\mathrm{Hg}$, and $\mathrm{MeHg}$ than the other two reservoirs. Methylmercury was detected in 53 percent of the samples, including just a single sample from the Brookville Lake headwaters. Dissolved MeHg is the form that is most available for transfer to the aquatic food web. Concentration ratios of dissolved $\mathrm{MeHg}$ to $\mathrm{Hg}$ in the three reservoirs ranged up to 82 percent, and the median was 40 percent in Monroe Lake and 48 percent in Patoka Lake.

The hypolimnions of Monroe Lake and Patoka Lake were found to have zones with a high potential for conversion of $\mathrm{Hg}$ to $\mathrm{MeHg}$ - defined by water temperature less than 18.5 degrees Celsius and dissolved oxygen less than 3.5 milligrams per liter $(\mathrm{mg} / \mathrm{L})$, and water depths greater than 8 meters. These zones had the highest concentrations of $\mathrm{Hg}$ and $\mathrm{MeHg}$, the highest concentration ratios of dissolved $\mathrm{MeHg}$ to $\mathrm{Hg}$, and conditions favorable for sulfate reductions (water $\mathrm{pH}<7$, decreased dissolved sulfate concentrations, and observed hydrogen sulfide in water samples) compared to other strata. These zones extended through nearly half of the summer pools for these two reservoirs. Reservoir outflow came from this zone at Monroe Lake and contributed to a tailwater concentration ratio for dissolved $\mathrm{MeHg}$ to $\mathrm{Hg}$ of 56 percent. Reservoir outflow at Patoka Lake was not from this zone, and dissolved MeHg was not detected in the tailwater.

Factors affecting the transport of $\mathrm{Hg}$ to reservoirs favored Monroe Lake and Patoka Lake. These two reservoirs are in parts of Indiana with high Hg wet deposition so that the total wet plus dry atmospheric Hg-deposition rates at Monroe Lake and Patoka Lake were higher than at the other reservoirs. The drainage areas of these two reservoirs have the highest percentages of forest land cover supporting $\mathrm{Hg}$ dry deposition-82 percent for Monroe Lake and 67 percent for Patoka Lake. Furthermore, Monroe Lake and Patoka Lake are in landscapes with steep slopes and near-surface bedrock, which promote higher rates of precipitation runoff and potentially higher rates of $\mathrm{Hg}$ transport to streams and the reservoirs.

To depict food-web accumulation and magnification of $\mathrm{MeHg}$, fish-tissue $\mathrm{MeHg}$ (as $\mathrm{Hg}$ ) data for the reservoirs in Indiana were compiled from State records. Fish-tissue $\mathrm{Hg}$ concentrations from 203 samples ranged from 0.02 to 0.91 milligram per kilogram $(\mathrm{mg} / \mathrm{kg})$, and the median was $0.16 \mathrm{mg} / \mathrm{kg}$; 19 percent exceeded the reference benchmark for human health, $0.30 \mathrm{mg} / \mathrm{kg}$. Methylmercury (as $\mathrm{Hg}$ ) concentrations in fish differed among reservoirs, and the highest percentages of samples that exceeded the reference benchmark were from Monroe Lake (38 percent) and Patoka Lake (33 percent); the lowest was from Brookville Lake (5 percent). Concentrations in 76 percent of the 203 fish-tissue samples exceeded the $0.10-\mathrm{mg} / \mathrm{kg}$ reference benchmark for wildlife. The highest percentage of samples that exceeded $0.10 \mathrm{mg} / \mathrm{kg}$ were from Monroe Lake (92 percent), Salamonie Lake (90 percent), and C.M. Harden Lake (87 percent).

Because fishing is a popular activity at Monroe Lake and Patoka Lake, the fish species harvested and $\mathrm{Hg}$ fish-tissue data were compared. The implications for human consumption were that the highest numbers of fish harvested were crappie, bluegill, and catfish, which are more likely to have $\mathrm{MeHg}$ levels lower than the $0.30-\mathrm{mg} / \mathrm{kg}$ reference benchmark for human health. Largemouth bass were typically caught and released at these reservoirs, but 66 percent of walleye caught were harvested. The 
average-size largemouth bass harvested in both reservoirs and the above-average-size walleye harvested from Monroe Lake were likely to exceed the reference benchmark for human health.

Existing information limits a uniform comparison of $\mathrm{Hg}$ and $\mathrm{MeHg}$ in the eight flood-control reservoirs in Indiana. Mercury and $\mathrm{MeHg}$ data from tailwaters and pools at C.M. Harden Lake or Salamonie Lake have not been collected. Mercury and $\mathrm{MeHg}$ data from reservoir tailwaters and pools do not include the same reservoirs at the same intervals over the same time period. The duration and areal extent of conditions favoring $\mathrm{Hg}$ methylation are likely related to thermal stratification, but current knowledge is limited to a single time during thermal stratification. Currently unknown is the distance downstream that $\mathrm{MeHg}$ from tailwater outflow persists, the annual reservoir $\mathrm{MeHg}$ yields in tailwaters, or the associated fish $\mathrm{Hg}$ in downstream reaches.

In conclusion, this study has shown that $\mathrm{MeHg}$ is formed in six flood-control reservoirs in Indiana-Brookville Lake, Cagles Mill Lake, Mississinewa Lake, Monroe Lake, Patoka Lake, and J.E. Roush Lake. This MeHg accumulated and magnified to unsafe levels in the aquatic food web, including the food chains of fish caught in these lakes and consumed by anglers and wildlife. On the basis of information available, other reservoirs will have the highest rates of $\mathrm{Hg}$ transport and $\mathrm{MeHg}$ formation and the highest levels of $\mathrm{MeHg}$ in fish if they are located in forested landscapes with steep terrain and nearsurface bedrock, if they receive moderate to high atmospheric $\mathrm{Hg}$ wet and dry deposition, and if the water $\mathrm{pH}$ is less than 7 and dissolved oxygen is less than $3.5 \mathrm{mg} / \mathrm{L}$ to promote sulfate reduction. These conditions will be most prevalent during thermal stratification in the summer, leading to the potential for MeHg to be released in tailwater-especially if the water that is released is from the hypolimnion or metalimnion. Additional multiseason studies of $\mathrm{Hg}$ and $\mathrm{MeHg}$ in water and fish from reservoir pools and tailwaters in Indiana and other states could provide the data needed to evaluate risks to humans and wildlife and to assess reservoir management options to mitigate these risks.

\section{References}

Alpers, C.N., Stewart, A.R., Saiki, M.K., Marvin-DiPasquale, M.C., Topping, B.R., Rider, K.M., Gallanthine, S.K., Kester, C.A., Rye, R.O., Antweiler, R.C., and De Wild, J.F., 2008, Environmental factors affecting mercury in Camp Far West Reservoir, California, 2001-03: U.S. Geological Survey Scientific Investigations Report 2006-5008, 358 p.

Arar, E.J., and Collins, G.B., 1997, In vitro determination of chlorophyll $a$ and phaeophytin $a$ in marine and freshwater algae by fluorescence (rev. 1.2): Cincinnati, Ohio, U.S. Environmental Protection Agency, National Exposure Research Laboratory, Office of Research and Development, Method 445.0-1, 22 p., accessed June 2011 at http://www. epa.gov/nerlcwww/m445_0.pdf.
Becker, D.S., and Bigham, G.N., 1995, Distribution of mercury in the aquatic food web of Onondaga Lake, New York: Water, Air, and Soil Pollution, v. 80, p. 563-571.

Bell, A.H., and Scudder, B.C., 2007, Mercury accumulation in periphyton of eight river ecosystems: Journal of the American Water Resources Association, v. 43, no. 4, p. 957-968.

Bird, S.M., Fram, M.S., and Crepeau, K.L., 2003, Method of analysis by the U.S. Geological Survey California District Sacramento Laboratory-Determination of dissolved organic carbon in water by high temperature catalytic oxidation, method validation, and quality-control practices: U.S. Geological Survey Open-File Report 03-366, 14 p.

Bloom, N.S., 1992, On the chemical form of mercury in edible fish and marine invertebrate tissue: Canadian Journal of Fisheries and Aquatic Science, v. 49, p. 1010-1017.

Bodaly, R.A.; Beaty, K.G.; Hendzel, L.H.; Majewski, A.R.; Paterson, M.J.; Rolfhus, K.R.; Penn, A.F.; St. Louis, V.L.; Hall, B.D.; Matthews, C.J.D.; Cherewyk, K.A.; Mailman, Mariah; Hurley, J.P.; Schiff, S.L.; and Venkiteswaran, J.J., 2004, Experimenting with hydroelectric reservoirs: Environmental Science \& Technology, v. 38, no. 18, p. $346 \mathrm{~A}-352 \mathrm{~A}$.

Bodaly, R.A., Jansen, W.A., Majewski, A.R., Fudge, R.J.P., Strange, N.E., Derksen, A.J., and Green, D.J., 2007, Postimpoundment time course of increased mercury concentrations in fish in hydroelectric reservoirs of northern Manitoba, Canada: Archive of Environmental Contamination and Toxicology, v. 53, no. 3, p. 379-389.

Brigham, M.E., Wentz, D.A., Aiken, G.R., and Krabbenhoft, D.P., 2009, Mercury cycling in stream ecosystems. 1. Water column chemistry and transport: Environmental Science \& Technology, v. 43, no. 8, p. 2720-2725.

Brumbaugh, W.G., Krabbenhoft, D.P., Helsel, D.R., Wiener, J.G., and Echols, K.R., 2001, A national pilot study of mercury contamination of aquatic ecosystems along multiple gradients - Bioaccumulation in fish: U.S. Geological Survey Biological Science Report 2001-009, 28 p.

Canavan, C.M., Caldwell, C.A., and Bloom, N.S. 2000, Discharge of methylmercury-enriched hypolimnetic water from a stratified reservoir: Science of the Total Environment, v. 260, p. 159-170.

Carnahan, D.P., 2008, Patoka Lake fish management report: Indiana Department of Natural Resources Division of Fish and Wildlife, $45 \mathrm{p}$.

Chasar, L.C., Scudder, B.C., Stewart, A.R., Bell, A.H., and Aiken, G.R., 2009, Mercury cycling in stream ecosystems. 3. Tophic dynamics and methylmercury accumulation: Environmental Science \& Technology, v. 43, no. 8, p. 2733-2739. 
Cocca, Paul, 2001, Mercury maps-A quantitative spatial link between air deposition and fish tissue: U.S. Environmental Protection Agency, Office of Water, EPA-823-R-01-009, $31 \mathrm{p}$.

DeWild, J.F., Olson, M.L., and Olund, S.D., 2002, Determination of methyl mercury by aqueous phase ethylation, followed by gas chromatographic separation with cold vapor atomic fluorescence detection: U.S. Geological Survey Open-File Report 01-445, 19 p.

DeWild, J.F., Olund, S.D., Olson, M.L., and Tate, M.T., 2004, Methods for the preparation and analysis of solids and suspended solids for methylmercury: U.S. Geological Survey Techniques and Methods, book 5, chap. A7, 13 p.

Drenner, R.W., Chumchal, M.M., Wente, S.P., McGuire, M., and Drenner, S.M., 2011, Landscape-level patterns of mercury contamination of fish in North Texas, USA: Environmental Toxicology and Chemistry, v. 30, no. 9, p. 2041-2045

Driscoll, C.T., Mason, R.P., Chan, H.M., Jacob, D.J., and Pirrone, Nicola, 2013, Mercury as a global pollutant-Sources, pathways, and effects: Environmental Science \& Technology, v. 47, p. 4967-4983

Environmental Systems Research Institute, 2006, ArcGIS version 9.2.

Evers, D.C., 2005, Mercury connections-The extent and effects of mercury pollution in northeastern North America: Gorham, Maine, Biodiversity Research Institute, 29 p.

Fishman, M.J., and Friedman, L.C., 1989, Methods for determination of inorganic substances in water and fluvial sediments: U.S. Geological Survey Techniques of WaterResources Investigations, book 5, chap. A1, 545 p.

Gray, H. H., 1989, Quaternary geologic map of Indiana: Indiana Geological Survey Miscellaneous Map 49.

Gray, H.H., 2000, Physiographic divisions of Indiana: Indiana Geological Survey Special Report 61, 15 p., 1 pl.

Gray, J.E., and Hines, M.E., 2009, Biogeochemical mercury methylation influenced by reservoir eutrophication, Salmon Falls Creek Reservoir, Idaho, USA: Chemical Geology, v. 258, p. 157-167.

Grieb, T.M., Driscoll, C.T., Gloss, S.P., Schofield, C.L., Bowie, G.L., and Porcella, D.B., 1990, Factors affecting mercury accumulation in fish in the Upper Michigan Peninsula: Environmental Toxicology and Chemistry, v. 9, p. 919-930.

Grigal, D.F., 2002, Inputs and outputs of mercury from terrestrial watesheds-A review: National Research Council of Canada Environmental Reviews, v. 10, no. 1, p. 1-39.
Guy, H.P., 1969, Laboratory theory and methods for sediment analysis: U.S. Geological Survey Techniques of WaterResources Investigations, book 5, chap. C1, 58 p.

Hall, B.D., St. Louis, V.L., Rolfhus, K.R., Bodaly, R.A., Beaty, K.G., Paterson, M.J., and Peech Cherewyk, K.A., 2005, Impacts of reservoir creation on the biogeochemical cycling of methyl mercury and total mercury in boreal upland forests: Ecosystems, v. 8, no 3, p. 248-266.

Hammerschmidt, C.R., Wiener, J.G., Frazier, B.E., and Rada, R.G., 1999, Methylmercury content of eggs in yellow perch related to maternal exposure in four Wisconsin lakes: Environmental Science \& Technology, v. 33, p. 999-1003.

Hartman, J.S., Weisberg, P.J., Pillai, R., Ericksen, J.A., Kuiken, T., Lindberg, S.E., Zhang, H., Rytuba, J.J., and Gustin, M.S., 2009, Application of a rule-based model to estimate mercury exchange for three background biomes in the continental United States: Environmental Science \& Technology, v. 43, p. 4989-4994.

Harris, R.C., Krabbenhoft, D.P., Mason, R.P., Murray, M.W., Reash, R., and Saltman, T., eds., 2007, Ecosystem responses to mercury contamination-Indicators of change: Pensacola, Fla., Society of Environmental Toxicology and Chemistry Press, 216 p.

Harris, R.C.; Rudd, J.W.M.; Amyot, Marc; Babiarz, C.L.; Beaty, K.G.; Blanchfield, P.J.; Bodaly, R.A.; Branfireun, B.A.; Gilmour, C.C.; Graydon, J.A.; Heyes, Andrew; Hintelmann, Holger; Hurley, J.P.; Kelly, C.A.; Krabbenhoft, D.P.; Lindberg, S.E.; Mason, R.P.; Paterson, M.J.; Podemski, C.L.; Robinson, Art; Sandilands, K.A.; Southworth, G.R.; St. Louis, V.L.; and Tate M.T., 2007, Whole-ecosystem study shows rapid fish-mercury response to changes in mercury deposition: Proceedings of the National Academy of Sciences, v. 104, no. 42, p. 16586-16591.

Helsel, D.R., and Hirsch, R.M., 1995, Statistical methods in water resources (2d printing): Amsterdam, Elsevier Science Publishers, 529 p.

Homer, C., Huang, C. ,Yang, L., Wylie, B., and Coan, M., 2004, Development of a 2001 National Land Cover Database for the United States: Photogrammetric Engineering and Remote Sensing, v. 70, no. 7, p. 829-840.

Homoya, M.A., Abrell, D.B., Aldrich, J.R., and Post, T.W., 1985. The natural regions of Indiana: Proceedings of the Indiana Academy of Science, v. 94, p. 245-268.

Horowitz, A.J., Demas, C.R., Fitzgerald, K.K., Miller, T.L., and Rickert, D.A., 1994, U.S. Geological Survey protocol for the collection and processing of surface-water samples for the subsequent determination of inorganic constituents: U.S. Geological Survey Open-File Report 94-539, 57 p.

Indiana Geological Survey, 2011, Indiana map: accessed August 2011 at http://maps.indiana.edu/ 
Kelly, C.A., Rudd, J.W.M., Bodaly, R.A., Roulet, N.P., St. Louis, V.L., Heyes, A., Moore, T.R., Schiff, S., Aravena, R., Scott, K.J., Dyck, B., Harris, R., Warner, B., and Edwards, G., 1997, Increases in fluxes of greenhouse gases and methyl mercury following flooding of an experimental reservoir: Environmental Science \& Technology, v. 31, no. 5, p. 1334-1344.

Kittaka, D.S., 2008, Fishing pressure and fish harvest at Monroe Reservoir, 2007: Indiana Department of Natural Resources Division of Fish and Wildlife, $16 \mathrm{p}$.

Klaper, R., Rees, C.B., Drevnick, P., Weber, D., Sandheinrich, M., and Carvan, M.J., 2006, Gene expression changes related to endocrine function and decline in reproduction in fathead minnow (Pimephales promelas) after dietary methylmercury exposure: Environmental Health Perspectives, v. 114 , no. 9 , p. 1337-1343.

Kolka, R.K., Nater, E.A., Grigal, D.F., and Verry, E.S., 1999, Atmospheric inputs of mercury and organic carbon into a forested upland/bog watershed: Water, Air, and Soil Pollution, v. 113, p. 273-294.

Lindberg, S., Bullock, R., Ebinghaus, R., Engstrom, D., Feng, X., Fitzgerald, W., Pirrone, N., Prestbo, E., and Seigneur, C., 2007, A synthesis of progress and uncertainties in attributing the sources of mercury in deposition: Ambio, v. 36, no. 1, p. 19-32.

Mailman, M., Stepnuk, L., Cicek, N., and Bodaly, R.A., 2006, Strategies to lower methyl mercury concentrations in hydroelectric reservoirs and lakes - A review: Science of the Total Environment, v. 368, p. 224-235.

Mast, M.A., and Krabbenhoft, D.P., 2010, Comparison of mercury in water, bottom sediment, and zooplankton in two Front Range reservoirs in Colorado, 2008-09: U.S. Geological Survey Scientific Investigations Report 2010-5037, $20 \mathrm{p}$.

Mergler, D., Anderson, H.A., Chan, L.H.M., Mahaffey, K.R., Murray, M., Sakamoto, M., and Stern., A.H., 2007, Methylmercury exposure and health effects in humans-A worldwide concern: Ambio, v. 36, no. 1, p. 3-11.

Morel, F.M.M., Kraepiel, A.M.L., and Amyot, Marc, 1998, The chemical cycle and bioaccumulation of mercury: Annual Review of Ecology and Systematics, v. 29, p. 543-566.

Munthe, John; Bodaly, R.A.; Branfireun, B.A.; Driscoll, C.T.; Gilmour, C.C.; Harris, Reed; Horvat, Milena; Lucotte, Marc; and Malm, Olaf, 2007, Recovery of mercury-contaminated fisheries: Ambio, v. 36, no. 1, p. 33-44.

National Research Council, 2000, Toxicological effects of methylmercury: Washington, D.C., National Academy Press, 344 p.
Negry, J., Melwani, A., Stephenson, M., and Davis, J., 2011, Mercury in California lakes and reservoirs-Factors influencing bioaccumulation, in 10th International Conference on Mercury as a Global Pollutant, Halifax, Nova Scotia, Canada, July 24-29, 2011: Proceedings, p.227.

Olson, M.L., and De Wild, J.F., 1997, Determination of total mercury in water by oxidation, purge and trap, and cold vapor atomic fluorescence spectrometry: U.S. Geological Survey National Mercury Laboratory Standard Operating Procedure SOP001, accessed June 2011 at http://wi.water. usgs.gov/mercury-lab/forms/hg_tsop001_rev_4.pdf.

Olund, S.D., DeWild, J.F., Olson, M.L., and Tate, M.T., 2004, Methods for the preparation and analysis of solids and suspended solids for total mercury: U.S. Geological Survey Techniques and Methods, book 5, chap. A8, $15 \mathrm{p}$.

Patton, C.J.; Kammer, James; and Brenton, Ronald, 2000, New particulate carbon and nitrogen methods at the NWQL: U.S. Geological Survey, National Water Quality Laboratory, 25 p., accessed June 2011 at http://wwwnwql.cr.usgs.gov/ htmls/pen.ppt.

Plourde, Yanick; Lucotte, Marc; and Pichet, Pierre, 1997, Contribution of suspended particulate matter and zooplankton to MeHg contamination of the food chain in midnorthern Quebec (Canada) reservoirs: Canadian Journal of Fisheries and Aquatic Sciences, v. 54, no. 4, p. 821-831.

Risch, M.R., Baker, N.T., Fowler, K.K, Egler, A.L., and Lampe, D.C., 2010, Mercury in Indiana watersheds-Retrospective for 2001-2006: U.S. Geological Survey Professional Paper 1780, 66 p. with appendixes.

Risch, M.R., DeWild, J.F., Krabbenhoft, D.P., Kolka, R.K., and Zhang, L., 2012, Litterfall mercury dry deposition in the eastern USA: Environmental Pollution, v. 161, p. 284-290, http://dx.doi.org/10.1016/j.envpol.2011.06.005.

Sandheinrich, M.B., and Wiener, J.G., 2011, Methylmercury in freshwater fish-Recent advances in assessing toxicity of environmentally relevant exposures, in Beyer, W.N., and Meador J.P., eds., Environmental contaminants in biotaInterpreting tissue concentrations ( $2 \mathrm{~d}$ ed.): Boca Raton, Fla., CRC Press, p. 169-190.

Scheuhammer, A.M., Meyer, M.W., Sandheinrich, M.B., and Murray, M.W., 2007, Effects of environmental methylmercury on the health of wild birds, mammals, and fish: Ambio, v. 36 , no. 1 , p. $12-18$.

Scudder, B.C., Chasar, L.C., Wentz, D.A., Bauch, N.J., Brigham, M.E., Moran, P.W., and Krabbenhoft, D.P., 2009, Mercury in fish, bed sediment, and water from streams across the United States, 1998-2005: U.S. Geological Survey Scientific Investigations Report 2009-5109, 74 p. 
St. Louis, V.L.; Rudd, J.W.M.; Kelly, C.A.; Bodaly, R.A.; Paterson, M.J.; Beaty, K.G.; Hesslein, R.H.; Heyes, Andrew; and Majewski, A.R., 2004, The rise and fall of mercury methylation in an experimental reservoir: Environmental Science \& Technology, v. 38, no. 5, p. 1348-1358.

Stahl, L.L., Snyder, B.D., Olsen, A.R., and Pitt, J.L., 2009, Contaminants in fish tissue from U.S. lakes and reservoirsA national probabilistic study: Environmental Monitoring and Assessment, v. 150, p. 3-19.

Stewart, A.R., Saiki, M.K., Kuwabara, J.S., Alpers, C.N., Marvin-DiPasquale, M., and Krabbenhoft, D.P., 2008, Influence of plankton mercury dynamics and trophic pathways on mercury concentrations of top predator fish of a miningimpacted reservoir: Canadian Journal of Fisheries and Aquatic Sciences, v. 65, p. 2351-2366.

Ulberg, A.L., and Risch, M.R., 2008, Total mercury and methylmercury in Indiana streams: U.S. Geological Survey Scientific Investigations Report 2008-5176, 76 p.

U.S. Army Corps of Engineers, 2014, U.S. Army Corps of Engineers, Louisville District facts about the lakes: accessed June 2014 http://www.lrl.usace.army.mil/Missions/ CivilWorks/WaterInformation/LakeInformation/Factsaboutthelakes.aspx.

U.S. Environmental Protection Agency, 1996, Method 1669Sampling ambient water for trace metals at EPA water quality criteria levels: Office of Water, EPA 821-R-96-008, $36 \mathrm{p}$.

U.S. Environmental Protection Agency, 1997, Mercury study report to Congress, Volume VII-Characterization of human health and wildlife risks from mercury exposure in the United States: Office of Air Quality Planning and Standards and Office of Research and Development, EPA-452/R-97-009, $152 \mathrm{p}$.

U.S. Environmental Protection Agency, 1999, The national survey of mercury concentrations in fish-Data base summary, 1990-1995: Office of Water, EPA-823-R-99-014 [variously paginated].

U.S. Environmental Protection Agency, 2001a, Water quality criterion for the protection of human health-Methylmercury: Office of Water, EPA-823-R-01-001, accessed March 2010 at http://water.epa.gov/scitech/swguidance/ standards/criteria/health/upload/2009_01_15_criteria_methylmercury_mercury-criterion.pdf.

U.S. Environmental Protection Agency, 2001b, Guidance for implementation and use of EPA Method 1631 for the determination of low-level mercury (40 CFR pt. 136): Office of Water, EPA 821-R-01-023, 78 p.
U.S. Environmental Protection Agency, 2001c, Draft Method 1630 , Methyl mercury in water by distillation, aqueous ethylation, purge and trap, and CVAFS: Washington, D.C., U.S. Environmental Protection Agency, EPA-821-R-01-020 [variously paginated].

U.S. Environmental Protection Agency, 2002, Method 1631, Revision E-Mercury in water by oxidation, purge and trap, and cold vapor atomic fluorescence spectrometry: Office of Water, EPA-821-R-99-005, 40 p.

U.S. Environmental Protection Agency, 2009, National lakes assessment-A collaborative survey of the nation's lakes: Washington, D.C., Office of Water and Office of Research and Development, EPA 841-R-09-001, 118 p.

U.S. Environmental Protection Agency, 2010, Guidance for implementing the January 2001 methylmercury water quality criterion: Office of Science and Technology, EPA-823-R-09-002, accessed August 2011 at http:// water.epa.gov/scitech/swguidance/standards/criteria/health/ upload/mercury2010.pdf.

U.S. Geological Survey, variously dated, National field manual for the collection of water-quality data: U.S. Geological Survey Techniques of Water-Resources Investigations, book 9, chaps. A1-A9, available online at http://pubs.water.usgs. gov/twri9A.

U.S. Geological Survey, 2007, Quality assurance plan for U.S. Geological Survey Mercury Research Laboratory: Webbased manual, accessed August 2010 at http://wi.water.usgs. gov/mercury-lab/quality-assurance-manual.html.

U.S. Geological Survey, 2011, StreamStats: Interactive map/ database, accessed June 2011 at http://water.usgs.gov/osw/ streamstats/indiana.html.

Yeardley, R.B., Jr., Lazorchak, J.M., and Paulsen, S.G., 1998, Elemental fish tissue contamination in northeastern U.S. lakes-Evaluation of an approach to regional assessment: Environmental Toxicology and Chemistry, v. 17, no. 9, p. $1875-1884$.

Zhang, L., Wright, L.P., and Blanchard, P., 2009, A review of current knowledge concerning dry deposition of atmospheric mercury: Atmospheric Environment, v. 43, p. $5853-5864$.

Zhang, L., Blanchard, P., Gay, D.A., Prestbo, E.M., Risch, M.R., Johnson, D., Narayan, J., Zsolway, R., Holsen, T.M., Miller, E.K., Castro, M.S., Graydon, J.A., St. Louis, V.L., and Dalziel, J., 2012, Estimation of speciated and total mercury dry deposition at monitoring locations in eastern and central North America: Atmospheric Chemistry and Physics, v. 12, p. 4327-4340. 


\section{Appendix 1. Supplemental Data}

Table 1-1. Reservoir-pool and tailwater mercury quality-control field blank sample data .........42

Table 1-2. Quality-control data for reservoir-pool and tailwater mercury field duplicate samples....................................................................................................

Table 1-3. Reservoir-tailwater mercury data...........................................................................

Table 1-4. Hydrologic conditions at three Indiana reservoirs ....................................................4

Table 1-5. Reservoir-pool and tailwater data for mercury, water-quality characteristics, and supplementary constituents .......................................................46

Table 1-6. Percentages of land-cover categories in reservoir drainage areas..........................50

Table 1-7. Mercury wet- and dry-deposition rates and loads to reservoir watersheds in Indiana ......................................................................................5

Table 1-8. Reservoir fish-tissue sample and mercury data ..............................................................51 
Table 1-1. Reservoir-pool and tailwater mercury quality-control field blank sample data.

[QC, quality control; Hg, mercury; ng/L, nanogram per liter; MeHg, methylmercury; n.a., not analyzed for; <, less than]

\begin{tabular}{|c|c|c|c|c|c|c|c|c|}
\hline $\begin{array}{l}\text { Field } \\
\text { ID }\end{array}$ & Type of QC sample & USGS station ID & $\begin{array}{c}\text { Sample date } \\
\text { (month/day/ } \\
\text { year) }\end{array}$ & $\begin{array}{c}\text { Particulate } \\
\mathrm{Hg} \text { (ng/L) }\end{array}$ & $\begin{array}{l}\text { Dissolved } \\
\mathrm{Hg}(\mathrm{ng} / \mathrm{L})^{1}\end{array}$ & $\begin{array}{c}\text { Particulate } \\
\text { MeHg } \\
\text { (ng/L) }\end{array}$ & $\begin{array}{c}\text { Dissolved } \\
\text { MeHg } \\
\text { (ng/L) }\end{array}$ & $\begin{array}{l}\text { Unfiltered } \\
\mathrm{Hg}(\mathrm{ng} / \mathrm{L})^{1}\end{array}$ \\
\hline FB1 & Field equipment/filter blank & 390034086304801 & $7 / 6 / 2009$ & $<0.07$ & 0.06 & $<0.01$ & $<0.04$ & n.a. \\
\hline FB2 & Field equipment/filter blank & 392628084595901 & $7 / 13 / 2009$ & $<0.10$ & 0.18 & $<0.02$ & $<0.04$ & n.a. \\
\hline FB3 & Field equipment/filter blank & 382553086420601 & $7 / 20 / 2009$ & $<0.10$ & 0.06 & $<0.02$ & $<0.04$ & n.a. \\
\hline BB1 & Blank source water/bottle blank & 390034086304801 & $7 / 6 / 2009$ & n.a. & n.a. & n.a. & n.a. & 0.17 \\
\hline BB2 & Blank source water/bottle blank & 392628084595901 & $7 / 13 / 2009$ & n.a. & n.a. & n.a. & n.a. & 0.48 \\
\hline BB3 & Blank source water/bottle blank & 382553086420601 & $7 / 20 / 2009$ & n.a. & n.a. & n.a. & n.a. & 0.17 \\
\hline
\end{tabular}

'Average unfiltered $\mathrm{Hg}$ concentration in three blank source-water samples $(0.27 \mathrm{ng} / \mathrm{L})$ exceeded average dissolved $\mathrm{Hg}$ concentration in field equipment/ filter blanks $(0.10 \mathrm{ng} / \mathrm{L})$. Unfiltered $\mathrm{Hg}$ concentration in blank source water exceeded dissolved $\mathrm{Hg}$ concentration in field equipment/filter blank for each date.

Table 1-2. Quality-control data for reservoir-pool and tailwater mercury field duplicate samples.

[QC, quality control; Hg, mercury; ng/L, nanogram per liter; MeHg, methylmercury; n.a., not analyzed for; RPD, relative percent difference; <, less than; ND., no relative percent difference computed for two $<$ values]

\begin{tabular}{|c|c|c|c|c|c|c|c|c|c|c|c|c|c|c|}
\hline \multirow[b]{2}{*}{ Field ID } & \multirow[b]{2}{*}{ USGS station ID } & \multirow{2}{*}{$\begin{array}{c}\text { Sample } \\
\text { date } \\
\text { (month/ } \\
\text { day/ year) }\end{array}$} & \multicolumn{3}{|c|}{ Particulate $\mathrm{Hg}$ (ng/L) } & \multicolumn{3}{|c|}{ Dissolved $\mathrm{Hg}$ (ng/L) } & \multicolumn{3}{|c|}{ Particulate $\mathrm{MeHg}$ (ng/L) } & \multicolumn{3}{|c|}{ Dissolved MeHg (ng/L) } \\
\hline & & & Sample & Duplicate & $\begin{array}{c}\text { RPD } \\
\text { (percent) }^{1}\end{array}$ & Sample & Duplicate & $\begin{array}{c}\text { RPD } \\
\text { (percent) }^{1}\end{array}$ & Sample & Duplicate & $\begin{array}{c}\text { RPD } \\
\text { (percent) }^{1}\end{array}$ & Sample & Duplicate & $\begin{array}{c}\text { RPD } \\
\text { (percent) }\end{array}$ \\
\hline Monroe 5A-R & 390359086263501 & $7 / 8 / 2009$ & 0.23 & 0.23 & 0.9 & 0.52 & 0.33 & 44.7 & 0.06 & $<0.02$ & 100.0 & $<0.04$ & $<0.04$ & ND \\
\hline Monroe 5B-R & 390359086263501 & $7 / 8 / 2009$ & 2.23 & 2.43 & 8.7 & 1.26 & 1.18 & 6.6 & 0.55 & 0.56 & 2.3 & 0.73 & 0.64 & 13.1 \\
\hline Monroe 6-R & 390229086280401 & $7 / 8 / 2009$ & 0.25 & 0.23 & 8.3 & 0.47 & 0.33 & 35.0 & $<0.03$ & $<0.03$ & ND & $<0.04$ & $<0.04$ & ND \\
\hline Brookville 3A-R & 392721084585901 & $7 / 14 / 2009$ & 0.16 & 0.15 & 7.8 & 0.36 & 0.26 & 32.3 & $<0.03$ & $<0.02$ & ND & $<0.04$ & $<0.04$ & ND \\
\hline Brookville 3B-R & 392721084585901 & $7 / 14 / 2009$ & 0.12 & 0.12 & 1.7 & 0.40 & 0.32 & 22.2 & $<0.03$ & $<0.03$ & ND & $<0.04$ & $<0.04$ & ND \\
\hline Brookville 3C-R & 392721084585901 & $7 / 14 / 2009$ & 0.23 & 0.21 & 8.1 & 0.35 & 0.32 & 9.0 & $<0.03$ & $<0.03$ & ND & $<0.04$ & $<0.04$ & ND \\
\hline Patoka 2A-R & 382553086420601 & $7 / 20 / 2009$ & 0.18 & 0.18 & 2.8 & 0.53 & 0.28 & 61.7 & $<0.03$ & $<0.03$ & ND & $<0.04$ & $<0.04$ & ND \\
\hline Patoka 2B-R & 382553086420601 & $7 / 20 / 2009$ & 0.40 & 0.42 & 3.7 & 0.26 & 0.66 & 87.0 & 0.06 & 0.06 & 0 & $<0.04$ & $<0.04$ & ND \\
\hline Patoka 2C-R & 382553086420601 & $7 / 20 / 2009$ & 1.10 & 1.02 & 7.3 & 0.49 & 0.44 & 10.8 & 0.33 & 0.29 & 13.2 & 0.28 & 0.34 & 19.4 \\
\hline
\end{tabular}

${ }^{1}$ Relative percent difference is the nonnegative difference of the paired duplicate sample concentrations divided by the average of the concentrations, expressed as a percentage. For one pair of duplicate samples with a 0.06 concentration and $\mathrm{a}<0.02$ value, the $<0.02$ value was set to 0.019 for calculating the RPD of 100 . 
Table 1-3. Reservoir-tailwater mercury data.

[Hg, unfiltered mercury; ng/L, nanogram per liter; PHg, particulate mercury; MeHg, unfiltered methylmercury; <, less than reporting limit listed; n.d., not determined because $\mathrm{PHg}$ or $\mathrm{MeHg}$ was not reported]

\begin{tabular}{|c|c|c|c|c|c|c|c|}
\hline Reservoir & $\begin{array}{c}\text { Sample date } \\
\text { (month/day/ } \\
\text { year) }\end{array}$ & Season & $\underset{(\mathbf{n g} / \mathrm{L})^{1}}{\mathrm{Hg}}$ & $\underset{(\mathrm{ng} / \mathrm{L})^{1}}{\mathrm{PHg}}$ & $\begin{array}{c}\mathrm{MeHg} \\
(\mathrm{ng} / \mathrm{L})^{1}\end{array}$ & $\begin{array}{l}\text { Ratio of } \\
\text { PHg to } \mathrm{Hg}^{2} \\
\text { (percent) }\end{array}$ & $\begin{array}{c}\text { Ratio of } \\
\text { MeHg to } \mathrm{Hg} \\
\text { (percent) }^{3}\end{array}$ \\
\hline \multirow[t]{17}{*}{ Brookville Lake } & $3 / 11 / 2002$ & Winter & 0.31 & 0.31 & $<0.3$ & 100 & n.d. \\
\hline & $6 / 10 / 2002$ & Spring & 0.61 & 0.33 & $<0.3$ & 54 & n.d. \\
\hline & 9/9/2002 & Summer & 0.32 & 0.10 & $<0.3$ & 31 & n.d. \\
\hline & $12 / 16 / 2002$ & Fall & 0.19 & 0.19 & $<0.3$ & 100 & n.d. \\
\hline & $4 / 21 / 2003$ & Spring & 0.81 & 0.24 & $<0.3$ & 30 & n.d. \\
\hline & $7 / 21 / 2003$ & Summer & $<0.3$ & $<0.3$ & $<0.3$ & n.d. & n.d. \\
\hline & $10 / 20 / 2003$ & Fall & 0.55 & 0.33 & $<0.3$ & 60 & n.d. \\
\hline & $1 / 12 / 2004$ & Winter & 1.02 & 0.78 & $<0.3$ & 76 & n.d. \\
\hline & 9/3/2004 & Summer & 0.54 & 0.14 & $<0.04$ & 26 & n.d. \\
\hline & $10 / 22 / 2004$ & Fall & 1.02 & 0.61 & $<0.04$ & 60 & n.d. \\
\hline & $2 / 25 / 2005$ & Winter & 1.85 & 0.64 & $<0.04$ & 35 & n.d. \\
\hline & $6 / 30 / 2005$ & Spring & 0.34 & 0.11 & $<0.04$ & 32 & n.d. \\
\hline & $9 / 16 / 2005$ & Summer & 0.32 & 0.10 & $<0.04$ & 31 & n.d. \\
\hline & $12 / 19 / 2005$ & Fall & 0.24 & 0.07 & $<0.04$ & 29 & n.d. \\
\hline & $3 / 17 / 2006$ & Winter & 1.21 & 0.56 & $<0.04$ & 46 & n.d. \\
\hline & $5 / 18 / 2006$ & Spring & 0.64 & 0.20 & $<0.04$ & 31 & n.d. \\
\hline & 9/8/2006 & Summer & 0.26 & 0.04 & 0.04 & 15 & 15.4 \\
\hline \multirow[t]{18}{*}{ Cagles Mill Lake } & $2 / 13 / 2002$ & Winter & 2.23 & 1.41 & $<0.3$ & 63 & n.d. \\
\hline & $5 / 21 / 2002$ & Spring & 2.34 & 1.51 & $<0.3$ & 65 & n.d. \\
\hline & $8 / 14 / 2002$ & Summer & 0.71 & 0.50 & 0.46 & 70 & 64.8 \\
\hline & $11 / 19 / 2002$ & Fall & 0.95 & 0.71 & $<0.3$ & 75 & n.d. \\
\hline & $3 / 11 / 2003$ & Winter & 3.34 & 2.17 & $<0.3$ & 65 & n.d. \\
\hline & $6 / 17 / 2003$ & Spring & 1.73 & 0.40 & $<0.3$ & 23 & n.d. \\
\hline & $9 / 23 / 2003$ & Summer & 1.83 & 1.31 & 0.32 & 72 & 17.5 \\
\hline & $12 / 16 / 2003$ & Fall & 1.74 & 1.59 & $<0.3$ & 91 & n.d. \\
\hline & $3 / 23 / 2004$ & Winter & 1.31 & 1.31 & $<0.3$ & 100 & n.d. \\
\hline & $8 / 31 / 2004$ & Summer & 1.36 & 0.99 & 0.32 & 73 & 23.5 \\
\hline & $10 / 13 / 2004$ & Fall & 1.17 & 0.85 & 0.12 & 73 & 10.3 \\
\hline & $3 / 4 / 2005$ & Winter & 3.26 & 0.81 & $<0.04$ & 25 & n.d. \\
\hline & $6 / 6 / 2005$ & Spring & 2.18 & 1.22 & 0.14 & 56 & 6.4 \\
\hline & $9 / 2 / 2005$ & Summer & 2.32 & 0.15 & 0.57 & 6 & 24.6 \\
\hline & $12 / 2 / 2005$ & Fall & 1.39 & 0.65 & $<0.04$ & 47 & n.d. \\
\hline & $3 / 3 / 2006$ & Winter & 1.67 & 0.77 & $<0.04$ & 46 & n.d. \\
\hline & $5 / 8 / 2006$ & Spring & 1.94 & 1.00 & 0.06 & 52 & 3.1 \\
\hline & $8 / 21 / 2006$ & Summer & 1.56 & 1.25 & 0.23 & 80 & 14.7 \\
\hline
\end{tabular}

${ }^{1}$ Concentrations in italics were higher than the method detection limit and lower than the reporting limit.

${ }^{2}$ Ratio of particulate Hg to unfiltered Hg, multiplied by 100.

${ }^{3}$ Ratio of unfiltered MeHg to unfiltered $\mathrm{Hg}$, multiplied by 100 . 
Table 1-3. Reservoir-tailwater mercury data.-Continued

[Hg, unfiltered mercury; ng/L, nanogram per liter; PHg, particulate mercury; MeHg, unfiltered methylmercury; <, less than reporting limit listed; n.d., not determined because $\mathrm{PHg}$ or $\mathrm{MeHg}$ was not reported]

\begin{tabular}{|c|c|c|c|c|c|c|c|}
\hline Reservoir & $\begin{array}{c}\text { Sample date } \\
\text { (month/day/ } \\
\text { year) }\end{array}$ & Season & $\underset{(\mathrm{ng} / \mathrm{L})^{1}}{\mathrm{Hg}}$ & $\begin{array}{c}\mathrm{PHg} \\
(\mathrm{ng} / \mathrm{L})^{1}\end{array}$ & $\begin{array}{l}\mathrm{MeHg} \\
(\mathrm{ng} / \mathrm{L})^{1}\end{array}$ & $\begin{array}{c}\text { Ratio of } \\
\text { PHg to } \mathrm{Hg}^{2} \\
\text { (percent) }\end{array}$ & $\begin{array}{c}\text { Ratio of } \\
\text { MeHg to } \mathrm{Hg} \\
{\text { (percent })^{3}}^{\text {pat }}\end{array}$ \\
\hline \multirow[t]{16}{*}{ J.E. Roush Lake } & $4 / 22 / 2002$ & Spring & 5.35 & 4.22 & 0.14 & 79 & 2.6 \\
\hline & $7 / 8 / 2002$ & Summer & 2.06 & 1.31 & 0.24 & 64 & 11.7 \\
\hline & $10 / 21 / 2002$ & Fall & 1.58 & 1.40 & $<0.3$ & 89 & n.d. \\
\hline & $1 / 13 / 2003$ & Winter & 5.82 & 3.61 & 0.26 & 62 & 4.5 \\
\hline & $5 / 19 / 2003$ & Spring & 3.11 & $<0.3$ & $<0.3$ & n.d. & n.d. \\
\hline & $8 / 18 / 2003$ & Summer & 5.50 & 3.92 & 0.66 & 71 & 12.0 \\
\hline & $2 / 23 / 2004$ & Winter & 12.62 & 9.22 & 0.14 & 73 & 1.1 \\
\hline & $8 / 26 / 2004$ & Summer & 1.48 & 1.08 & 0.13 & 73 & 8.8 \\
\hline & $10 / 25 / 2004$ & Fall & 1.24 & 0.89 & 0.08 & 72 & 6.5 \\
\hline & $3 / 7 / 2005$ & Winter & 7.66 & 4.04 & 0.13 & 53 & 1.7 \\
\hline & $6 / 20 / 2005$ & Spring & 2.59 & 0.91 & 0.40 & 35 & 15.4 \\
\hline & $8 / 29 / 2005$ & Summer & 2.67 & 2.21 & 0.04 & 83 & 1.5 \\
\hline & $12 / 5 / 2005$ & Fall & 7.14 & 3.35 & 0.05 & 47 & 0.7 \\
\hline & $3 / 13 / 2006$ & Winter & 15.00 & 9.15 & 0.14 & 61 & 0.9 \\
\hline & $5 / 22 / 2006$ & Spring & 4.37 & 1.91 & 0.12 & 44 & 2.7 \\
\hline & $8 / 28 / 2006$ & Summer & 2.10 & 1.63 & 0.05 & 78 & 2.4 \\
\hline \multirow[t]{15}{*}{ Mississinewa Lake } & $4 / 22 / 2002$ & Spring & 4.96 & 3.32 & $<0.3$ & 67 & n.d. \\
\hline & $7 / 8 / 2002$ & Summer & 2.89 & 2.42 & $<0.3$ & 84 & n.d. \\
\hline & $10 / 21 / 2002$ & Fall & 1.14 & 1.14 & $<0.3$ & 100 & n.d. \\
\hline & $5 / 19 / 2003$ & Spring & 5.13 & 2.97 & $<0.3$ & 58 & n.d. \\
\hline & $8 / 18 / 2003$ & Summer & 3.42 & 2.73 & 0.16 & 80 & 4.7 \\
\hline & $2 / 23 / 2004$ & Winter & 6.65 & 4.56 & 0.11 & 69 & 1.7 \\
\hline & $8 / 26 / 2004$ & Summer & 2.38 & 1.39 & 0.16 & 58 & 6.7 \\
\hline & $10 / 25 / 2004$ & Fall & 2.31 & 1.99 & 0.05 & 86 & 2.2 \\
\hline & $3 / 7 / 2005$ & Winter & 1.74 & 0.73 & 0.05 & 42 & 2.9 \\
\hline & $6 / 20 / 2005$ & Spring & 1.12 & 0.44 & 0.18 & 39 & 16.1 \\
\hline & $8 / 29 / 2005$ & Summer & 1.19 & 0.81 & 0.12 & 68 & 10.1 \\
\hline & $12 / 5 / 2005$ & Fall & 3.25 & 1.09 & 0.05 & 34 & 1.5 \\
\hline & $3 / 13 / 2006$ & Winter & 3.39 & 1.63 & 0.06 & 48 & 1.8 \\
\hline & $5 / 22 / 2006$ & Spring & 3.33 & 1.24 & 0.06 & 37 & 1.8 \\
\hline & $8 / 28 / 2006$ & Summer & 1.38 & 0.69 & 0.09 & 50 & 6.5 \\
\hline
\end{tabular}

${ }^{1}$ Concentrations in italics were higher than the method detection limit and lower than the reporting limit.

${ }^{2}$ Ratio of particulate $\mathrm{Hg}$ to unfiltered $\mathrm{Hg}$, multiplied by 100 .

${ }^{3}$ Ratio of unfiltered MeHg to unfiltered $\mathrm{Hg}$, multiplied by 100 . 
Table 1-4. Hydrologic conditions at three Indiana reservoirs.

[ft, elevation in feet (National Geodetic Vertical Datum 1929) at 0600 or $0700 ;{ }^{\circ} \mathrm{C}$, degree Celsius; $\mathrm{ft}^{3} / \mathrm{s}$, cubic feet per second; in., inch in previous 24 hours]

\begin{tabular}{lccccc}
\hline Reservoir & $\begin{array}{c}\text { Date } \\
\text { (month/day/year) }\end{array}$ & $\begin{array}{c}\text { Daily pool } \\
\text { elevation } \\
\text { (ft) }\end{array}$ & $\begin{array}{c}\text { Tailwater } \\
\text { temperature } \\
\left({ }^{\circ} \mathbf{C}\right)\end{array}$ & $\begin{array}{c}\text { Tailwater } \\
\text { discharge } \\
\left(\mathbf{f t}^{3} / \mathbf{s}\right)\end{array}$ & $\begin{array}{c}\text { Precipitation } \\
\text { (in.) }\end{array}$ \\
\hline Brookville Lake & $7 / 13 / 2009$ & 748.17 & 17.1 & 181 & 0 \\
& $7 / 14 / 2009$ & 748.13 & 17.1 & 104 & 0 \\
& $7 / 15 / 2009$ & 748.12 & 16.9 & 72 & 0 \\
& $7 / 16 / 2009$ & 748.12 & 17.0 & 72 & 0 \\
& $7 / 17 / 2009$ & 748.09 & 17.1 & 72 & 0 \\
Monroe Lake & $7 / 6 / 2009$ & 538.33 & 21.7 & 50 & 0 \\
& $7 / 7 / 2009$ & 538.35 & 21.3 & 200 & 0 \\
& $7 / 8 / 2009$ & 538.36 & 20.1 & 200 & 0.43 \\
& $7 / 9 / 2009$ & 538.36 & 20.5 & 200 & 0.18 \\
& $7 / 10 / 2009$ & 538.33 & 20.5 & 200 & 0.13 \\
& $7 / 20 / 2009$ & 537.48 & 26.7 & 200 & 0 \\
& $7 / 21 / 2009$ & 537.43 & 27.2 & 200 & 0 \\
& $7 / 22 / 2009$ & 537.45 & 26.7 & 200 & 1.27 \\
& $7 / 23 / 2009$ & 537.58 & 26.2 & 50 & 1.76 \\
& $7 / 24 / 2009$ & 537.59 & 26.4 & 50 & 0 \\
\hline
\end{tabular}


[m, meter; $\mathrm{Hg}$, mercury; $\mathrm{ng} / \mathrm{L}$, nanogram per liter; whole water, sum of particulate and dissolved (nondetection assumed to be zero); $\mathrm{MeHg}$, methylmercury; $\mu \mathrm{S} / \mathrm{cm} ;$ microsiemens per centimeter; $\mathrm{mg} / \mathrm{L}$, milligram per liter; ${ }^{\circ} \mathrm{C}$, degree Celsius; NRTU, nephelometric turbidity ratio unit; n.a. not applicable (depth-integrated sample); <, less than reporting limit or percentage listed; n.d., not determined because particulate and dissolved MeHg were not detected]

\begin{tabular}{|c|c|c|c|c|c|c|c|c|c|c|c|c|}
\hline \multicolumn{12}{|c|}{ Brookville Lake } & \\
\hline $\begin{array}{l}\text { Sample } \\
\text { ID }\end{array}$ & $\begin{array}{l}\text { Sample } \\
\text { date }\end{array}$ & $\begin{array}{c}\text { Sample } \\
\text { depth } \\
\text { (m) }\end{array}$ & $\begin{array}{l}\text { Particulate } \\
\mathrm{Hg} \text { (ng/L) }\end{array}$ & $\begin{array}{l}\text { Dissolved } \mathrm{Hg} \\
\text { (ng/L) }\end{array}$ & $\begin{array}{c}\text { Whole-water } \\
\mathrm{Hg} \text { (ng/L) }\end{array}$ & $\begin{array}{c}\text { Ratio of } \\
\text { particulate } \mathrm{Hg} \\
\text { to } \mathrm{Hg}^{1}\end{array}$ & $\begin{array}{l}\text { Particulate } \\
\mathrm{MeHg} \text { (ng/L) }\end{array}$ & $\begin{array}{l}\text { Dissolved } \\
\text { MeHg (ng/L) }\end{array}$ & $\begin{array}{l}\text { Whole-water } \\
\text { MeHg (ng/L) }\end{array}$ & $\begin{array}{c}\text { Ratio of } \\
\text { dissolved } \\
\text { MeHg to } \mathrm{Hg}^{2}\end{array}$ & $\begin{array}{c}\text { Ratio of } \\
\text { whole-water } \\
\text { MeHg to } \mathrm{Hg}^{3}\end{array}$ & \\
\hline 1 & $7 / 17 / 2009$ & n.a. & $<0.10$ & 0.31 & 0.31 & $<29$ & $<0.03$ & $<0.04$ & $<0.04$ & n.d. & n.d. & \\
\hline $2 \mathrm{~A}$ & $7 / 13 / 2009$ & 3.05 & 0.16 & 0.60 & 0.76 & 21 & $<0.03$ & $<0.04$ & $<0.04$ & n.d. & n.d. & \\
\hline $2 \mathrm{~B}$ & $7 / 13 / 2009$ & 10.67 & $<0.10$ & 0.43 & 0.33 & $<27$ & $<0.02$ & $<0.04$ & $<0.04$ & n.d. & n.d. & \\
\hline $2 \mathrm{C}$ & $7 / 13 / 2009$ & 22.86 & $<0.10$ & 0.33 & 0.43 & $<21$ & $<0.03$ & $<0.04$ & $<0.04$ & n.d. & n.d. & \\
\hline $3 \mathrm{~A}$ & $7 / 14 / 2009$ & 3.05 & 0.16 & 0.36 & 0.52 & 30 & $<0.03$ & $<0.04$ & $<0.04$ & n.d. & n.d. & \\
\hline $3 \mathrm{~B}$ & $7 / 14 / 2009$ & 12.19 & 0.12 & 0.40 & 0.52 & 24 & $<0.03$ & $<0.04$ & $<0.04$ & n.d. & n.d. & \\
\hline $3 \mathrm{C}$ & $7 / 14 / 2009$ & 22.86 & 0.23 & 0.35 & 0.58 & 39 & $<0.03$ & $<0.04$ & $<0.04$ & n.d. & n.d. & \\
\hline 4 & $7 / 15 / 2009$ & 0.91 & 1.00 & 0.29 & 1.29 & 77 & $<0.03$ & $<0.04$ & $<0.04$ & n.d. & n.d. & \\
\hline $5 \mathrm{~A}$ & $7 / 15 / 2009$ & 6.1 & 0.26 & 0.37 & 0.63 & 42 & $<0.03$ & $<0.04$ & $<0.04$ & n.d. & n.d. & \\
\hline $5 \mathrm{~B}$ & $7 / 15 / 2009$ & 9.14 & 0.19 & 0.37 & 0.56 & 33 & $<0.03$ & $<0.04$ & $<0.04$ & n.d. & n.d. & \\
\hline $6 \mathrm{~A}$ & $7 / 15 / 2009$ & 3.05 & 0.19 & 0.23 & 0.42 & 46 & $<0.03$ & $<0.04$ & $<0.04$ & n.d. & n.d. & \\
\hline $6 \mathrm{~B}$ & $7 / 15 / 2009$ & 6.1 & 0.17 & 0.29 & 0.46 & 37 & $<0.03$ & $<0.04$ & $<0.04$ & n.d. & n.d. & \\
\hline $6 \mathrm{C}$ & $7 / 15 / 2009$ & 12.19 & 0.45 & 0.34 & 0.79 & 57 & $<0.03$ & $<0.04$ & $<0.04$ & n.d. & n.d. & \\
\hline $7 \mathrm{~A}$ & $7 / 16 / 2009$ & 4.57 & 0.21 & 0.31 & 0.52 & 41 & $<0.03$ & $<0.04$ & $<0.04$ & n.d. & n.d. & \\
\hline $7 \mathrm{~B}$ & $7 / 16 / 2009$ & 7.62 & 0.82 & 0.29 & 1.11 & 74 & $<0.02$ & $<0.04$ & $<0.04$ & n.d. & n.d. & \\
\hline 8 & $7 / 16 / 2009$ & 1.22 & 1.57 & 0.34 & 1.91 & 82 & 0.07 & 0.06 & 0.13 & 18 & 7 & \\
\hline $\begin{array}{l}\text { Sample } \\
\text { ID }\end{array}$ & $\begin{array}{c}\mathrm{pH} \\
\text { (standard } \\
\text { unit) }\end{array}$ & $\begin{array}{c}\text { Specific } \\
\text { conductance } \\
(\mu \mathrm{S} / \mathrm{cm})\end{array}$ & $\begin{array}{l}\text { Dissolved } \\
\text { oxygen } \\
\text { (mg/L) }\end{array}$ & $\begin{array}{c}\text { Water } \\
\text { temperature } \\
\left({ }^{\circ} \mathrm{C}\right)\end{array}$ & $\begin{array}{l}\text { Turbidity } \\
\text { (NRTU) }\end{array}$ & $\begin{array}{l}\text { Suspended } \\
\text { sediment } \\
\text { (mg/L) }\end{array}$ & $\begin{array}{l}\text { Dissolved } \\
\text { sulfate } \\
\text { (mg/L) }\end{array}$ & $\begin{array}{c}\text { Particulate } \\
\text { carbon } \\
\text { (mg/L) }\end{array}$ & $\begin{array}{c}\text { Particulate } \\
\text { organic } \\
\text { carbon (mg/L) }\end{array}$ & $\begin{array}{c}\text { Dissolved } \\
\text { organic } \\
\text { carbon (mg/L) }\end{array}$ & $\begin{array}{l}\text { Total particulate } \\
\text { nitrogen } \\
\text { (mg/L) }\end{array}$ & $\begin{array}{c}\text { Seston } \\
\text { chlorophyll a } \\
\text { (mg/L) }\end{array}$ \\
\hline 1 & 7.9 & 479 & 9.3 & 16.9 & 1.5 & $<15$ & 25.5 & 0.2 & 0.2 & 3.2 & 0.03 & 0.001 \\
\hline $2 \mathrm{~A}$ & 8.4 & 423 & 9.5 & 25.2 & 2 & $<15$ & 26.1 & 1.3 & 1.24 & 3.3 & 0.16 & 0.000 \\
\hline $2 \mathrm{~B}$ & 7.7 & 479 & 0.4 & 18.6 & 2 & $<15$ & 26.1 & 0.2 & 0.22 & 3.8 & 0.04 & 0.002 \\
\hline $2 \mathrm{C}$ & 7.7 & 478 & 1.3 & 12.0 & 1 & $<15$ & 25.3 & 0.2 & 0.18 & 3.8 & 0.01 & 0.001 \\
\hline $3 \mathrm{~A}$ & 8.4 & 419 & 10.0 & 25.1 & 3 & $<15$ & 25.6 & 1.4 & 1.42 & 3.4 & 0.17 & 0.002 \\
\hline $3 B$ & 7.5 & 482 & 0.5 & 17.0 & 2 & $<15$ & 25.7 & 3.6 & 3.58 & 3.1 & 0.06 & 0.002 \\
\hline $3 \mathrm{C}$ & 7.6 & 483 & 0.6 & 12.3 & 4 & $<15$ & 25.6 & 0.4 & 0.40 & 3.2 & 0.03 & 0.002 \\
\hline 4 & 8.3 & 416 & 9.1 & 25.3 & 19 & 18 & 25.5 & 2.5 & 2.47 & 3.4 & 0.33 & 0.010 \\
\hline $5 \mathrm{~A}$ & 7.9 & 431 & 5.4 & 24.2 & 7 & $<15$ & 25.6 & 0.6 & 0.60 & 3.4 & 0.08 & 0.001 \\
\hline $5 \mathrm{~B}$ & 7.4 & 480 & 0.4 & 19.8 & 4 & $<15$ & 24.8 & 0.6 & 0.56 & 3.1 & 0.06 & 0.002 \\
\hline $6 \mathrm{~A}$ & 8.2 & 426 & 9.0 & 25.0 & 3 & $<15$ & 25.6 & 1.6 & 1.60 & 3.5 & 0.22 & 0.004 \\
\hline $6 \mathrm{~B}$ & 7.5 & 445 & 1.6 & 23.7 & 3 & $<15$ & 25.7 & 1 & 0.98 & 3.3 & 0.09 & 0.007 \\
\hline $6 \mathrm{C}$ & 7.4 & 496 & 0.4 & 17.0 & 8 & $<15$ & 24.0 & 0.8 & 0.80 & 3.5 & 0.09 & 0.002 \\
\hline $7 \mathrm{~A}$ & 8.2 & 423 & 9.6 & 25.0 & 5 & $<15$ & 25.8 & 1.4 & 1.41 & 3.3 & 0.20 & 0.007 \\
\hline $7 \mathrm{~B}$ & 7.4 & 491 & 0.6 & 26.8 & 15 & $<15$ & 26.2 & 1.4 & 1.41 & 3.3 & 0.21 & 0.012 \\
\hline 8 & 8.1 & 699 & 7.7 & 21.8 & 16 & 19 & 36.8 & 1 & 1.03 & 2.4 & 0.10 & 0.004 \\
\hline
\end{tabular}

Ratio of particulate $\mathrm{Hg}$ to whole-water $\mathrm{Hg}$ concentration, multiplied by 100. For particulate $\mathrm{Hg}$ concentrations $<0.10 \mathrm{ng} / \mathrm{L}$, the ratio was computed with particulate $\mathrm{Hg}$ set to $0.09 \mathrm{ng} / \mathrm{L}$ and the ratio of particulate $\mathrm{Hg}$ to $\mathrm{Hg}$ was determined to be less than the result.

${ }^{2}$ Ratio of dissolved MeHg to dissolved $\mathrm{Hg}$ concentration, multiplied by 100. For dissolved MeHg concentrations $<0.04 \mathrm{ng} / \mathrm{L}$, the ratio was computed with dissolved MeHg set to $0.03 \mathrm{ng} / \mathrm{L}$ and the ratio of dissolved MeHg to $\mathrm{Hg}$ was determined to be less than the result.

Ratio of whole-water MeHg to whole-water Hg concentration, multiplied by 100. 
Table 1-5. Reservoir-pool and tailwater data for mercury, water-quality characteristics, and supplementary constituents. - Continued

$\left[\mathrm{m}\right.$, meter; $\mathrm{Hg}$, mercury; $\mathrm{ng} / \mathrm{L}$, nanogram per liter; whole water, sum of particulate and dissolved (nondetection assumed to be zero); MeHg, methylmercury; $\mu \mathrm{S} / \mathrm{cm}$; microsiemens per centimeter; $\mathrm{mg} / \mathrm{L}$, milligram per liter; ${ }^{\circ} \mathrm{C}$, degree Celsius; NRTU, nephelometric turbidity ratio unit; n.a. not applicable (depth-integrated sample); $<$, less than reporting limit or percentage listed; n.d., not determined because particulate and dissolved MeHg were not detected]

\begin{tabular}{|c|c|c|c|c|c|c|c|c|c|c|c|c|}
\hline \multicolumn{12}{|c|}{ Monroe Lake } & \\
\hline $\begin{array}{l}\text { Sample } \\
\text { ID }\end{array}$ & $\begin{array}{l}\text { Sample } \\
\text { date }\end{array}$ & $\begin{array}{c}\text { Sample } \\
\text { depth } \\
(\mathrm{m})\end{array}$ & $\begin{array}{c}\text { Particulate } \\
\mathrm{Hg} \text { (ng/L) }\end{array}$ & $\begin{array}{l}\text { Dissolved } \mathrm{Hg} \\
\text { (ng/L) }\end{array}$ & $\begin{array}{c}\text { Whole-water } \\
\mathrm{Hg} \text { (ng/L) }\end{array}$ & $\begin{array}{c}\text { Ratio of } \\
\text { particulate } \mathrm{Hg} \\
\text { to } \mathrm{Hg}^{1}\end{array}$ & $\begin{array}{l}\text { Particulate } \\
\mathrm{MeHg} \text { (ng/L) }\end{array}$ & $\begin{array}{c}\text { Dissolved } \\
\mathrm{MeHg} \text { (ng/L) }\end{array}$ & $\begin{array}{l}\text { Whole-water } \\
\text { MeHg (ng/L) }\end{array}$ & $\begin{array}{c}\text { Ratio of } \\
\text { dissolved } \\
\text { MeHg to } \mathrm{Hg}^{2} \\
\end{array}$ & $\begin{array}{c}\text { Ratio of } \\
\text { whole-water } \\
\text { MeHg to } \mathrm{Hg}^{3}\end{array}$ & \\
\hline 1 & $7 / 10 / 2009$ & n.a. & 1.06 & 0.86 & 1.92 & 55 & 0.08 & 0.48 & 0.56 & 56 & 29 & \\
\hline $2 \mathrm{~A}$ & $7 / 6 / 2009$ & 3.05 & 0.17 & 0.32 & 0.49 & 35 & $<0.02$ & $<0.04$ & $<0.04$ & n.d. & n.d. & \\
\hline $2 \mathrm{~B}$ & $7 / 6 / 2009$ & 7.01 & 0.69 & 0.55 & 1.24 & 56 & 0.08 & 0.12 & 0.20 & 22 & 16 & \\
\hline $2 \mathrm{C}$ & $7 / 6 / 2009$ & 8.23 & 1.79 & 1.12 & 2.91 & 61 & 0.25 & 0.70 & 0.95 & 63 & 33 & \\
\hline $3 \mathrm{~A}$ & 7/7/2009 & 3.05 & 0.15 & 0.27 & 0.42 & 36 & $<0.03$ & 0.05 & 0.05 & 19 & 12 & \\
\hline 3B & 7/7/2009 & 7.01 & 0.92 & 0.49 & 1.41 & 65 & 0.11 & 0.12 & 0.23 & 24 & 16 & \\
\hline $3 \mathrm{C}$ & 7/7/2009 & 7.92 & 3.12 & 1.10 & 4.22 & 74 & 0.49 & 0.70 & 1.19 & 64 & 28 & \\
\hline $4 \mathrm{~A}$ & 7/7/2009 & 3.05 & 0.18 & 0.30 & 0.48 & 37 & $<0.03$ & $<0.04$ & $<0.04$ & n.d. & n.d. & \\
\hline 4B & 7/7/2009 & 5.49 & 0.30 & 0.28 & 0.58 & 51 & 0.03 & $<0.04$ & 0.03 & $<11$ & 5 & \\
\hline $4 \mathrm{C}$ & 7/7/2009 & 7.92 & 3.47 & 1.37 & 4.84 & 72 & 0.57 & 0.80 & 1.37 & 58 & 28 & \\
\hline $5 \mathrm{~A}$ & 7/8/2009 & 4.57 & 0.23 & 0.52 & 0.75 & 30 & 0.06 & $<0.04$ & 0.06 & $<6$ & 9 & \\
\hline $5 \mathrm{~B}$ & $7 / 8 / 2009$ & 10.67 & 2.23 & 1.26 & 3.49 & 64 & 0.55 & 0.73 & 1.28 & 58 & 37 & \\
\hline 6 & $7 / 8 / 2009$ & 1.22 & 0.25 & 0.47 & 0.72 & 35 & $<0.03$ & $<0.04$ & $<0.04$ & n.d. & n.d. & \\
\hline $7 \mathrm{~A}$ & 7/9/2009 & 3.05 & 0.85 & 0.46 & 1.31 & 65 & 0.19 & $<0.04$ & 0.19 & $<7$ & 14 & \\
\hline 7B & 7/9/2009 & 7.62 & 1.31 & 0.81 & 2.13 & 62 & $<0.03$ & 0.16 & 0.16 & 20 & 8 & \\
\hline 8 & 7/9/2009 & 0.30 & 1.41 & 0.66 & 2.07 & 68 & 0.06 & $<0.04$ & 0.06 & $<5$ & 3 & \\
\hline 9 & $7 / 9 / 2009$ & 0.46 & 2.18 & 0.57 & 2.75 & 79 & $<0.03$ & 0.06 & 0.06 & 11 & 2 & \\
\hline $\begin{array}{l}\text { Sample } \\
\text { ID }\end{array}$ & $\begin{array}{c}\mathrm{pH} \\
\text { (standard } \\
\text { unit) }\end{array}$ & $\begin{array}{c}\text { Specific } \\
\text { conductance } \\
(\mu \mathrm{S} / \mathrm{cm})\end{array}$ & $\begin{array}{c}\text { Dissolved } \\
\text { oxygen } \\
\text { (mg/L) } \\
\end{array}$ & $\begin{array}{c}\text { Water } \\
\text { temperature } \\
\left({ }^{\circ} \mathrm{C}\right) \\
\end{array}$ & $\begin{array}{l}\text { Turbidity } \\
\text { (NRTU) }\end{array}$ & $\begin{array}{c}\text { Suspended } \\
\text { sediment } \\
\text { (mg/L) }\end{array}$ & $\begin{array}{l}\text { Dissolved } \\
\text { sulfate } \\
\text { (mg/L) } \\
\end{array}$ & $\begin{array}{c}\text { Particulate } \\
\text { carbon } \\
(\mathrm{mg} / \mathrm{L})\end{array}$ & $\begin{array}{c}\text { Particulate } \\
\text { organic } \\
\text { carbon (mg/L) }\end{array}$ & $\begin{array}{c}\text { Dissolved } \\
\text { organic } \\
\text { carbon (mg/L) }\end{array}$ & $\begin{array}{c}\text { Total particulate } \\
\text { nitrogen } \\
\text { (mg/L) }\end{array}$ & $\begin{array}{c}\text { Seston } \\
\text { chlorophyll } a \\
(\mathrm{mg} / \mathrm{L})\end{array}$ \\
\hline 1 & 6.8 & 129 & 5.9 & 21.3 & 13 & $<15$ & 14.8 & 1.1 & 1.10 & 3.8 & 0.15 & 0.017 \\
\hline $2 \mathrm{~A}$ & 7.5 & 116 & 7.6 & 25.0 & 2 & $<15$ & 18.2 & 0.6 & 0.60 & 3.3 & 0.05 & 0.003 \\
\hline $2 \mathrm{~B}$ & 7.0 & 117 & 7.0 & 24.3 & 5 & $<15$ & 17.5 & 0.9 & 0.89 & 3.7 & 0.12 & 0.022 \\
\hline $2 \mathrm{C}$ & 6.8 & 122 & 4.1 & 19.5 & 14 & $<15$ & 14.8 & 1.0 & 0.98 & 3.9 & 0.13 & 0.017 \\
\hline $3 \mathrm{~A}$ & 7.5 & 116 & 7.5 & 25.1 & 3 & $<15$ & 18.1 & 0.9 & 0.89 & 3.6 & 0.08 & 0.002 \\
\hline $3 \mathrm{~B}$ & 7.0 & 124 & 5.5 & 22.0 & 6 & $<19$ & 17.4 & 0.8 & 0.78 & 3.5 & 0.11 & 0.022 \\
\hline $3 \mathrm{C}$ & 6.6 & 138 & 3.7 & 19.3 & 27 & 38 & 14.0 & 1.6 & 1.54 & 4.4 & 0.18 & 0.018 \\
\hline $4 \mathrm{~A}$ & 7.6 & 116 & 7.4 & 25.0 & 4 & $<15$ & 17.8 & 0.9 & 0.92 & 3.8 & 0.07 & 0.004 \\
\hline $4 B$ & 6.9 & 135 & 5.7 & 22.5 & 5 & $<15$ & 17.6 & 0.6 & 0.58 & 4.1 & 0.05 & 0.004 \\
\hline $4 \mathrm{C}$ & 6.7 & 146 & 4.2 & 20.0 & 40 & 40 & 13.3 & 1.9 & 1.85 & 4.6 & 0.17 & 0.008 \\
\hline $5 \mathrm{~A}$ & 7.4 & 118 & 9.0 & 24.8 & 6 & $<15$ & 17.5 & 0.7 & 0.72 & 3.2 & 0.06 & 0.003 \\
\hline $5 \mathrm{~B}$ & 6.7 & 147 & 3.9 & 18.1 & 31 & 36 & 13.5 & 1.5 & 1.44 & 4.4 & 0.16 & 0.004 \\
\hline 6 & 8.1 & 120 & 10.7 & 26.6 & 6 & $<15$ & 17.6 & 1.2 & 1.14 & 3.5 & 0.14 & 0.004 \\
\hline $7 \mathrm{~A}$ & 7.2 & 129 & 11.0 & 23.9 & 25 & 21 & 16.5 & 1.0 & 1.00 & 3.9 & 0.09 & 0.008 \\
\hline $7 \mathrm{~B}$ & 6.8 & 169 & 8.5 & 21.5 & 27 & 21 & 14.7 & 1.1 & 1.10 & 4.0 & 0.14 & 0.007 \\
\hline 8 & 7.2 & 170 & 12.1 & 24.8 & 50 & 44 & 17.7 & 3.0 & 2.95 & 3.9 & 0.39 & 0.010 \\
\hline 9 & 7.2 & 130 & 15.0 & 27.2 & 30 & 34 & 17.4 & 2.0 & 1.99 & 4.9 & 0.20 & 0.008 \\
\hline
\end{tabular}

${ }^{1}$ Ratio of particulate $\mathrm{Hg}$ to whole-water $\mathrm{Hg}$ concentration, multiplied by 100. For particulate $\mathrm{Hg}$ concentrations $<0.10 \mathrm{ng} / \mathrm{L}$, the ratio was computed with particulate $\mathrm{Hg}$ set to $0.09 \mathrm{ng} / \mathrm{L}$ and the ratio of particulate $\mathrm{Hg}$ to $\mathrm{Hg}$ was determined to be less than the result.

${ }^{2}$ Ratio of dissolved MeHg to dissolved $\mathrm{Hg}$ concentration, multiplied by 100. For dissolved MeHg concentrations $<0.04 \mathrm{ng} / \mathrm{L}$, the ratio was computed with dissolved MeHg set to $0.03 \mathrm{ng} / \mathrm{L}$ and the ratio of dissolved MeHg to Hg was determined to be less than the result. ${ }^{3}$ Ratio of whole-water MeHg to whole-water Hg concentration, multiplied by 100. 
Table 1-5. Reservoir-pool and tailwater data for mercury, water-quality characteristics, and supplementary constituents.-Continued

$\left[\mathrm{m}\right.$, meter; $\mathrm{Hg}$, mercury; $\mathrm{ng} / \mathrm{L}$, nanogram per liter; whole water, sum of particulate and dissolved (nondetection assumed to be zero); $\mathrm{MeHg}$, methylmercury; $\mu \mathrm{S} / \mathrm{cm}$; microsiemens per centimeter; $\mathrm{mg} / \mathrm{L}$, milligram per liter; ${ }^{\circ} \mathrm{C}$, degree Celsius; NRTU, nephelometric turbidity ratio unit; n.a. not applicable (depth-integrated sample); $<$, less than reporting limit or percentage listed; n.d., not determined because particulate and dissolved MeHg were not detected]

\begin{tabular}{|c|c|c|c|c|c|c|c|c|c|c|c|c|}
\hline \multicolumn{12}{|c|}{ Patoka Lake } & \\
\hline $\begin{array}{l}\text { Sample } \\
\text { ID }\end{array}$ & $\begin{array}{l}\text { Sample } \\
\text { date }\end{array}$ & $\begin{array}{l}\text { Sample } \\
\text { depth } \\
\text { (m) }\end{array}$ & $\begin{array}{l}\text { Particulate } \\
\mathrm{Hg} \text { (ng/L) }\end{array}$ & $\begin{array}{l}\text { Dissolved Hg } \\
\text { (ng/L) }\end{array}$ & $\begin{array}{c}\text { Whole-water } \\
\text { Hg (ng/L) }\end{array}$ & $\begin{array}{c}\text { Ratio of } \\
\text { particulate } \mathrm{Hg} \\
\text { to } \mathrm{Hg}^{1}\end{array}$ & $\begin{array}{l}\text { Particulate } \\
\text { MeHg (ng/L) }\end{array}$ & $\begin{array}{c}\text { Dissolved } \\
\text { MeHg (ng/L) }\end{array}$ & $\begin{array}{l}\text { Whole-water } \\
\text { MeHg (ng/L) }\end{array}$ & $\begin{array}{c}\text { Ratio of } \\
\text { dissolved } \\
\text { MeHg to } \mathrm{Hg}^{2}\end{array}$ & $\begin{array}{c}\text { Ratio of } \\
\text { whole-water } \\
\text { MeHg to } \mathrm{Hg}^{3}\end{array}$ & \\
\hline 1 & $7 / 24 / 2009$ & n.a. & 0.33 & 0.19 & 0.52 & 63 & 0.03 & $<0.04$ & 0.03 & $<16$ & 6 & \\
\hline $2 \mathrm{~A}$ & $7 / 20 / 2009$ & 3.05 & 0.18 & 0.53 & 0.71 & 25 & $<0.03$ & $<0.04$ & $<0.03$ & n.d. & n.d. & \\
\hline $2 \mathrm{~B}$ & $7 / 20 / 2009$ & 7.62 & 0.40 & 0.26 & 0.66 & 61 & 0.06 & $<0.04$ & 0.06 & $<12$ & 9 & \\
\hline $2 \mathrm{C}$ & $7 / 20 / 2009$ & 12.19 & 1.10 & 0.49 & 1.59 & 69 & 0.33 & 0.28 & 0.61 & 57 & 38 & \\
\hline $3 \mathrm{~A}$ & $7 / 21 / 2009$ & 3.05 & 0.21 & 0.21 & 0.42 & 49 & $<0.02$ & $<0.04$ & $<0.02$ & n.d. & n.d. & \\
\hline $3 \mathrm{~B}$ & $7 / 21 / 2009$ & 6.10 & 0.22 & 0.21 & 0.43 & 51 & $<0.02$ & $<0.04$ & $<0.02$ & n.d. & n.d. & \\
\hline $3 \mathrm{C}$ & $7 / 21 / 2009$ & 12.19 & 1.45 & 0.45 & 1.90 & 76 & 0.37 & 0.37 & 0.74 & 82 & 39 & \\
\hline $4 \mathrm{~A}$ & $7 / 21 / 2009$ & 3.05 & 0.23 & 0.22 & 0.45 & 52 & $<0.03$ & $<0.04$ & $<0.03$ & n.d. & n.d. & \\
\hline $4 \mathrm{~B}$ & $7 / 21 / 2009$ & 9.14 & 1.02 & 1.07 & 2.09 & 49 & 0.59 & 0.64 & 1.23 & 60 & 59 & \\
\hline 5 & $7 / 21 / 2009$ & 1.52 & 0.28 & 0.29 & 0.57 & 49 & $<0.03$ & $<0.04$ & $<0.03$ & n.d. & n.d. & \\
\hline $6 \mathrm{~A}$ & $7 / 22 / 2009$ & 3.05 & 0.34 & 0.18 & 0.52 & 65 & $<0.02$ & $<0.04$ & $<0.02$ & n.d. & n.d. & \\
\hline $6 \mathrm{~B}$ & $7 / 22 / 2009$ & 7.62 & 0.64 & 0.30 & 0.94 & 68 & 0.16 & 0.12 & 0.28 & 40 & 29 & \\
\hline $6 \mathrm{C}$ & $7 / 22 / 2009$ & 13.72 & 1.30 & 0.71 & 2.01 & 65 & 0.38 & 0.28 & 0.66 & 39 & 33 & \\
\hline 7 & $7 / 22 / 2009$ & 0.61 & 1.33 & 0.25 & 1.58 & 84 & 0.06 & $<0.04$ & 0.06 & $<12$ & 4 & \\
\hline $8 \mathrm{~A}$ & $7 / 22 / 2009$ & 4.57 & 0.69 & 0.17 & 0.86 & 80 & 0.08 & $<0.04$ & 0.08 & $<18$ & 9 & \\
\hline $8 \mathrm{~B}$ & $7 / 22 / 2009$ & 10.67 & 1.50 & 0.55 & 2.05 & 73 & 0.75 & 0.33 & 1.08 & 60 & 53 & \\
\hline 9 & $7 / 23 / 2009$ & 0.91 & 4.47 & 1.04 & 5.51 & 81 & $<0.03$ & $<0.04$ & 0.07 & $<3$ & 1 & \\
\hline 10 & $7 / 23 / 2009$ & 6.10 & 1.54 & 0.29 & 1.83 & 84 & $<0.03$ & 0.04 & 0.16 & 14 & 9 & \\
\hline 11 & $7 / 23 / 2009$ & 6.10 & 1.59 & 0.68 & 2.27 & 70 & $<0.03$ & 0.16 & 0.55 & 24 & 24 & \\
\hline 12 & $7 / 24 / 2009$ & 4.57 & 0.95 & 0.29 & 1.24 & 77 & $<0.03$ & $<0.04$ & $<0.04$ & n.d. & n.d. & \\
\hline $\begin{array}{l}\text { Sample } \\
\text { ID }\end{array}$ & $\begin{array}{c}\mathrm{pH} \\
\text { (standard } \\
\text { unit) }\end{array}$ & $\begin{array}{c}\text { Specific } \\
\text { conductance } \\
(\mu \mathrm{S} / \mathrm{cm})\end{array}$ & $\begin{array}{l}\text { Dissolved } \\
\text { oxygen } \\
\text { (mg/L) }\end{array}$ & $\begin{array}{c}\text { Water } \\
\text { temperature } \\
\left({ }^{\circ} \mathrm{C}\right)\end{array}$ & $\begin{array}{l}\text { Turbidity } \\
\text { (NRTU) }\end{array}$ & $\begin{array}{l}\text { Suspended } \\
\text { sediment } \\
\text { (mg/L) }\end{array}$ & $\begin{array}{l}\text { Dissolved } \\
\text { sulfate } \\
\text { (mg/L) }\end{array}$ & $\begin{array}{l}\text { Particulate } \\
\text { carbon } \\
\text { (mg/L) }\end{array}$ & $\begin{array}{c}\text { Particulate } \\
\text { organic } \\
\text { carbon (mg/L) }\end{array}$ & $\begin{array}{c}\text { Dissolved } \\
\text { organic } \\
\text { carbon (mg/L) }\end{array}$ & $\begin{array}{l}\text { Total particulate } \\
\text { nitrogen } \\
\text { (mg/L) }\end{array}$ & $\begin{array}{c}\text { Seston } \\
\text { chlorophyll a } \\
\text { (mg/L) }\end{array}$ \\
\hline 1 & 7.8 & 170 & 8.0 & 23.7 & 4 & $<15$ & 17.5 & 0.8 & 0.75 & 3.1 & 0.10 & 0.003 \\
\hline $2 \mathrm{~A}$ & 7.9 & 166 & 7.7 & 24.5 & 3 & $<15$ & 17.8 & 0.7 & 0.65 & 2.3 & 0.07 & 0.003 \\
\hline $2 \mathrm{~B}$ & 7.1 & 175 & 0.6 & 18.0 & 4 & $<15$ & 17.5 & 1.0 & 1.00 & 2.6 & 0.20 & 0.008 \\
\hline $2 \mathrm{C}$ & 7.0 & 189 & 0.6 & 13.8 & 9 & 21 & 14.2 & 0.8 & 0.74 & 2.9 & 0.12 & 0.005 \\
\hline $3 \mathrm{~A}$ & 8.2 & 167 & 8.6 & 25.7 & 3 & $<15$ & 18.0 & 0.7 & 0.68 & 3.1 & 0.08 & 0.002 \\
\hline $3 \mathrm{~B}$ & 7.9 & 166 & 5.8 & 24.1 & 8 & $<15$ & 17.9 & 0.3 & 0.32 & 3.1 & 0.05 & 0.003 \\
\hline $3 \mathrm{C}$ & 7.2 & 192 & 0.7 & 13.9 & 7 & 20 & 13.5 & 1.3 & 1.33 & 3.0 & 0.19 & 0.008 \\
\hline $4 \mathrm{~A}$ & 8.3 & 163 & 8.3 & 25.3 & 1 & $<15$ & 18.1 & 0.8 & 0.80 & 3.2 & 0.09 & 0.020 \\
\hline 4B & 6.8 & 185 & 0.6 & 16.0 & 8 & $<15$ & 12.6 & 0.8 & 0.77 & 3.4 & 0.13 & 0.004 \\
\hline 5 & 8.9 & 161 & 9.7 & 25.8 & 5 & $<15$ & 19.1 & 1.5 & 1.48 & 3.1 & 0.21 & 0.007 \\
\hline
\end{tabular}

' Ratio of particulate $\mathrm{Hg}$ to whole-water $\mathrm{Hg}$ concentration, multiplied by 100 . For particulate $\mathrm{Hg}$ concentrations $<0.10 \mathrm{ng} / \mathrm{L}$, the ratio was computed with particulate $\mathrm{Hg}$ set to $0.09 \mathrm{ng} / \mathrm{L}$ and the ratio of particulate $\mathrm{Hg}$ to $\mathrm{Hg}$ was determined to be less than the result.

${ }^{2}$ Ratio of dissolved MeHg to dissolved $\mathrm{Hg}$ concentration, multiplied by 100. For dissolved MeHg concentrations $<0.04 \mathrm{ng} / \mathrm{L}$, the ratio was computed with dissolved MeHg set to $0.03 \mathrm{ng} / \mathrm{L}$ and the ratio of dissolved MeHg to $\mathrm{Hg}$ was determined to be less than the result.

${ }^{3}$ Ratio of whole-water MeHg to whole-water $\mathrm{Hg}$ concentration, multiplied by 100 
Table 1-5. Reservoir-pool and tailwater data for mercury, water-quality characteristics, and supplementary constituents.-Continued

[m, meter; $\mathrm{Hg}$, mercury; ng/L, nanogram per liter; whole water, sum of particulate and dissolved (nondetection assumed to be zero); $\mathrm{MeHg}$, methylmercury; $\mu \mathrm{S} / \mathrm{cm} ;$ microsiemens per centimeter; $\mathrm{mg} / \mathrm{L}$, milligram per liter; ${ }^{\circ} \mathrm{C}$, degree Celsius; NRTU, nephelometric turbidity ratio unit; n.a. not applicable (depth-integrated sample); $<$, less than reporting limit or percentage listed; n.d., not determined because particulate and dissolved MeHg were not detected]

\begin{tabular}{|c|c|c|c|c|c|c|c|c|c|c|c|c|}
\hline \multicolumn{13}{|c|}{ Patoka Lake-continued } \\
\hline $\begin{array}{l}\text { Sample } \\
\text { ID }\end{array}$ & $\begin{array}{c}\text { pH } \\
\text { (standard } \\
\text { unit) }\end{array}$ & $\begin{array}{c}\text { Specific } \\
\text { conductance } \\
(\mu \mathrm{S} / \mathrm{cm})\end{array}$ & $\begin{array}{c}\text { Dissolved } \\
\text { oxygen } \\
\text { (mg/L) }\end{array}$ & $\begin{array}{c}\text { Water } \\
\text { temperature } \\
\left({ }^{\circ} \mathrm{C}\right)\end{array}$ & $\begin{array}{c}\text { Turbidity } \\
\text { (NRTU) }\end{array}$ & $\begin{array}{l}\text { Suspended } \\
\text { sediment } \\
\text { (mg/L) }\end{array}$ & $\begin{array}{l}\text { Dissolved } \\
\text { sulfate } \\
\text { (mg/L) }\end{array}$ & $\begin{array}{l}\text { Particulate } \\
\text { carbon } \\
\text { (mg/L) }\end{array}$ & $\begin{array}{c}\text { Particulate } \\
\text { organic } \\
\text { carbon (mg/L) }\end{array}$ & $\begin{array}{c}\text { Dissolved } \\
\text { organic } \\
\text { carbon (mg/L) }\end{array}$ & $\begin{array}{l}\text { Total particulate } \\
\text { nitrogen } \\
\text { (mg/L) }\end{array}$ & $\begin{array}{c}\text { Seston } \\
\text { chlorophyll a } \\
\text { (mg/L) }\end{array}$ \\
\hline $6 \mathrm{~A}$ & 7.9 & 170 & 7.7 & 24.5 & 4 & $<15$ & 18.1 & 0.7 & 0.68 & 3.0 & 0.07 & 0.002 \\
\hline $6 \mathrm{~B}$ & 7.2 & 178 & 0.7 & 17.9 & 4 & $<15$ & 17.7 & 0.6 & 0.59 & 2.5 & 0.11 & 0.013 \\
\hline $6 \mathrm{C}$ & 7.1 & 199 & 0.7 & 13.7 & 12 & $<30$ & 11.9 & 0.9 & 0.92 & 3.1 & 0.18 & 0.019 \\
\hline 7 & 7.3 & 165 & 6.4 & 25.1 & 17 & 21 & 16.4 & 1.2 & 1.24 & 3.5 & 0.20 & 0.007 \\
\hline $8 \mathrm{~A}$ & 8.0 & 174 & 7.4 & 24.5 & 8 & $<15$ & 15.0 & 1.4 & 1.42 & 2.4 & 0.26 & 0.008 \\
\hline $8 \mathrm{~B}$ & 7.1 & 201 & 0.6 & 15.9 & 10 & 17 & 11.2 & 0.8 & 0.75 & 3.1 & 0.14 & 0.013 \\
\hline 9 & 7.2 & 217 & 5.4 & 21.9 & 88 & 94 & 22.2 & 2.8 & 2.82 & 3.9 & 0.42 & 0.006 \\
\hline 10 & 7.3 & 209 & 0.6 & 22.7 & 31 & 22 & 16.9 & 1.9 & 1.82 & 3.3 & 0.26 & 0.010 \\
\hline 11 & 7.2 & 237 & 0.6 & 21.2 & 21 & 25 & 6.3 & 2.5 & 2.49 & 4.0 & 0.30 & 0.061 \\
\hline 12 & 7.4 & 191 & 4.3 & 23.7 & 11 & $<15$ & 12.9 & 1.2 & 1.20 & 3.8 & 0.13 & 0.005 \\
\hline
\end{tabular}

${ }^{1}$ Ratio of particulate $\mathrm{Hg}$ to whole-water $\mathrm{Hg}$ concentration, multiplied by 100 . For particulate $\mathrm{Hg}$ concentrations $<0.10 \mathrm{ng} / \mathrm{L}$, the ratio was computed with particulate $\mathrm{Hg}$ set to $0.09 \mathrm{ng} / \mathrm{L}$ and the ratio of particulate $\mathrm{Hg}$ to $\mathrm{Hg}$ was determined to be less than the result.

${ }^{2}$ Ratio of dissolved MeHg to dissolved $\mathrm{Hg}$ concentration, multiplied by 100 . For dissolved MeHg concentrations $<0.04 \mathrm{ng} / \mathrm{L}$, the ratio was computed with dissolved MeHg set to $0.03 \mathrm{ng} / \mathrm{L}$ and the ratio of dissolved MeHg to $\mathrm{Hg}$ was determined to be less than the result.

${ }^{3}$ Ratio of whole-water MeHg to whole-water Hg concentration, multiplied by 100. 
Table 1-6. Percentages of land-cover categories in reservoir drainage areas.

$\left[<\right.$, less than; $\mathrm{km}^{2}$, square kilometer $]$

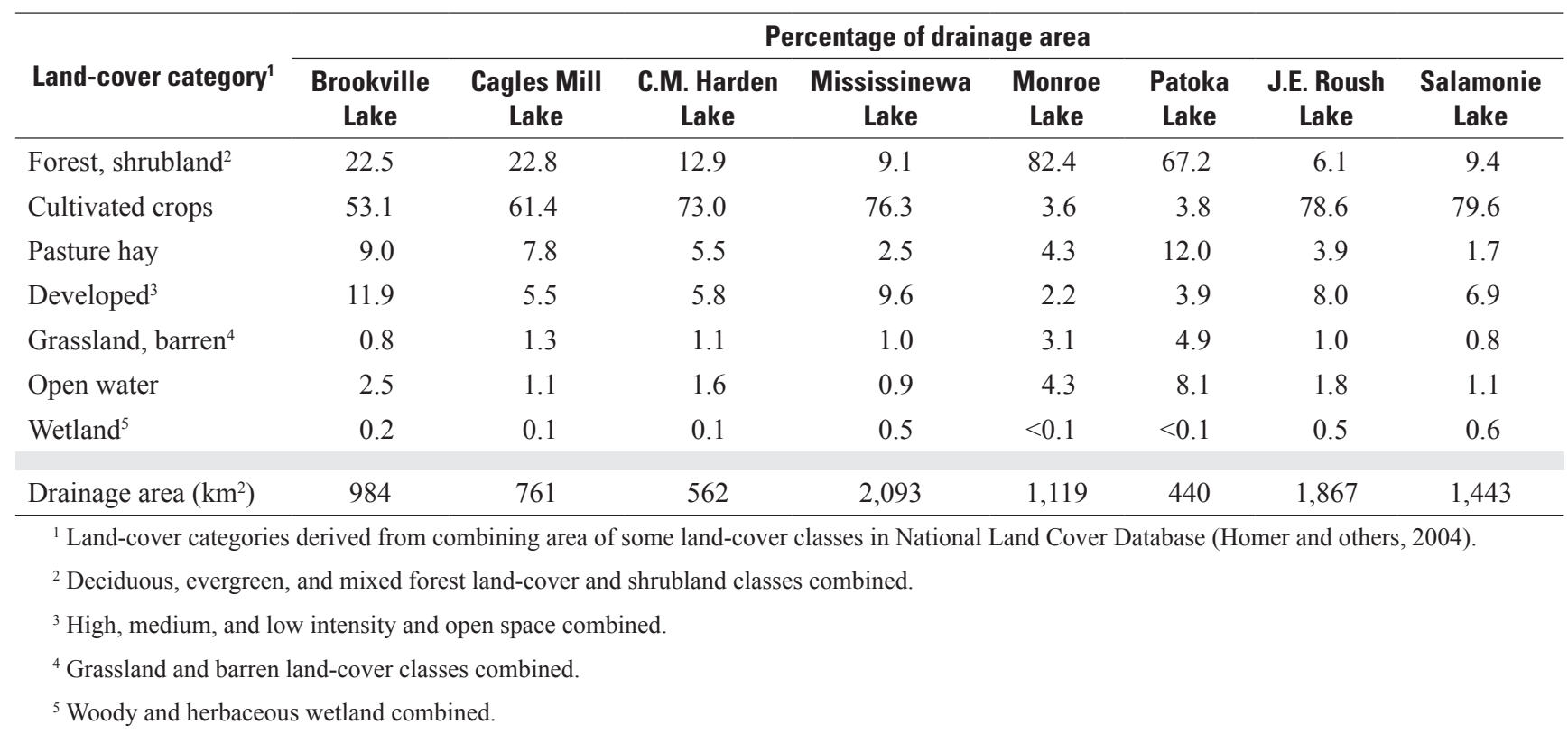

Table 1-7. Mercury wet- and dry-deposition rates and loads to reservoir watersheds in Indiana.

$\left[\mathrm{km}^{2}\right.$, square kilometer; $\mathrm{Hg}$, mercury; $\mathrm{mg} / \mathrm{m}^{2}$, microgram per square meter; g, gram].

\begin{tabular}{|c|c|c|c|c|c|c|c|c|c|}
\hline $\begin{array}{l}\text { Reservoir } \\
\text { watershed }\end{array}$ & $\begin{array}{c}\text { Drainage } \\
\text { area } \\
\left(\mathbf{k m}^{2}\right)\end{array}$ & $\begin{array}{c}\text { Hg wet } \\
\text { deposition } \\
\text { rate }^{1} \\
\left(\mu \mathrm{g} / \mathrm{m}^{2}\right)\end{array}$ & $\begin{array}{l}\text { Hg wet } \\
\text { deposition } \\
\operatorname{load}^{2}(g)\end{array}$ & $\begin{array}{l}\text { Percent } \\
\text { forest } \\
\text { cover }\end{array}$ & $\begin{array}{c}\text { Forest } \\
\text { cover area } \\
\left(\mathbf{k m}^{2}\right)\end{array}$ & $\begin{array}{c}\text { Hg dry } \\
\text { deposition } \\
\text { rate }^{4} \\
\left(\mu \mathrm{g} / \mathrm{m}^{2}\right)\end{array}$ & $\begin{array}{c}\text { Hg dry } \\
\text { deposition } \\
\operatorname{load}^{2}(g)\end{array}$ & $\begin{array}{l}\text { Total Hg } \\
\operatorname{load}^{5}(g)\end{array}$ & $\begin{array}{c}\text { Total } \mathrm{Hg} \\
\text { deposition } \\
\text { rate }^{6} \\
\left(\mu \mathrm{g} / \mathrm{m}^{2}\right)\end{array}$ \\
\hline Brookville Lake & 984 & 11.5 & 11,318 & 22.5 & 221 & 16.0 & 3,543 & 14,861 & 15.1 \\
\hline Cagles Mill Lake & 761 & 11.5 & 8,757 & 22.8 & 173 & 17.4 & 3,014 & 11,771 & 15.5 \\
\hline C.M. Harden Lake & 562 & 11.5 & 6,463 & 12.9 & 73 & 17.4 & 1,265 & 7,728 & 13.8 \\
\hline Monroe Lake & 1,119 & 12.5 & 13,986 & 82.4 & 922 & 16.0 & 14,751 & 28,737 & 25.7 \\
\hline Patoka Lake & 440 & 12.5 & 5,504 & 67.2 & 296 & 16.0 & 4,734 & 10,238 & 23.3 \\
\hline J.E. Roush Lake & 1,867 & 10.5 & 19,607 & 6.1 & 114 & 13.9 & 1,583 & 21,191 & 11.3 \\
\hline Salamonie Lake & 1,443 & 11.5 & 16,590 & 9.4 & 136 & 13.9 & 1,885 & 18,475 & 12.8 \\
\hline
\end{tabular}

${ }^{1}$ Value is the middle of the range, based on mean annual rate for 2001-2006.

${ }^{2}$ Watershed mean annual atmospheric mercury load for 2001-2006 computed as drainage area multiplied by deposition rate.

${ }^{3}$ Forest drainage area computed as drainage area multiplied by percent forest cover from table 1-6 (as decimal).

${ }^{4}$ Dry deposition rate based on 3-year mean litterfall Hg dry deposition rates for 3 sites in Indiana (Risch and others, 2012). Brookville, Monroe, and Patoka are based on IN21 Clifty Falls; Cagles Mill and Harden are based on IN26 Fort Harrison; and Mississinewa, J.E. Roush, and Salamonie are based on IN20 Roush Lake.

${ }^{5}$ Sum of $\mathrm{Hg}$ wet and dry deposition loads.

${ }^{6}$ Total $\mathrm{Hg}$ deposition rate for watershed is total $\mathrm{Hg}$ load divided by drainage area. 
Table 1-8. Reservoir fish-tissue sample and mercury data.

[g, gram; mm, millimeter; Hg conc., mercury concentration; $\mathrm{mg} / \mathrm{kg}$, milligram per kilogram; wt., weight; bold indicates wet weight concentration $>0.30 \mathrm{mg} / \mathrm{kg}$ ]

\begin{tabular}{|c|c|c|c|c|c|c|c|c|c|c|}
\hline Reservoir & $\begin{array}{c}\text { Sample } \\
\text { location }\end{array}$ & $\begin{array}{c}\text { Sample } \\
\text { date }\end{array}$ & $\begin{array}{c}\text { Number } \\
\text { of fish }\end{array}$ & Genus & Species & $\begin{array}{c}\text { Common } \\
\text { name }\end{array}$ & $\begin{array}{c}\text { Sample } \\
\text { type }{ }^{1}\end{array}$ & $\begin{array}{l}\text { Mean fish } \\
\text { weight (g) }\end{array}$ & $\begin{array}{l}\text { Mean fish } \\
\text { length (mm) }\end{array}$ & $\begin{array}{l}\text { Hg conc. (mg/) } \\
\text { kg, wet wt.) }\end{array}$ \\
\hline \multirow[t]{20}{*}{ Brookville Lake } & Dam end & 2002 & 3 & Lepomis & macrochirus & bluegill & 2 & 113 & 180 & 0.067 \\
\hline & Dam end & 2002 & 5 & Cyprinus & carpio & carp & 2 & 1,661 & 512 & 0.230 \\
\hline & Dam end & 2002 & 4 & Ictalurus & punctatus & channel catfish & 1 & 721 & 435 & 0.110 \\
\hline & Dam end & 2002 & 5 & Micropterus & salmoides & largemouth bass & 2 & 663 & 364 & 0.130 \\
\hline & Dam end & 2002 & 5 & Pomoxis & annularis & white crappie & 2 & 207 & 248 & 0.057 \\
\hline & Dam end & 2007 & 4 & Cyprinus & carpio & carp & 2 & 1,382 & 471 & 0.157 \\
\hline & Dam end & 2007 & 1 & Ictalurus & punctatus & channel catfish & 1 & 1,928 & 545 & 0.162 \\
\hline & Dam end & 2007 & 5 & Micropterus & salmoides & largemouth bass & 2 & 795 & 358 & 0.126 \\
\hline & Dam end & 2007 & 3 & Micropterus & dolomieu & smallmouth bass & 2 & 404 & 305 & 0.174 \\
\hline & Dam end & 2007 & 3 & Sander & vitreus & walleye & 2 & 631 & 402 & 0.090 \\
\hline & Quakerstown SRA & 2002 & 5 & Lepomis & macrochirus & bluegill & 2 & 91 & 166 & 0.024 \\
\hline & Quakerstown SRA & 2002 & 5 & Cyprinus & carpio & carp & 2 & 1,350 & 482 & 0.210 \\
\hline & Quakerstown SRA & 2002 & 5 & Micropterus & salmoides & largemouth bass & 2 & 700 & 368 & 0.140 \\
\hline & Quakerstown SRA & 2002 & 2 & Micropterus & salmoides & largemouth bass & 2 & 2,141 & 495 & 0.320 \\
\hline & Quakerstown SRA & 2002 & 5 & Morone & chrysops & white bass & 2 & 707 & 384 & 0.200 \\
\hline & Quakerstown SRA & 2007 & 4 & Pomoxis & nigromaculatus & black crappie & 2 & 271 & 246 & 0.059 \\
\hline & Quakerstown SRA & 2007 & 2 & Cyprinus & carpio & carp & 2 & 1,928 & 521 & 0.118 \\
\hline & Quakerstown SRA & 2007 & 4 & Ictalurus & punctatus & channel catfish & 1 & 1,023 & 443 & 0.091 \\
\hline & Quakerstown SRA & 2007 & 3 & Micropterus & salmoides & largemouth bass & 2 & 602 & 314 & 0.073 \\
\hline & Quakerstown SRA & 2007 & 4 & Morone & chrysops & white bass & 2 & 551 & 329 & 0.119 \\
\hline \multirow[t]{15}{*}{ Cagles Mill Lake } & Near dam & 1996 & 4 & Cyprinus & carpio & carp & 2 & 957 & 417 & 0.119 \\
\hline & Near dam & 1996 & 1 & Micropterus & salmoides & largemouth bass & 2 & 912 & 398 & 0.195 \\
\hline & Near dam & 1996 & 1 & Micropterus & salmoides & largemouth bass & 2 & 564 & 341 & 0.168 \\
\hline & Near dam & 2001 & 10 & Lepomis & macrochirus & bluegill & 2 & 123 & 181 & 0.051 \\
\hline & Near dam & 2001 & 3 & Cyprinus & carpio & carp & 2 & 1,351 & 493 & 0.240 \\
\hline & Near dam & 2001 & 1 & Ictalurus & punctatus & channel catfish & 1 & 1,106 & 521 & 0.130 \\
\hline & Near dam & 2001 & 4 & Micropterus & salmoides & largemouth bass & 2 & 579 & 352 & 0.180 \\
\hline & Near dam & 2001 & 1 & Morone & saxatilis & striped bass & 2 & 255 & 291 & 0.052 \\
\hline & Near dam & 2001 & 2 & Pomoxis & annularis & white crappie & 2 & 226 & 308 & 0.022 \\
\hline & Near dam & 2006 & 4 & Lepomis & macrochirus & bluegill & 2 & 83 & 161 & 0.056 \\
\hline & Near dam & 2006 & 3 & Cyprinus & carpio & carp & 2 & 1,068 & 441 & 0.216 \\
\hline & Near dam & 2006 & 1 & Aplodinotus & grunniens & freshwater drum & 2 & 252 & 299 & 0.261 \\
\hline & Near dam & 2006 & 3 & Micropterus & salmoides & largemouth bass & 2 & 851 & 379 & 0.376 \\
\hline & Near dam & 2006 & 2 & Micropterus & salmoides & largemouth bass & 2 & 323 & 284 & 0.065 \\
\hline & Near dam & 2006 & 6 & Pomoxis & annularis & white crappie & 2 & 113 & 206 & 0.058 \\
\hline
\end{tabular}


Table 1-8. Reservoir fish-tissue sample and mercury data.-Continued

[g, gram; mm, millimeter; Hg conc., mercury concentration; mg/kg, milligram per kilogram; wt., weight; bold indicates wet weight concentration >0.30 mg $/ \mathrm{kg}$ ]

\begin{tabular}{|c|c|c|c|c|c|c|c|c|c|c|}
\hline Reservoir & $\begin{array}{c}\text { Sample } \\
\text { location }\end{array}$ & $\begin{array}{c}\text { Sample } \\
\text { date }\end{array}$ & $\begin{array}{c}\text { Number } \\
\text { of fish }\end{array}$ & Genus & Species & $\begin{array}{c}\text { Common } \\
\text { name }\end{array}$ & $\begin{array}{c}\text { Sample } \\
\text { type }^{1}\end{array}$ & $\begin{array}{l}\text { Mean fish } \\
\text { weight (g) }\end{array}$ & $\begin{array}{l}\text { Mean fish } \\
\text { length }(\mathrm{mm})\end{array}$ & $\begin{array}{l}\text { Hg conc. (mg/) } \\
\text { kg, wet wt.) }\end{array}$ \\
\hline \multirow[t]{22}{*}{ Cecil M. Harden Lake } & Main lake & 1999 & 3 & Lepomis & macrochirus & bluegill & 2 & 60 & 151 & 0.092 \\
\hline & Main lake & 1999 & 3 & Micropterus & salmoides & largemouth bass & 2 & 737 & 375 & 0.270 \\
\hline & Main lake & 1999 & 4 & Micropterus & salmoides & largemouth bass & 2 & 312 & 288 & 0.140 \\
\hline & Main lake & 1999 & 1 & Carpiodes & cyprinus & quillback & 2 & 946 & 420 & 0.160 \\
\hline & Main lake & 2004 & 4 & Pomoxis & nigromaculatus & black crappie & 2 & 159 & 224 & 0.079 \\
\hline & Main lake & 2004 & 9 & Lepomis & macrochirus & bluegill & 2 & 78 & 162 & 0.126 \\
\hline & Main lake & 2004 & 5 & Cyprinus & carpio & carp & 2 & 1,049 & 453 & 0.421 \\
\hline & Main lake & 2004 & 2 & Ictalurus & punctatus & channel catfish & 1 & 755 & 458 & 0.253 \\
\hline & Main lake & 2004 & 1 & Ictalurus & punctatus & channel catfish & 1 & 2,892 & 700 & 0.426 \\
\hline & Main lake & 2004 & 3 & Micropterus & salmoides & largemouth bass & 2 & 1,314 & 433 & 0.350 \\
\hline & Main lake & 2004 & 1 & Morone & saxatilis & striped bass & 2 & 2,693 & 590 & 0.155 \\
\hline & Main lake & 2004 & 2 & Morone & saxatilis & striped bass & 2 & 7,201 & 849 & 0.242 \\
\hline & Main lake & 2004 & 3 & Morone & chrysops & white bass & 2 & 460 & 338 & 0.198 \\
\hline & Main lake & 2004 & 4 & Pomoxis & nigromaculatus & black crappie & 2 & 159 & 224 & 0.079 \\
\hline & Main lake & 2004 & 9 & Lepomis & macrochirus & bluegill & 2 & 78 & 162 & 0.126 \\
\hline & Main lake & 2004 & 5 & Cyprinus & carpio & carp & 2 & 1,049 & 453 & 0.421 \\
\hline & Main lake & 2004 & 2 & Ictalurus & punctatus & channel catfish & 1 & 755 & 458 & 0.253 \\
\hline & Main lake & 2004 & 1 & Ictalurus & punctatus & channel catfish & 1 & 2,892 & 700 & 0.426 \\
\hline & Main lake & 2004 & 3 & Micropterus & salmoides & largemouth bass & 2 & 1,314 & 433 & 0.350 \\
\hline & Main lake & 2004 & 1 & Morone & saxatilis & striped bass & 2 & 2,693 & 590 & 0.155 \\
\hline & Main lake & 2004 & 2 & Morone & saxatilis & striped bass & 2 & 7,201 & 849 & 0.242 \\
\hline & Main lake & 2004 & 3 & Morone & chrysops & white bass & 2 & 460 & 338 & 0.198 \\
\hline
\end{tabular}


Table 1-8. Reservoir fish-tissue sample and mercury data.-Continued

[g, gram; mm, millimeter; Hg conc., mercury concentration; mg/kg, milligram per kilogram; wt., weight; bold indicates wet weight concentration $>0.30 \mathrm{mg} / \mathrm{kg}$ ]

\begin{tabular}{|c|c|c|c|c|c|c|c|c|c|c|}
\hline Reservoir & $\begin{array}{l}\text { Sample } \\
\text { location }\end{array}$ & $\begin{array}{c}\text { Sample } \\
\text { date }\end{array}$ & $\begin{array}{l}\text { Number } \\
\text { of fish }\end{array}$ & Genus & Species & $\begin{array}{c}\text { Common } \\
\text { name }\end{array}$ & $\begin{array}{c}\text { Sample } \\
\text { type }^{1}\end{array}$ & $\begin{array}{l}\text { Mean fish } \\
\text { weight (g) }\end{array}$ & $\begin{array}{l}\text { Mean fish } \\
\text { length (mm) }\end{array}$ & $\begin{array}{l}\text { Hg conc. (mg/) } \\
\text { kg, wet wt.) }\end{array}$ \\
\hline \multirow[t]{28}{*}{ J. Edward Roush Lake } & Main lake & 1998 & 4 & Cyprinus & carpio & carp & 2 & 593 & 347 & 0.065 \\
\hline & Main lake & 1998 & 5 & Cyprinus & carpio & carp & 2 & 1,656 & 494 & 0.149 \\
\hline & Main lake & 1998 & 1 & Cyprinus & carpio & carp & 2 & 2,551 & 577 & 0.179 \\
\hline & Main lake & 1998 & 4 & Micropterus & salmoides & largemouth bass & 2 & 196 & 239 & 0.064 \\
\hline & Main lake & 1998 & 3 & Pomoxis & annularis & white crappie & 2 & 144 & 223 & 0.048 \\
\hline & Main lake & 2004 & 3 & Ictiobus & cyprinellus & bigmouth buffalo & 2 & 1,200 & 420 & 0.067 \\
\hline & Main lake & 2004 & 3 & Cyprinus & carpio & carp & 2 & 2,079 & 533 & 0.211 \\
\hline & Main lake & 2004 & 2 & Ictalurus & punctatus & channel catfish & 1 & 2,850 & 673 & 0.280 \\
\hline & Main lake & 2004 & 2 & Micropterus & salmoides & largemouth bass & 2 & 957 & 411 & 0.442 \\
\hline & Main lake & 2004 & 8 & Micropterus & salmoides & largemouth bass & 2 & 184 & 240 & 0.154 \\
\hline & Main lake & 2004 & 1 & Sander & vitreus & walleye & 2 & 600 & 397 & 0.128 \\
\hline & Main lake & 2004 & 4 & Pomoxis & annularis & white crappie & 2 & 396 & 306 & 0.190 \\
\hline & Main lake & 2004 & 9 & Pomoxis & annularis & white crappie & 2 & 180 & 236 & 0.091 \\
\hline & Main lake & 2004 & 3 & Ictiobus & cyprinellus & bigmouth buffalo & 2 & 1,200 & 420 & 0.067 \\
\hline & Main lake & 2004 & 3 & Cyprinus & carpio & carp & 2 & 2,079 & 533 & 0.211 \\
\hline & Main lake & 2004 & 2 & Ictalurus & punctatus & channel catfish & 1 & 2,850 & 673 & 0.280 \\
\hline & Main lake & 2004 & 2 & Micropterus & salmoides & largemouth bass & 2 & 957 & 411 & 0.442 \\
\hline & Main lake & 2004 & 8 & Micropterus & salmoides & largemouth bass & 2 & 184 & 240 & 0.154 \\
\hline & Main lake & 2004 & 1 & Sander & vitreus & walleye & 2 & 600 & 397 & 0.128 \\
\hline & Main lake & 2004 & 4 & Pomoxis & annularis & white crappie & 2 & 396 & 306 & 0.190 \\
\hline & Main lake & 2004 & 9 & Pomoxis & annularis & white crappie & 2 & 180 & 236 & 0.091 \\
\hline & Main lake & 2008 & 3 & Cyprinus & carpio & carp & 2 & 2,410 & 580 & 0.155 \\
\hline & Main lake & 2008 & 3 & Cyprinus & carpio & carp & 2 & 1,030 & 426 & 0.115 \\
\hline & Main lake & 2008 & 2 & Aplodinotus & grunniens & freshwater drum & 2 & 403 & 330 & 0.121 \\
\hline & Main lake & 2008 & 1 & Aplodinotus & grunniens & freshwater drum & 2 & 1,021 & 457 & 0.272 \\
\hline & Main lake & 2008 & 3 & Micropterus & salmoides & largemouth bass & 2 & 759 & 355 & 0.068 \\
\hline & Main lake & 2008 & 3 & Micropterus & salmoides & largemouth bass & 2 & 394 & 286 & 0.048 \\
\hline & Main lake & 2008 & 5 & Pomoxis & annularis & white crappie & 2 & 399 & 294 & 0.062 \\
\hline
\end{tabular}

${ }^{1}$ Sample type code: $1=$ skin-off fillet; $2=$ skin-on, scaleless fillet. 
Table 1-8. Reservoir fish-tissue sample and mercury data.-Continued

[g, gram; mm, millimeter; Hg conc., mercury concentration; $\mathrm{mg} / \mathrm{kg}$, milligram per kilogram; wt., weight; bold indicates wet weight concentration $>0.30 \mathrm{mg} / \mathrm{kg}$ ]

\begin{tabular}{|c|c|c|c|c|c|c|c|c|c|c|}
\hline Reservoir & $\begin{array}{c}\text { Sample } \\
\text { location }\end{array}$ & $\begin{array}{c}\text { Sample } \\
\text { date }\end{array}$ & $\begin{array}{c}\text { Number } \\
\text { of fish }\end{array}$ & Genus & Species & $\begin{array}{c}\text { Common } \\
\text { name }\end{array}$ & $\begin{array}{c}\text { Sample } \\
\text { type }^{1}\end{array}$ & $\begin{array}{l}\text { Mean fish } \\
\text { weight (g) }\end{array}$ & $\begin{array}{l}\text { Mean fish } \\
\text { length }(\mathrm{mm})\end{array}$ & $\begin{array}{l}\text { Hg conc. (mg/ } \\
\text { kg, wet wt.) }\end{array}$ \\
\hline \multirow[t]{27}{*}{ Mississinewa Lake } & Dam end & 1998 & 3 & Ictalurus & punctatus & channel catfish & 1 & 0 & 443 & 0.071 \\
\hline & Dam end & 1998 & 1 & Micropterus & dolomieu & smallmouth bass & 2 & 516 & 338 & 0.093 \\
\hline & Dam end & 1998 & 2 & Sander & vitreus & walleye & 2 & 289 & 323 & 0.054 \\
\hline & Dam end & 1998 & 3 & Pomoxis & annularis & white crappie & 2 & 0 & 267 & 0.093 \\
\hline & Dam end & 2008 & 6 & Lepomis & macrochirus & bluegill & 2 & 92 & 164 & 0.040 \\
\hline & Dam end & 2008 & 3 & Cурrinus & carpio & carp & 2 & 1,701 & 516 & 0.106 \\
\hline & Dam end & 2008 & 3 & Ictalurus & punctatus & channel catfish & 1 & 1,833 & 565 & 0.126 \\
\hline & Dam end & 2008 & 5 & Micropterus & salmoides & largemouth bass & 2 & 1,134 & 412 & 0.221 \\
\hline & Dam end & 2008 & 5 & Micropterus & salmoides & largemouth bass & 2 & 611 & 346 & 0.097 \\
\hline & Upper end & 1998 & 3 & Micropterus & salmoides & largemouth bass & 2 & 419 & 309 & 0.100 \\
\hline & Upper end & 1998 & 3 & Micropterus & salmoides & largemouth bass & 2 & 901 & 391 & 0.126 \\
\hline & Red Ridge SRA & 2004 & 5 & Сурrinus & carpio & carp & 2 & 1,576 & 484 & 0.259 \\
\hline & Red Ridge SRA & 2004 & 2 & Aplodinotus & grunniens & freshwater drum & 2 & 996 & 432 & 0.322 \\
\hline & Red Ridge SRA & 2004 & 5 & Micropterus & salmoides & largemouth bass & 2 & 639 & 342 & 0.166 \\
\hline & Red Ridge SRA & 2004 & 5 & Micropterus & salmoides & largemouth bass & 2 & 834 & 379 & 0.211 \\
\hline & Red Ridge SRA & 2004 & 6 & Morone & chrysops & white bass & 2 & 254 & 266 & 0.048 \\
\hline & Red Ridge SRA & 2004 & 5 & Cyprinus & carpio & carp & 2 & 1,576 & 484 & 0.259 \\
\hline & Red Ridge SRA & 2004 & 2 & Aplodinotus & grunniens & freshwater drum & 2 & 996 & 432 & 0.322 \\
\hline & Red Ridge SRA & 2004 & 5 & Micropterus & salmoides & largemouth bass & 2 & 639 & 342 & 0.166 \\
\hline & Red Ridge SRA & 2004 & 5 & Micropterus & salmoides & largemouth bass & 2 & 834 & 379 & 0.211 \\
\hline & Red Ridge SRA & 2004 & 6 & Morone & chrysops & white bass & 2 & 254 & 266 & 0.048 \\
\hline & Pearson Mill Public Access & 2008 & 2 & Ictiobus & cyprinellus & bigmouth buffalo & 2 & 1,588 & 482 & 0.035 \\
\hline & Pearson Mill Public Access & 2008 & 5 & Lepomis & macrochirus & bluegill & 2 & 111 & 174 & 0.045 \\
\hline & Pearson Mill Public Access & 2008 & 4 & Cурrinus & carpio & carp & 2 & 1,758 & 504 & 0.139 \\
\hline & Pearson Mill Public Access & 2008 & 5 & Micropterus & salmoides & largemouth bass & 2 & 504 & 336 & 0.104 \\
\hline & Pearson Mill Public Access & 2008 & 4 & Micropterus & salmoides & largemouth bass & 2 & 204 & 243 & 0.038 \\
\hline & Pearson Mill Public Access & 2008 & 5 & Carpiodes & carpio & river carpsucker & 2 & 640 & 372 & 0.110 \\
\hline
\end{tabular}


Table 1-8. Reservoir fish-tissue sample and mercury data.-Continued

[g, gram; mm, millimeter; Hg conc., mercury concentration; $\mathrm{mg} / \mathrm{kg}$, milligram per kilogram; wt., weight; bold indicates wet weight concentration $>0.30 \mathrm{mg} / \mathrm{kg}$

\begin{tabular}{|c|c|c|c|c|c|c|c|c|c|c|}
\hline Reservoir & $\begin{array}{l}\text { Sample } \\
\text { location }\end{array}$ & $\begin{array}{c}\text { Sample } \\
\text { date }\end{array}$ & $\begin{array}{c}\text { Number } \\
\text { of fish }\end{array}$ & Genus & Species & $\begin{array}{c}\text { Common } \\
\text { name }\end{array}$ & $\begin{array}{c}\text { Sample } \\
\text { type }^{1}\end{array}$ & $\begin{array}{l}\text { Mean fish } \\
\text { weight (g) }\end{array}$ & $\begin{array}{c}\text { Mean fish } \\
\text { length }(\mathbf{m m})\end{array}$ & $\begin{array}{l}\text { Hg conc. (mg/ } \\
\text { kg, wet wt.) }\end{array}$ \\
\hline \multirow[t]{39}{*}{ Monroe Lake } & Salt Creek Boat Ramp & 1996 & 2 & Ameiurus & melas & black bullhead & 1 & 400 & 295 & 0.098 \\
\hline & Salt Creek Boat Ramp & 1996 & 2 & Cyprinus & carpio & carp & 2 & 3,363 & 599 & 0.122 \\
\hline & Salt Creek Boat Ramp & 1996 & 3 & Cyprinus & carpio & carp & 2 & 2,204 & 551 & 0.146 \\
\hline & Salt Creek Boat Ramp & 1996 & 2 & Micropterus & salmoides & largemouth bass & 2 & 332 & 296 & 0.480 \\
\hline & Salt Creek Boat Ramp & 2002 & 8 & Lepomis & macrochirus & bluegill & 2 & 97 & 171 & 0.300 \\
\hline & Salt Creek Boat Ramp & 2002 & 3 & Cyprinus & carpio & carp & 2 & 2,457 & 575 & 0.140 \\
\hline & Salt Creek Boat Ramp & 2002 & 2 & Ictalurus & punctatus & channel catfish & 1 & 720 & 442 & 0.190 \\
\hline & Salt Creek Boat Ramp & 2002 & 4 & Micropterus & salmoides & largemouth bass & 2 & 338 & 307 & 0.460 \\
\hline & Salt Creek Boat Ramp & 2002 & 2 & Sander & vitreus & walleye & 2 & 1,120 & 497 & 0.230 \\
\hline & Salt Creek Boat Ramp & 2002 & 1 & Morone & chrysops & white bass & 2 & 380 & 632 & 0.700 \\
\hline & Salt Creek Boat Ramp & 2002 & 1 & Pomoxis & annularis & white crappie & 2 & 784 & 370 & 0.320 \\
\hline & Dam end & 1996 & 5 & Lepomis & macrochirus & bluegill & 2 & 92 & 175 & 0.159 \\
\hline & Dam end & 1996 & 1 & Micropterus & salmoides & largemouth bass & 2 & 780 & 405 & 0.446 \\
\hline & Dam end & 1996 & 3 & Micropterus & salmoides & largemouth bass & 2 & 339 & 301 & 0.415 \\
\hline & Dam end & 1996 & 3 & Micropterus & salmoides & largemouth bass & 2 & 563 & 352 & 0.403 \\
\hline & Dam end & 2002 & 5 & Lepomis & macrochirus & bluegill & 2 & 102 & 177 & 0.120 \\
\hline & Dam end & 2002 & 3 & Cyprinus & carpio & carp & 2 & 1,587 & 497 & 0.130 \\
\hline & Dam end & 2002 & 2 & Micropterus & salmoides & largemouth bass & 2 & 1,077 & 405 & 0.310 \\
\hline & Dam end & 2002 & 9 & Micropterus & salmoides & largemouth bass & 2 & 418 & 324 & 0.320 \\
\hline & Dam end & 2002 & 4 & Lepomis & megalotis & longear sunfish & 2 & 65 & 145 & 0.180 \\
\hline & Dam end & 2002 & 2 & Lepomis & microlophus & redear sunfish & 2 & 121 & 190 & 0.100 \\
\hline & Dam end & 2002 & 1 & Sander & vitreus & walleye & 2 & 3,175 & 675 & 0.910 \\
\hline & Pinegrove SRA & 2007 & 9 & Lepomis & macrochirus & bluegill & 2 & 70 & 155 & 0.130 \\
\hline & Pinegrove SRA & 2007 & 3 & Cyprinus & carpio & carp & 2 & 2,183 & 527 & 0.210 \\
\hline & Pinegrove SRA & 2007 & 1 & Ictalurus & punctatus & channel catfish & 1 & 1,474 & 540 & 0.155 \\
\hline & Pinegrove SRA & 2007 & 3 & Micropterus & salmoides & largemouth bass & 2 & 964 & 375 & 0.355 \\
\hline & Pinegrove SRA & 2007 & 5 & Micropterus & salmoides & largemouth bass & 2 & 414 & 310 & 0.154 \\
\hline & Pinegrove SRA & 2007 & 2 & Sander & vitreus & walleye & 2 & 1,418 & 524 & 0.210 \\
\hline & Pinegrove SRA & 2007 & 2 & Pomoxis & annularis & white crappie & 2 & 432 & 307 & 0.159 \\
\hline & Pinegrove SRA & 2007 & 1 & Morone & chrysopsxsaxatilis & wiper & 2 & 2,155 & 535 & 0.481 \\
\hline & Allens Creek SRA & 2007 & 10 & Lepomis & macrochirus & bluegill & 2 & 87 & 166 & 0.068 \\
\hline & Allens Creek SRA & 2007 & 3 & Cyprinus & carpio & carp & 2 & 2,901 & 582 & 0.116 \\
\hline & Allens Creek SRA & 2007 & 3 & Micropterus & salmoides & largemouth bass & 2 & 2,003 & 480 & 0.556 \\
\hline & Allens Creek SRA & 2007 & 5 & Micropterus & salmoides & largemouth bass & 2 & 526 & 336 & 0.175 \\
\hline & Allens Creek SRA & 2007 & 2 & Sander & vitreus & walleye & 2 & 2,835 & 648 & 0.848 \\
\hline & Allens Creek SRA & 2007 & 3 & Sander & vitreus & walleye & 2 & 1,729 & 554 & 0.698 \\
\hline & Allens Creek SRA & 2007 & 3 & Sander & vitreus & walleye & 2 & 983 & 464 & 0.175 \\
\hline & Allens Creek SRA & 2007 & 4 & Pomoxis & annularis & white crappie & 2 & 163 & 223 & 0.152 \\
\hline & Allens Creek SRA & 2007 & 3 & Morone & mississippiensis & yellow bass & 2 & 155 & 226 & 0.248 \\
\hline
\end{tabular}


Table 1-8. Reservoir fish-tissue sample and mercury data.-Continued

[g, gram; mm, millimeter; Hg conc., mercury concentration; mg $/ \mathrm{kg}$, milligram per kilogram; wt., weight; bold indicates wet weight concentration $>0.30 \mathrm{mg} / \mathrm{kg}$ ]

\begin{tabular}{|c|c|c|c|c|c|c|c|c|c|c|}
\hline Reservoir & $\begin{array}{l}\text { Sample } \\
\text { location }\end{array}$ & $\begin{array}{c}\text { Sample } \\
\text { date }\end{array}$ & $\begin{array}{l}\text { Number } \\
\text { of fish }\end{array}$ & Genus & Species & $\begin{array}{c}\text { Common } \\
\text { name }\end{array}$ & $\begin{array}{c}\text { Sample } \\
\text { type }^{1}\end{array}$ & $\begin{array}{l}\text { Mean fish } \\
\text { weight (g) }\end{array}$ & $\begin{array}{l}\text { Mean fish } \\
\text { length (mm) }\end{array}$ & $\begin{array}{l}\text { Hg conc. (mg//) } \\
\text { kg, wet wt.) }\end{array}$ \\
\hline \multirow[t]{21}{*}{ Patoka Lake } & Lick Fork Branch & 1996 & 1 & Cyprinus & carpio & carp & 2 & 3,490 & 607 & 0.154 \\
\hline & Lick Fork Branch & 1996 & 1 & Cyprinus & carpio & carp & 2 & 829 & 387 & 0.098 \\
\hline & Lick Fork Branch & 1996 & 5 & Micropterus & salmoides & largemouth bass & 2 & 382 & 322 & 0.509 \\
\hline & Lick Fork Branch & 2001 & 8 & Lepomis & macrochirus & bluegill & 2 & 53 & 151 & 0.024 \\
\hline & Lick Fork Branch & 2001 & 3 & Cyprinus & carpio & carp & 2 & 2,136 & 555 & 0.140 \\
\hline & Lick Fork Branch & 2001 & 3 & Micropterus & salmoides & largemouth bass & 2 & 1,247 & 412 & 0.190 \\
\hline & Lick Fork Branch & 2006 & 2 & Cyprinus & carpio & carp & 2 & 2,197 & 534 & 0.158 \\
\hline & Lick Fork Branch & 2006 & 2 & Aplodinotus & grunniens & freshwater drum & 2 & 556 & 361 & 0.060 \\
\hline & Lick Fork Branch & 2006 & 5 & Micropterus & salmoides & largemouth bass & 2 & 869 & 378 & 0.304 \\
\hline & Lick Fork Branch & 2006 & 1 & Micropterus & dolomieu & smallmouth bass & 2 & 808 & 387 & 0.195 \\
\hline & Lick Fork Branch & 2006 & 2 & Minytrema & melanops & spotted sucker & 2 & 782 & 406 & 0.207 \\
\hline & Patoka River, upper end & 1996 & 2 & Micropterus & salmoides & largemouth bass & 2 & 412 & 327 & 0.634 \\
\hline & Patoka River, upper end & 2001 & 8 & Lepomis & macrochirus & bluegill & 2 & 47 & 140 & 0.023 \\
\hline & Patoka River, upper end & 2001 & 3 & Cyprinus & carpio & carp & 2 & 2,315 & 560 & 0.470 \\
\hline & Patoka River, upper end & 2001 & 3 & Micropterus & salmoides & largemouth bass & 2 & 1,493 & 467 & 0.500 \\
\hline & Patoka River, upper end & 2006 & 5 & Lepomis & macrochirus & bluegill & 2 & 58 & 147 & 0.073 \\
\hline & Patoka River, upper end & 2006 & 3 & Cyprinus & carpio & carp & 2 & 2,637 & 602 & 0.198 \\
\hline & Patoka River, upper end & 2006 & 2 & Ictalurus & punctatus & channel catfish & 1 & 3,147 & 636 & 0.221 \\
\hline & Patoka River, upper end & 2006 & 1 & Aplodinotus & grunniens & freshwater drum & 2 & 848 & 400 & 0.098 \\
\hline & Patoka River, upper end & 2006 & 2 & Micropterus & salmoides & largemouth bass & 2 & 933 & 379 & 0.324 \\
\hline & Patoka River, upper end & 2006 & 2 & Micropterus & salmoides & largemouth bass & 2 & 609 & 353 & 0.308 \\
\hline
\end{tabular}


Table 1-8. Reservoir fish-tissue sample and mercury data.-Continued

[g, gram; mm, millimeter; Hg conc., mercury concentration; $\mathrm{mg} / \mathrm{kg}$, milligram per kilogram; wt., weight; bold indicates wet weight concentration $>0.30 \mathrm{mg} / \mathrm{kg}$ ]

\begin{tabular}{|c|c|c|c|c|c|c|c|c|c|c|}
\hline Reservoir & $\begin{array}{c}\text { Sample } \\
\text { location }\end{array}$ & $\begin{array}{c}\text { Sample } \\
\text { date }\end{array}$ & $\begin{array}{l}\text { Number } \\
\text { of fish }\end{array}$ & Genus & Species & $\begin{array}{c}\text { Common } \\
\text { name }\end{array}$ & $\begin{array}{c}\text { Sample } \\
\text { type }^{1}\end{array}$ & $\begin{array}{l}\text { Mean fish } \\
\text { weight (g) }\end{array}$ & $\begin{array}{l}\text { Mean fish } \\
\text { length (mm) }\end{array}$ & $\begin{array}{l}\text { Hg conc. (mg// } \\
\text { kg, wet wt.) }\end{array}$ \\
\hline \multirow[t]{31}{*}{ Salamonie Lake } & Lost Bridge SRA & 2004 & 1 & Cyprinus & carpio & carp & 2 & 1,814 & 501 & 0.245 \\
\hline & Lost Bridge SRA & 2004 & 4 & Ictalurus & punctatus & channel catfish & 1 & 980 & 490 & 0.173 \\
\hline & Lost Bridge SRA & 2004 & 1 & Aplodinotus & grunniens & freshwater drum & 2 & 487 & 344 & 0.195 \\
\hline & Lost Bridge SRA & 2004 & 5 & Micropterus & salmoides & largemouth bass & 2 & 364 & 292 & 0.122 \\
\hline & Lost Bridge SRA & 2004 & 3 & Micropterus & salmoides & largemouth bass & 2 & 1,125 & 410 & 0.395 \\
\hline & Lost Bridge SRA & 2004 & 1 & Pomoxis & annularis & white crappie & 2 & 346 & 374 & 0.100 \\
\hline & Lost Bridge SRA & 2004 & 6 & Pomoxis & annularis & white crappie & 2 & 121 & 213 & 0.141 \\
\hline & Lost Bridge SRA & 2004 & 1 & Cyprinus & carpio & carp & 2 & 1,814 & 501 & 0.245 \\
\hline & Lost Bridge SRA & 2004 & 4 & Ictalurus & punctatus & channel catfish & 1 & 980 & 490 & 0.173 \\
\hline & Lost Bridge SRA & 2004 & 1 & Aplodinotus & grunniens & freshwater drum & 2 & 487 & 344 & 0.195 \\
\hline & Lost Bridge SRA & 2004 & 5 & Micropterus & salmoides & largemouth bass & 2 & 364 & 292 & 0.122 \\
\hline & Lost Bridge SRA & 2004 & 3 & Micropterus & salmoides & largemouth bass & 2 & 1,125 & 410 & 0.395 \\
\hline & Lost Bridge SRA & 2004 & 1 & Pomoxis & annularis & white crappie & 2 & 346 & 374 & 0.100 \\
\hline & Lost Bridge SRA & 2004 & 6 & Pomoxis & annularis & white crappie & 2 & 121 & 213 & 0.141 \\
\hline & Dam end & 1998 & 2 & Lepomis & macrochirus & bluegill & 2 & 140 & 181 & 0.100 \\
\hline & Dam end & 1998 & 4 & Cyprinus & carpio & carp & 2 & 2,297 & 551 & 0.161 \\
\hline & Dam end & 1998 & 4 & Cyprinus & carpio & carp & 2 & 1,595 & 484 & 0.180 \\
\hline & Dam end & 1998 & 3 & Micropterus & salmoides & largemouth bass & 2 & 807 & 385 & 0.212 \\
\hline & Dam end & 1998 & 2 & Micropterus & salmoides & largemouth bass & 2 & 1,021 & 418 & 0.310 \\
\hline & Dam end & 1998 & 2 & Micropterus & salmoides & largemouth bass & 2 & 1,215 & 441 & 0.253 \\
\hline & Dam end & 1998 & 1 & Sander & vitreus & walleye & 2 & 992 & 475 & 0.100 \\
\hline & Dam end & 1998 & 1 & Morone & chrysops & white bass & 2 & 554 & 355 & 0.213 \\
\hline & Dam end & 1998 & 2 & Pomoxis & annularis & white crappie & 2 & 210 & 256 & 0.125 \\
\hline & Dam end & 1998 & 12 & Pomoxis & annularis & white crappie & 2 & 74 & 180 & 0.102 \\
\hline & Lost Bridge SRA & 2008 & 1 & Ictiobus & cyprinellus & bigmouth buffalo & 2 & 5,982 & 654 & 0.116 \\
\hline & Lost Bridge SRA & 2008 & 3 & Cyprinus & carpio & carp & 2 & 3,119 & 607 & 0.169 \\
\hline & Lost Bridge SRA & 2008 & 1 & Aplodinotus & grunniens & freshwater drum & 2 & 1,758 & 490 & 0.336 \\
\hline & Lost Bridge SRA & 2008 & 3 & Aplodinotus & grunniens & freshwater drum & 2 & 243 & 289 & 0.105 \\
\hline & Lost Bridge SRA & 2008 & 6 & Micropterus & salmoides & largemouth bass & 2 & 511 & 325 & 0.055 \\
\hline & Lost Bridge SRA & 2008 & 4 & Micropterus & salmoides & largemouth bass & 2 & 300 & 271 & 0.041 \\
\hline & Lost Bridge SRA & 2008 & 10 & Pomoxis & annularis & white crappie & 2 & 174 & 229 & 0.020 \\
\hline
\end{tabular}

${ }^{1}$ Sample type code: $1=$ =skin-off fillet; $2=$ skin-on, scaleless fillet. 




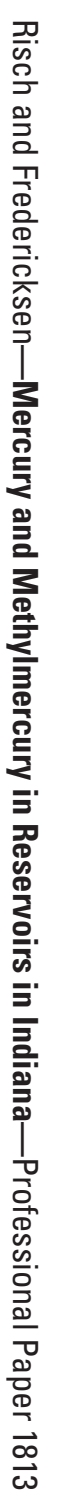

